\title{
Energy Technology Impacts on Agriculture with a Bibliography of Models for Impact Assessment on Crop Ecosystems
}

\author{
E. M. Rupp \\ R. J. Luxmoore \\ D. C. Parzyck
}

ENVIRONMENTAL SCIENCES DIVISION

Publication No. 1278 


\section{DISCLAIMER}

This report was prepared as an account of work sponsored by an agency of the United States Government. Neither the United States Government nor any agency Thereof, nor any of their employees, makes any warranty, express or implied, or assumes any legal liability or responsibility for the accuracy, completeness, or usefulness of any information, apparatus, product, or process disclosed, or represents that its use would not infringe privately owned rights. Reference herein to any specific commercial product, process, or service by trade name, trademark, manufacturer, or otherwise does not necessarily constitute or imply its endorsement, recommendation, or favoring by the United States Government or any agency thereof. The views and opinions of authors expressed herein do not necessarily state or reflect those of the United States Government or any agency thereof. 


\section{DISCLAIMER}

Portions of this document may be illegible in electronic image products. Images are produced from the best available original document. 


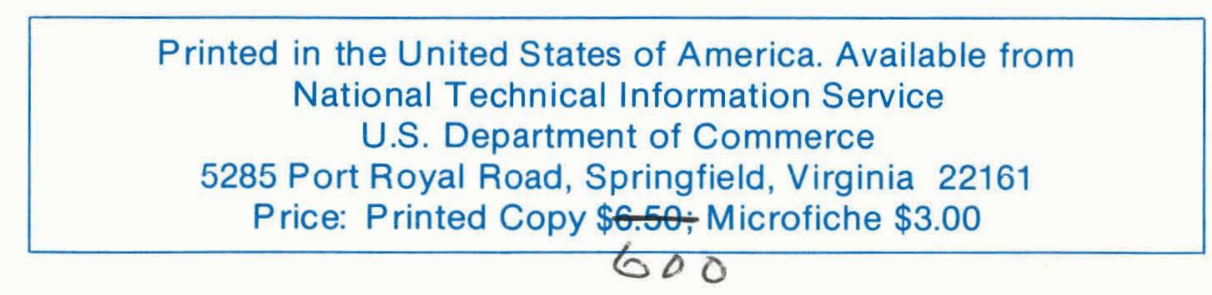

This report was prepared as an account of work sponsored by an agency of the United States Government. Neither the United States Government nor any agency thereof, nor any of their employees, contractors, subcontractors, or their employees, makes any warranty, express or implied, nor assumes any legal liability or responsibility for any third party's use or the results of such use of any information, apparatus, product or process disclosed in this report, nor represents that its use by such third party would not infringe privately owned rights. 
Contract No. W-7.405-eng-26

\section{ENERGY TECHNOLOGY IMPACTS ON AGRICULTURE WITH A BIBLIOGRAPHY OF MODELS FOR IMPACT ASSESSMENT ON CROP ECOSYSTEMS}

E. M. Rupp, 1 R. J. Luxmoore, and D. C. Parzyck 1

ENVIRONMENTAL SCIENCES DIVISION

Publication No. 1278

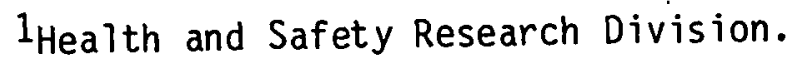

Date Published: September, 1979

NOTICE This document contains information of a preliminary nature. It is subject to revision or correction and therefore does not represent a final report.

OAK RIDGE NATION/L LABORATORY Oak Ridge, Tennessee 37830 operated by UNION CARBIDE CORPORATION for the DEPARTMENT OF ENERGY
This Neport uns price Tpennenred by the Ua prepared as an account of work United States nor the United States Dent. Nefltiet the Energy, nor any of their emplates Department of contractors, subcontractors or thes, nor any of their any warranty, express or implied, er aseloyees, makes liability or responsibilify for the or assumes any legal or usefulness of any information apparys, prodents process disclosed, or represention, apparatus, product or process disclosed, or represents that its use would not
infringe privately owned rights. 
THIS PAGE

\section{WAS INTENTIONALLY LEFT BLANK}




\section{ACKNOWLEDGEMENTS}

The assistance from ORNL information centers with the computer search and the preparation of the computer listings contained in the appendices prepared by Mrs. Penny Myers and Julie Watts were valuable contributions to this work. R. J. 01son prepared Figure 1 as part of the Geoecology project at ORNL. These contributions are greatly appreciated. 
THIS PAGE

\section{WAS INTENTIONALLY LEFT BLANK}


RUPP, E. M.; R. J. LUXMOORE, and D. C. PARZYCK. 1979. Energy technology impacts on agriculture with a bibliography of models for impact assessment on crop ecosystems. ORNL/TM-6694. Oak Ridge National Laboratory, Oak Ridge, Tennessee. $98 \mathrm{pp}$.

Issue: Impact of energy technologies on agricultural crops.

Problem: Severe and chronic effects, beneficial effects, possible unknown effects of energy technologies on agricultural ecosystems.

Purpose: Evaluation of current and projected energy technology impacts on agricultural crops with commentary on a bibliography of computer models for assessment of impäcts on crop ecosys tems.

This report undertakes to evaluate the possible impacts of energy technologies on agriculture and to identify some of the available simulation models that can be used for predictive purposes. An overview of energy technologies and impacts on the environment is presented to provide a framework for the commentary on the models. Coal combustion is shown to have major impacts on the environment and these will continue into the next century according to current Department of Energy projections. Air pollution effects will thus remain as the major impacts on crop ecosystems.

Two hundred reports were evaluated, representing a wide range of models increasing in complexity from mathematical functions (fitted to data) through parametric models (which represent phenomena without describing the mechanisms) to mechanistic models (based on physical, chemical, and physiological principles). Many models were viewed as suitable for adaptation to technology assessment through the incorporation of representative dose-response relationships. It is clear that in many cases available models cannot be taken and directly applied in technology assessment. This fact identifies the need for experienced input from personnel familiar with both modeling and 
dose-response relationships to extend the application of models to technology assessment. Very few models of air pollutant-crop interactions were identified even though there is a considerable data base of pollutant effects on crops. In view of the continuing dependence on coal combustion for energy needs, the development and application of air pollution-crop models should be encouraged. 


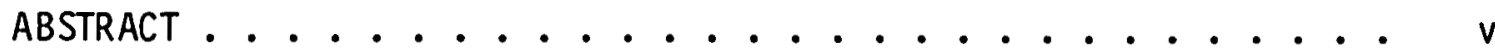

LIST OF TABLES ................... . ix

LIST OF FIGURES . . . . . . . . . . . . . . . xi

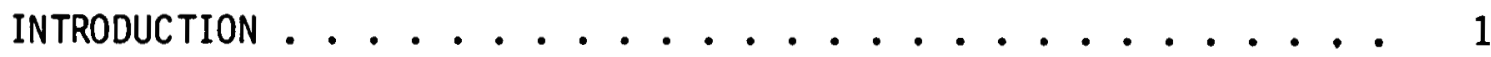

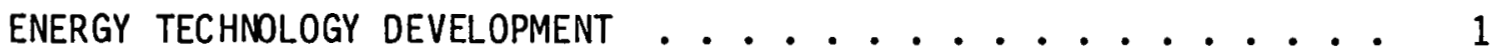

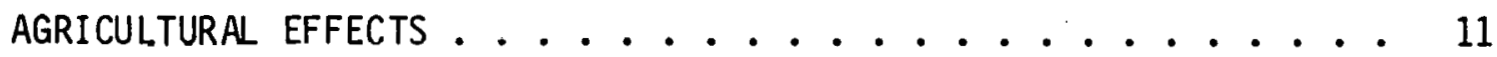

Factors affecting plant response .......... 14

Pollutant injury to plants .............. 17

Dose response relationships ............. 19

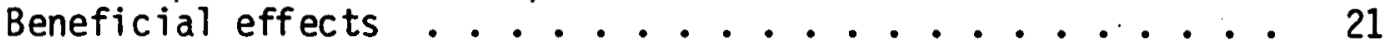

COMMENTARY ON AGRICULTURAL MODELS ................... 22

General comments ................ 23

other model reviews ............... 24

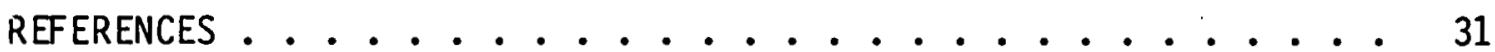
APPENDICES:

A. Agricultural models ............ 35

B. Author index .................. 79

C. Keyword index............... 83 


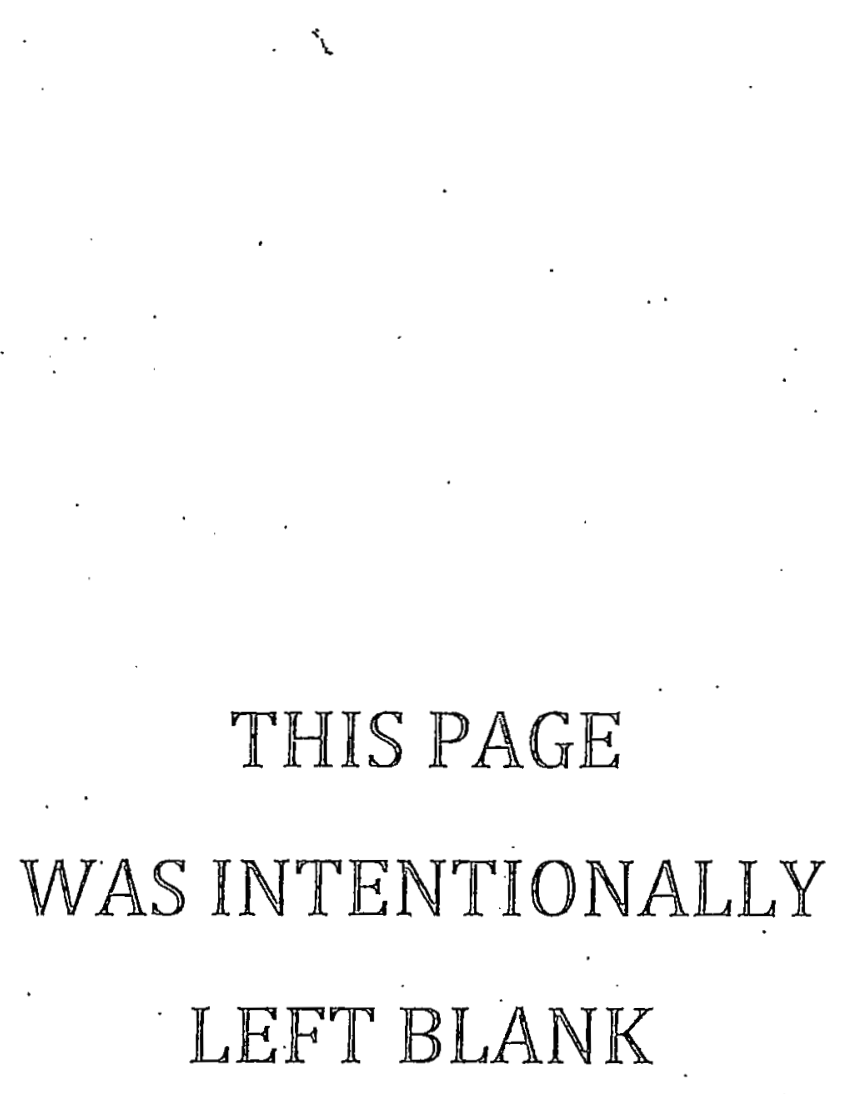




\section{LIST OF TABLES}

Table !

Page

1 Historical and projected estimates of energy consumption by fue 1 type ....................

2 Atmospheric effluents associated with principle energy technology alternatives .............. . 4

3 Projections of energy supplied by new and emerging technology alternatives ............... 6

4 Atmospheric effluents associated with new and emerging technology alternatives ............... . 7

5 Department of Energy regions . . . . . . . . . . 8

6 Generation of electricity by Department of Energy region . . 9

7 Solubilities of selected gases in water at $20^{\circ} \mathrm{C}$. . . . . 15

8 Inhibition of photosynthetic rates of alfalfa by $1-\mathrm{hr}$ treatments with various pollutants and combinations of the pollutants .................. 


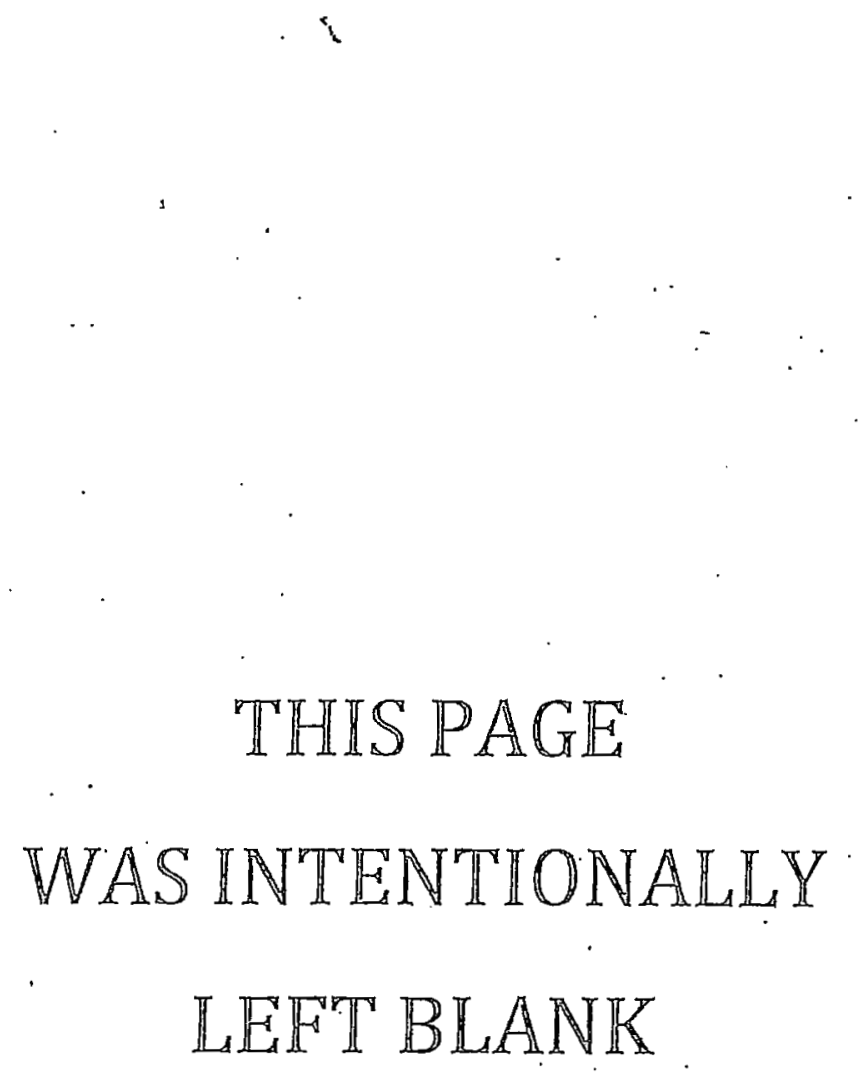




\section{LIST OF FIGURES}

Figure

$\underline{\text { Page }}$

1 Distribution of croplands in the 48 contiguous states of the United States of America (generated from the Geoeco logy Data Base, ORNL) .......... 


\section{INTRODUCTION}

The environmental impacts of energy technology are likely to increase in the next 30 to 40 years with the expansion of energy production by traditional methods (coal combustion, nuclear fission) and alternative sources (geothermal, solar, wind). Some impacts are clearly detrimental and must be reduced in accordance with the clean air and water legislation, whereas other impacts may be chronic (heavy metal deposition) or even beneficial (waste heat utilization) to agricultural crops.

The diverse range of impacts from energy technology development requires careful evaluation for both detrimental and beneficial effects over long and short terms. Computer modeling is one tool that can aid in this important assessment by allowing the evaluation of complex biological and environmental interactions.

This paper is concerned with a bibliography of models of agricultural systems with commentary on their suitability for the environmental assessment of energy technologies, especially those impacts related to the anticipated intensive use of coal in future scenarios. We also present basic information on expected pollutant concentrations and relationships between pollutant concentration and biological responses. Representation of phenomena by simulation modeling is still a developing technique, and although conceptually it can provide the kinds of insights needed for assessment, at the present stage of development, deficiencies in the modeling capabilities and data sources may limit meaningful application.

\section{ENERGY TECHNOLOGY DEVELOPMENT}

In order to put the question of energy technology impacts on agriculture into proper perspective, it is necessary to examine projections of energy development and use. To perform a meaningful analysis, these projections must include a description of energy consumption by fuel type for each region of the country. The relative 
importance of associated effluent releases can then be examined in relation to the agricultural land use within the region.

Estimates of energy consumption by fuel type were taken from the Annual Report to Congress prepared by the Energy Information Administration (1978). This report addressed projections of energy supply and demand for the years 1975, 1985, and 1990 by fuel type. Table 1, based upon information taken from the report for their mid-supply and mid-demand projection, shows a $34 \%$ increase in energy consumption between the years 1975 and 1985 and a 15\% increase in consumption between 1985 and 1990. During the latter 15-year interval, petroleum continues to provide just under $50 \%$ of the total energy consumed.

The role of natural gas decreases during this period from a $28 \%$ share in 1975 to an $18 \%$ share in 1990 . Coal receives increasing emphasis as a fuel alternative in that it is projected to contribute $23 \%$ of the total energy consumed in 1990, an increase of $5 \%$ over the figure for 1975. Similarly, nuclear energy undergoes a $7 \%$ increase in its contribution to the total energy consumed during the period from 1975 to 1990. Hydroelectric power contributes a constant $5 \%$ to the total energy consumed for the period of 1975-1990.

Most of the aforementioned technologies produce effluents which can impact agricultural productivity. Table 2 lists the pollutants specific to the energy technologies presented in Table 1 . in approximately decreasing order according to the magnitude of the effluent release. Coal combustion, petroleum use (primarily gasoline), and natural gas use produce significant amounts of sulfur oxides, nitrogen oxides, particulates, carbon monoxide, carbon dioxide, hydrocarbons, aldehydes, and trace metals. Hydroelectric energy is free of this type of effluent release and nuclear power is associated with low levels of radioactive release that have minor impact on agricultural crops. 
Table 1. Historical and projected est imates of. energy consumption by fuel type from Energy Information Administration (1978)

\begin{tabular}{lccc}
\hline & \multicolumn{3}{c}{ Quadrillion $\left(10^{15}\right) \mathrm{Btu}^{\mathrm{a}}$} \\
\cline { 2 - 4 } & \multicolumn{1}{c}{1975} & 1985 & 1990 \\
\hline Coal & 12.8 & 21.2 & 25.4 \\
Petroleumb & 32.8 & 43.9 & 48.5 \\
Natural gas & 20.0 & 19.1 & 19.3 \\
Hydro-electric & 3.2 & 4.2 & 5.0 \\
Nuclear & 1.8 & $\underline{6.2}$ & $\underline{10.3}$ \\
Total & 70.6 & 94.6 & 108.5 \\
\hline
\end{tabular}

aprojection Series C: mid-supply and mid-demand.

bPrimarily gasoline, but also distillate and residual oil, liquid gas, jet fuel, and other petroleum products. 
Table 2. Atmospheric effluents associated with principle energy technology alternates (from USDOE 1977, USEPA $1973,1974 b, 1975$ )

COAL COMBUSTION

$\mathrm{SO}_{2}$

$\mathrm{NO}_{X}$

Particulates

$\mathrm{CO}$

$\mathrm{CO}_{2}$

Hydrocarbons

Aldehydes

Trace elements ${ }^{a}$

PETROLEUM USE

CO

$\mathrm{CO}_{2}$

Hydrocarbons

$\mathrm{NO}_{\mathrm{X}}$

$\mathrm{SO}_{2}$

Particulates
NATURAL GAS USE

$\mathrm{NO}_{X}$

$\mathrm{CO}$

$\mathrm{CO}_{2}$

Particulates

Hydrucar bunls

$\mathrm{SO}_{2}$

HYDROELECTRIC USE

None

NUCLEAR ENERGY USE

Radionuclidesc

aIncluding nickel; chromium, lead, zinc, mercury, cadmium, and arsenic.

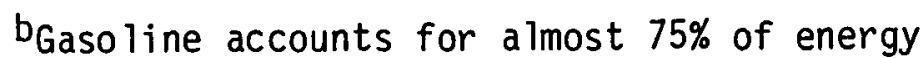
use in this sector.

CIncluding $\mathrm{Xe}-133$, fission products, $\mathrm{Kr}-85$, $\mathrm{H}-3$, and $\mathrm{I}-131$. 
In addition to the technologies cited in Table 2 there are a number of new technologies which are expected to substitute for traditional fossil fuel technologies. However, with an upper bound projection from the Energy Information Administration (1978), these technologies as a group would substitute for less than $2 \%$ of the total demand in 1985 and just over 3\% in 1990 (Tab.le 3). The new technologies would therefore not have a significant impact in the near term. The magnitude of the potential impact of the emerging technologies upon agricultural crops must also be viewed from the standpoint of the effluent releases associated with the various technologies (Table 4). Only the synthetic fuel and geothermal technologies produce effluents with a significant potential impact on agricultural crops. The effluents produced by the synthetic fuel technologies are in many cases the same as those produced by coal combustion and so these technologies will not be addressed separately. Geothermal energy will play a relatively small role in the total energy picture for the near term, and present thinking is that this technology will be primarily developed in California, Idaho, and Oregon (Energy Information Administration 1978).

Just as it is very important to characterize the projections of energy technology mix and the effluents associated with the various technologies, it is equally important to determine the regional distribution of fuel use. Table 5 lists the various states which comprise the ten Department of Energy regions. The projected levels of energy generation by fuel type for the various regions of the country (Table 6) reveal that the greatest levels of coal use are projected for Department of Energy Regions III, IV, and V. The greatest levels of fue 1 oil use are projected for Regions I, II, IV, and IX. Region VI is by far the greatest user of natural gas, and Regions IV and $V$ lead in the use of nuclear fuel for electricity production. Hydroelectric activity is concentrated in Region $X$. 
Table 3. Projections of energy supplied by new and emerging technology alternatives (from Energy Information Administration 1978)

\begin{tabular}{lcc}
\hline & $\frac{\text { Quadrilion }\left(10^{15}\right) \mathrm{Btu}^{\mathrm{a}}}{1985}$ & 1990 \\
\hline Synthetic fuels & 0.40 & 1.35 \\
Geothermal energy & 0.60 & 1.30 \\
Solar energy & 0.15 & 0.29 \\
Wind energy & 0.09 & 0.66 \\
\hline
\end{tabular}

aprojections based on upper bound case assuming major government intervention. 
Table 4. Atmospheric effluents associated with new and emerging technology alternatives (from U.S. Department of Energy, 1977)

\section{SYNETHEIC FUELS}

0il shale<smiles>[AsH2]</smiles>

Hydroc arbons

$\mathrm{NO}_{x}$

$\mathrm{CO}$

$\mathrm{CO}_{2}$

Particulates

Aldehydes
GEOTHERMAL

$\mathrm{CO}_{2}$

Ammonia

Methane

Hydrogen

Hydrogen sulfide

Nitrogen

Argon

SOLAR

HI/LO BTU GAS

$\mathrm{SO}_{\mathrm{x}}$

NO $\mathrm{x}$

Particulates

CO

$\mathrm{CO}_{2}$

Hydrocarbons

Aldehydes

\section{LIQUEFACTION}

NO $x$

$\mathrm{SO}_{\mathrm{x}}$

Particulates

Hydrocarbons
Negligible

WIND ENERGY

None 
Table 5. Department of Energy regions (from Energy Information Administration 1978)

Region I, New England

Connecticut

Maine

Massachusetts

New Hampshire

Rhode Is I and

Vermont

Region II, New York/New Jersey

New Jersey

New York

Region III, Mid Atlantic

Delaware

District of Columbia

Maryland

Pennsylvania

Virginia

West Virginia

Region IV, South At lantic
Alabama
Florida
Georgia
Kentucky
Mississippi
North Carolina
South Carolina
Tennessee

Region V, Midwest

Illino is

Ind $i$ ana

Michigan

Minnesota

Ohio

Wiscons in
Region VI, Southwest

Arkansas

Louisiana

New Mexico

Ok lahoma

Texas

Region VII, Central

Iowa

$K$ ansas

Missour 1

Nebraska

Region VIII, North Central

Colorado

Montana

North Dakota

South Dakota

Utah

Wyoming

Region IX, West

Arizona

California

Hawai i

Nevada
Region $X$, Northwest

Alaska

Idaho

Oregon

Washington 
Table 6. Generation of electricity by Department of Energy region (from Energy Information Administration 1978)

\begin{tabular}{|c|c|c|c|}
\hline & \multicolumn{3}{|c|}{ Quantity $\left(10^{9} \mathrm{kWh}\right)$} \\
\hline$\cdot$ & 1976 & 1985 & 1990 \\
\hline $\begin{array}{l}\text { Region I, New England } \\
\text { Coal } \\
\text { Fuel oil } \\
\text { Gas } \\
\text { Nuclear } \\
\text { Hydro }\end{array}$ & $\begin{array}{r}2.0 \\
43.0 \\
0.3 \\
25.2 \\
5.2\end{array}$ & $\begin{array}{r}22.6 \\
54.7 \\
0.0 \\
23.9 \\
4.4\end{array}$ & $\begin{array}{r}21.4 \\
23.9 \\
0.0 \\
57.3 \\
4.9\end{array}$ \\
\hline $\begin{array}{l}\text { Region II, New York/New Jersey } \\
\text { Coal } \\
\text { Fuel oil } \\
\text { Gas } \\
\text { Nuclear } \\
\text { Hydro }\end{array}$ & $\begin{array}{r}20.2 \\
64.6 \\
1.4 \\
19.5 \\
28.3\end{array}$ & $\begin{array}{r}77.8 \\
59.1 \\
0.1 \\
52.4 \\
36.3\end{array}$ & $\begin{array}{r}75.9 \\
47.0 \\
0.1 \\
98.0 \\
34.0\end{array}$ \\
\hline $\begin{array}{l}\text { Region III, Mid Atlantic } \\
\text { Coal } \\
\text { Fuel oil } \\
\text { Gas } \\
\text { Nuclear } \\
\text { Hydro }\end{array}$ & $\begin{array}{r}182.1 \\
39.6 \\
0.3 \\
30.5 \\
3.8\end{array}$ & $\begin{array}{r}197.8 \\
15.9 \\
2.7 \\
86.0 \\
2.5\end{array}$ & $\begin{array}{r}245.1 \\
15.1 \\
4.2 \\
93.5 \\
2.9\end{array}$ \\
\hline $\begin{array}{l}\text { Region IV, South Atlantic } \\
\text { Coal } \\
\text { Fuel oil } \\
\text { Gas } \\
\text { Nuclear } \\
\text { Hydro }\end{array}$ & $\begin{array}{r}260.5 \\
64.6 \\
15.1 \\
37.4 \\
35.7\end{array}$ & $\begin{array}{r}440.5 \\
102.2 \\
3.3 \\
154.9 \\
41.2\end{array}$ & $\begin{array}{r}587.5 \\
82.2 \\
0.0 \\
267.9 \\
40.5\end{array}$ \\
\hline $\begin{array}{l}\text { Region V, Midwest } \\
\text { Coal } \\
\text { Fuel oil } \\
\text { Gas } \\
\text { Nuclear } \\
\text { Hydro }\end{array}$ & $\begin{array}{r}316.3 \\
17.3 \\
8.0 \\
57.0 \\
3.4\end{array}$ & $\begin{array}{r}425.1 \\
25.5 \\
2.9 \\
131.7 \\
3.7\end{array}$ & $\begin{array}{r}461.0 \\
33.1 \\
1.8 \\
200.1 \\
4.1\end{array}$ \\
\hline $\begin{array}{l}\text { Region VI, Southwest } \\
\text { Coal } \\
\text { Fucl oil } \\
\text { Gas } \\
\text { Nuclear } \\
\text { Hydro }\end{array}$ & $\begin{array}{r}28.6 \\
15.6 \\
213.9 \\
3.9 \\
4.7\end{array}$ & $\begin{array}{r}155.0 \\
10.3 \\
161.8 \\
42.4 \\
9.6\end{array}$ & $\begin{array}{r}214.5 \\
12.1 \\
125.3 \\
77.6 \\
9.2\end{array}$ \\
\hline
\end{tabular}


Table 6 (Continued)

\begin{tabular}{|c|c|c|c|c|}
\hline & & \multicolumn{3}{|c|}{ Quantity $\left(10^{9} \mathrm{kWh}\right)$} \\
\hline & & 1976 & 1985 & 1990 \\
\hline $\begin{array}{l}\text { Region VII, Central } \\
\text { Coal } \\
\text { Fuel } 0 i 1 \\
\text { Gas } \\
\text { Nuclear } \\
\text { Hydro }\end{array}$ & & $\begin{array}{r}60.3 \\
4.7 \\
16.0 \\
8.3 \\
2.7\end{array}$ & $\begin{array}{r}118.0 \\
3.8 \\
4.8 \\
18.0 \\
2.7\end{array}$ & $\begin{array}{r}126.8 \\
4.7 \\
7.1 \\
33.9 \\
2.8\end{array}$ \\
\hline $\begin{array}{l}\text { Region VIII, North Central } \\
\text { Coal } \\
\text { Fuel } 0 \text { il } \\
\text { Gas } \\
\text { Nuclear } \\
\text { Hydro }\end{array}$ & & $\begin{array}{r}40.0 \\
6.5 \\
3.7 \\
0.0 \\
26.1\end{array}$ & $\begin{array}{r}80.9 \\
1.3 \\
0.3 \\
1.9 \\
27.5\end{array}$ & $\begin{array}{r}91.9 \\
1.5 \\
0.3 \\
1.9 \\
28.9\end{array}$ \\
\hline $\begin{array}{l}\text { Region IX, West } \\
\text { Coal } \\
\text { Fuel } 0 i 1 \\
\text { Gas } \\
\text { Nuclear } \\
\text { Hydro }\end{array}$ & & $\begin{array}{r}22.8 \\
69.2 \\
34.1 \\
4.8 \\
32.3\end{array}$ & $\begin{array}{l}28.4 \\
61.2 \\
27.7 \\
35.4 \\
58.0\end{array}$ & $\begin{array}{l}28.0 \\
59.2 \\
29.2 \\
61.1 \\
58.7\end{array}$ \\
\hline $\begin{array}{l}\text { Region } X \text {, Northwest } \\
\text { Coal } \\
\text { Fuel } 0 i 1 \\
\text { Gas } \\
\text { Nuclear } \\
\text { Hydro }\end{array}$ & , & $\begin{array}{r}6.4 \\
0.4 \\
1.5 \\
0.0 \\
140.4\end{array}$ & $\begin{array}{r}6.1 \\
0.3 \\
0.0 \\
19.1 \\
176.4\end{array}$ & $\begin{array}{r}7.3 \\
0.7 \\
0.0 \\
43.6 \\
184.6\end{array}$ \\
\hline
\end{tabular}


While the impacts of effluent release are dependent upon such factors as topography, climate, weather, and the presence of other pollutant sources, it is possible to use information on fuel use and effluent type to characterize the relative severity of impact on agricultural crops for various regions of the country. Figure 1 shows the distribution of cropland among those counties which comprise the 48 contiguous states. The information presented in Fig. 1 was taken from the 1967 National Inventory of Soil and Water Conservation Needs (U.S. Department of Agriculture 1967). The heaviest concentration of cropland occurs in Department of Energy Regions VIII, V, VII, and VI with significantly lesser amounts in each of the remaining six regions. Of these four regions, three (the North Central, Midwest, and Central) will rely on coal for the majority of energy production through the year 1990, according to the projections presented in Table 6 . The one remaining region (the Southwest) has developed a basic reliance on natural gas which will continue through the 1990 timeframe. It is anticipated that coal use will begin to surpass use of natural gas in the period beyond 1985, however. It can be stated, therefore, that crops grown in these four regions will be exposed to significant levels of effluents released by coal combustion facilities that have been shown to have an adverse impact on agriculture.

\section{AGRICULTURAL EFFECTS}

Nearly $60 \%$ of the land in the United States is being used to produce crops (20\%) and livestock (40\%) (Frey et al. 1968), and most of th is land has received some impact from energy technology, considering the global increase in atmospheric $\mathrm{CO}_{2}$ (Baes et al. 1977) and the regional increases in atmospheric $\mathrm{SO}_{2}$ (USEPA 1974a). Considerable empirical data are available on certain aspects of energy technology pollutant effects on vegetation. There are four basic aspects to the evaluation of pollutant effects. 


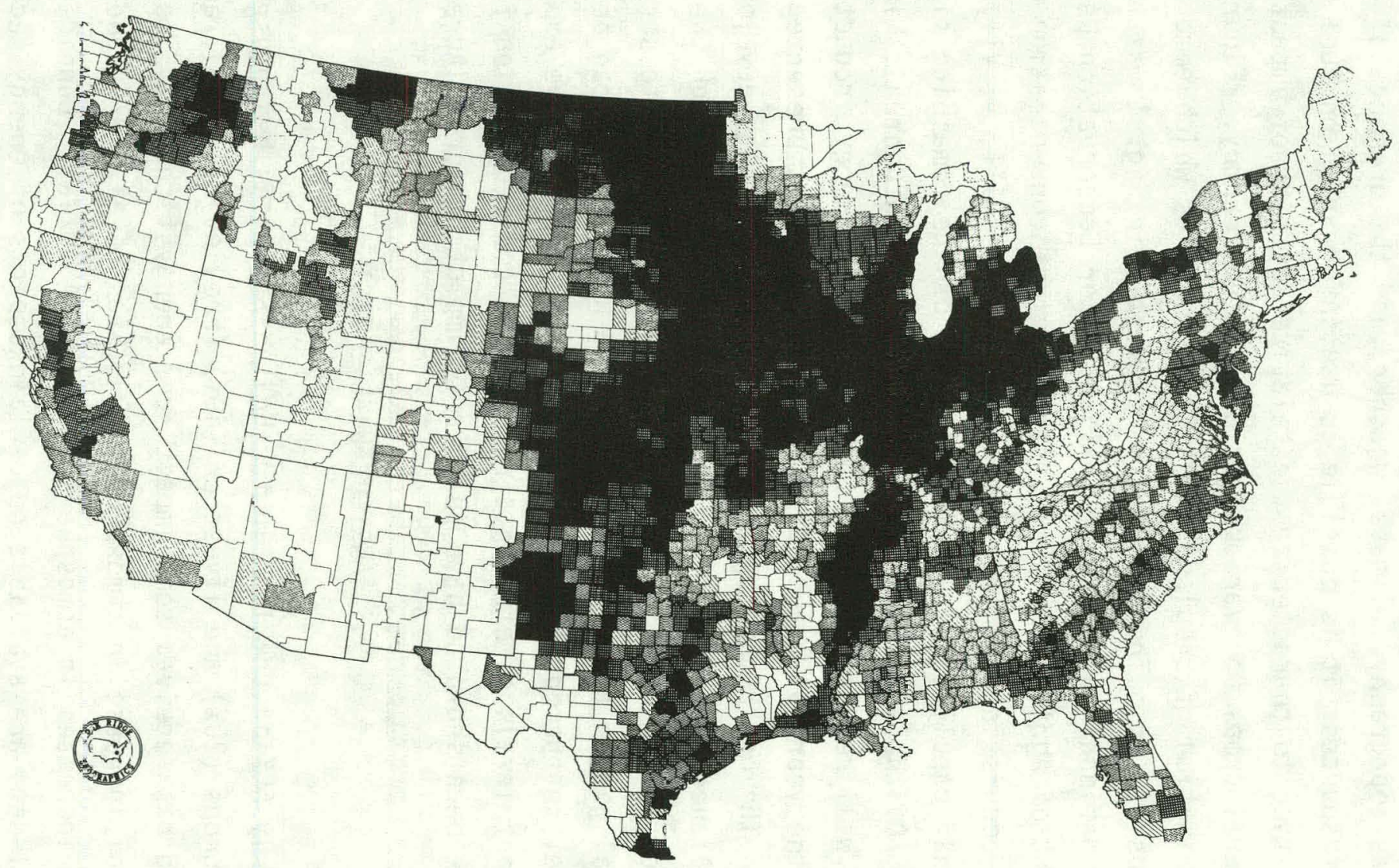

Fig 1. Distrisution of croplands in the 48 conticuous states of the United States of America (generated from the Geoecolojy Jata Base, ORNL). 
(1) Pollutant. Pollutant is a generic word denoting a chemical or group of chemicals which may act alone or synergistically in their effects on receptors. The chemical released from a source may not be the same pollutant near the receptor because complex chemical changes may occur during transport in the atmosphere.

Pollutant composition and concentration will depend on a number of variables such as source characteristics (including type, size, dimension, and location in relation to the location of the vegetation) and the amount of emissions and their effluent velocity and temperature. Plant response to pollutants depends on such properties as chemical composition, physical state, coexisting pollutants, and rate of transfer to the receptor. Consideration must also be given to the concentration of the pollutant near the receptor, its solubility, duration of exposure time, and the frequency distribution of periods of known duration and concentration.

(2) Environment. Environment considerations include meteorological data, climatic factors (such as temperature, relative humidity, light quality and intensity, photoperiod), and such factors as soil temperature, moisture, mineral content, and $\mathrm{CO}_{2}$ concentration.

(3) Receptor. The receptor may be a plant canopy, a whole plant, or a part of a plant (such as a leaf or its roots) or some fine structure of its cells (such as cell membranes, chloroplasts or mitochondria), or it may be some physiological system with in the cells relating to enzyme or hormone control. The receptor may be characterized by its biological organization, species, variety, and genotype, by its structure and relation to its environment under normal conditions, and by its susceptibility to injury by pollutants, age, and state of health, as well as previous exposures.

(4) Event. An event may be described as a change in the character of the receptor in response to a pollutant under the existing environmental conditions. 
Factors Affecting Plant Response

Aside from variations in environmental conditions which influence the sensitivity of plants to phytotoxic air pollutants, there are other considerations of importance, such as the number and condition of stomata, the solubility of pollutants, and the species and individual susceptibility of the plants.

Stomata. Pollutant injury depends on entry through the stomata. Conditions which favor open stomata at the time of exposure predispose the plant to injury. As an example, concentrations of $\mathrm{SO}_{2}$ in the range of 0.1 to $0.5 \mathrm{ppm}$ stimulated stomatal opening (Unsworth et al. 1972). Such stimulation could be particularly relevant in cases of synergism of other pollutants with $\mathrm{SO}_{2}$ because $\mathrm{SO}_{2}$ can st imulate stomatal opening, facilitating the entry of other air pollutants. Water stress causes stomata to close and reduces plant pollutant uptake.

Temperature. Above a critical temperature of $5 \mathrm{C}, \mathrm{SO}_{2}$ injury to plants increases (Wood 1968).

Humidity. Plants are more susceptible to injury as the relative humidity increases (Wood 1968).

Soil moisture. There is an increased resistance of plants to $\mathrm{SO}_{2}$ as the soil moisture reaches the wilting point (Wood 1968).

Solubility of pollutant. Factors which affect absorption relate directly to the accumulation of toxic substances in plants and their subsequent potential injury. In general, the plant uptake rate increases as the solubility of the pollutant increases. A model for gaseous exchange between the atmosphere and a vegetation canopy should include solubility and reaction rate parameters. Highly soluble pollutants could produce high solute levels, depending on the plants' capacity to use, change, or translocate the polluting gas. It would be useful to be able to relate internal pollutant concentrations to external atmospheric concentrations. The solubility of $\mathrm{SO}_{2}$ in water is $228 \mathrm{~g} /$ liter at $0^{\circ} \mathrm{C}$. This is equivalent to dissolving 50 volumes of $\mathrm{SO}_{2}$ in 1 volume of water. Bennett et al. (1973) has tabulated the solubility of several air pollutants (Table 7 ). 
Table 7. Solubilities of selected gases in water at $20^{\circ} \mathrm{C}$ (Bennett et al. 1973)

\begin{tabular}{lc} 
& Solubility \\
Gas & $\begin{array}{c}\text { (m moles gas absorbed per } \\
\mathrm{ml} \mathrm{H}_{2} 0 \mathrm{P}_{\text {gas }}=1 \mathrm{~atm} \text { ) }\end{array}$ \\
\hline $\mathrm{CO}$ & 0.0010 \\
$\mathrm{O}_{2}$ & 0.0014 \\
$\mathrm{NO}_{2}$ & 0.0021 \\
$\mathrm{O}_{2}$ & 0.012 \\
$\mathrm{CO}_{2}$ & 0.039 \\
$\mathrm{Cl}_{2}$ & 0.10 \\
$\mathrm{SO}_{2}$ & 1.6 \\
$\mathrm{HF}^{2}$ & 18 \\
\hline
\end{tabular}


Susceptibility. The most sensitive agricultural plants tend to have succulent leaves and high growth rates. In the case of $\mathrm{SO}_{2}$, susceptible species may be damaged by an 8-hr exposure to concentrations from 0.05 to $0.5 \mathrm{ppm}$. For shorter term exposures ( $30 \mathrm{~min}$ ), the concentration must be raised to 1 to $4 \mathrm{ppm}$ to obtain a plant response, whereas species that are resistant will require $2 \mathrm{ppm}$ for $8 \mathrm{hr}$, or $10 \mathrm{ppm}$ for $30 \mathrm{~min}$. These effects may be greatly altered in the presence of other pollutants (Mudd 1975).

Susceptibility lists of $p l a n t$ responses to pollutants are available but should be used only as a guide. Variations in responses can occur due to differences in geographical location, climate, and plant stage of growth and maturation. For example, alfalfa, barley, endive, and cotton were most sensitive to $\mathrm{SO}_{2}$ in the study of Thomas and Hendricks (1956), with privet being 15 times more tolerant than these sensitive species. Zahn (1961) showed that clover-type fodder plants were most sensitive to $\mathrm{SO}_{2}$, whereas wheat, leafy vegetables (excluding cabbage), beans, strawberries, and roses were moderately sensitive, and root crops and cabbage were least sensitive.

of plants susceptible to $\mathrm{SO}_{2}$ in British Columbia, Canada (based on field observations and fumigation experiments), larch, birch, ninebark, alfalfa, and lettuce were most sensitive, and red cedar, silver maple, spirea, field corn, and asparagus were most tolerant (Katz et al. 1939).

Of cultivated plants and native forest trees susceptible to $\mathrm{SO}_{2}$ (based on field observations), buckwheat, red clover, trembling aspen, jack pine, eastern white pine, white birch, and bracken fern were most sensitive, and cabbage, corn, white spruce, and sugar maple were most tolerant (Dreisinger 1965).

Ten plants that occur commonly throughout the United States were selected and their sensitivity to $\mathrm{SO}_{2}$ determined in fumigation experiments. Chickweed was most sensitive; mustard, annual bluegrass, sunflower, Kentucky bluegrass, pigweed, and cheeseweed were intermediate in their sensitivity; and lambs' quarters, dandelion, and nettleleaf goose-foot, tolerant (Benedict and Breen 1955). 


\section{Pollutant Injury to Plants}

Acute injury in which symptoms of injury are visible

Chlorosis, necrosis, abscission of plant parts, and effects on pigmentation are examples of acute injury with visible symptoms. These symptoms may be produced by high concentrations of $\mathrm{SO}_{2}, \mathrm{PAN}, \mathrm{HF}$, $0_{3}$, ethylene, or combinations of these substances (Taylor 1973). For photographs of $\mathrm{SO}_{2}$ damage to plants, see Jacobson and $\mathrm{Hill}$ (1970).

\section{Invisible injury}

It has been shown that crops with no visible injury may suffer up to $50 \%$ reduction in growth and yield (Schuck 1973). Even though visible injury is not apparent, symptoms of chronic injury (due to repeated exposure to low levels of air pollutants) are manifested by decreased growth, faster aging of foliage, reduction in photosynthes is and in dry weight, reduced leaf size, stem length, root weight, and flower production, as well as a delay in the onset of floral initiation (Feder 1973). In order to evaluate the impact of air pollution on agricultural productivity one must consider both the acute and chronic dose response. The most pervasive air pollutants currently affecting agricultural production are ozone and sulfur dioxide. If present levels in the eastern part of the country should double, major yield reductions of important agronomic crops could result (Heck 1973). The issue is not completely resolved because there are studies that show yield reduction only in association with visible injury ( $\mathrm{Hill}$ and Thomas 1933).

The emission of $\mathrm{SO}_{2}$ and $\mathrm{NO}_{2}$ into the atmosphere from fossil fuel combustion is followed by chemical transformation and acid rainfall, particularly over the eastern United States, with a resulting increase in damage to vegetation. Some effects include (1) reduced photosynthesis; (2) accelerated weathering of protective surface waxes of leaves on both forest and agricultural plant species; (3) increased leaching of nutrients from the leaves of plants and from the soil (most soils have only a finite capacity to buffer acidic leachate); 
(4) increased solubility of toxic metals making them more liable to translocation through the plant; (5) inhibited nodule formation on root systems of legumes making them more susceptible to disease; and (6) interference with mycorrhizae. Since some level of pollutant control is expected to be used in the production of energy, the effects of chronic exposure of plants to low levels of pollutants will probably be more relevant to the determination of impacts from the emissions of power plants than high levels producing acute effects.

Dose-response-symptomology relationships for $\mathrm{SO}_{2}$ as a single pollutant have been well documented. However, most plants grow in open fields and are subjected to exposure to multiple pollutants simultaneously. This may result in more damage than that which would result from the sum of the damage caused by each one acting alone.

The ubiquitous nature of air pollutants makes it a difficult task to pinpoint sources and also to find unpolluted control sites. Foliar injury alone is no longer sufficient to describe plant response to pollutant stress. A reduction in photosynthesis and growth may occur in growing plants before visible symptoms appear, or the rate of photosynthesis may be altered (Mudd and Kozlowski 1975; Bennett et al. 1973). Pollutants may react with cell constituents, disrupting their structural, metabolic, or functional integrity (Mudd and Kozlowski 1975; Wellburn et al. 1972). Among those effects not readily discernible may be those of a physiological or biochemical nature, such as effects on pyrimidines and inactivation of enzyme systems (Mudd and Kozlowski 1975; Ma et al. 1973). Studies at the molecular level are detailed in the book "Responses of Plants to Air Pollution" (Mudd and Kozlowski 1975, pp. 9-22).

Sulfur dioxide has received little mechanistic study by plant physiologists and biochemists, with the result that we cannot yet describe in detail the sequence of events leading to the characteristic response of the plant to this pollutant. Wood (1968) has pointed out that a high degree of correlation between $\mathrm{SO}_{2}$ concentration and severity of vegetation damage, regardless of the level of statistical significance, does not alone establish cause and effect. 
Among the methods that are used to determine the effects of pollutants on plants are inhibition of photosynthesis and crop yield. One of the methods for determining inhibition of photosynthes is is by determination of $\mathrm{CO}_{2}$ and $\mathrm{O}_{2}$ exchange rates of plants. Change in net $\mathrm{CO}_{2}$ assimilation and respiration can be sensitive indicators of pollutant effects on the productivity of plants (Daines 1968). Bennett and Hill (1974) present some responses of alfalfa to common air pollutants (Table 8 ).

Dose-Response Relationships

A number of terms can be used to describe the characteristics of a response; threshold is one. According to 0'Gara (1922), however long the exposure time, no damage will occur below a threshold dose, but above that dose, damage can be produced by combinations of concentration and length of exposure time. He used the following equation to describe the conditions for the development of $\mathrm{SO}_{2}$ damage to plants:

$$
\left(C-C_{R}\right) t=K \text {, }
$$

where $C=$ concentration of pollutant, $C_{R}=$ threshold concentration for injury, $t=$ time in hours required to in itiate damage, and $K=$ constant, the threshold dose.

The criterion most publicized is that if the 8-hr concentration of $\mathrm{SO}_{2}$ does not exceed $0.25 \mathrm{ppm}$, injury to vegetation will seldom occur (Linzon 1972). Concentrations of $0.35 \mathrm{ppm}$ for $4 \mathrm{hr}, 0.55 \mathrm{ppm}$ for $2 \mathrm{hr}$, and $0.95 \mathrm{ppm}$ for $1 \mathrm{hr}$ are considered potentially damaging to vegetation. Chronic or acute injury may occur during the growing season at average annual concentrations of $0.03 \mathrm{ppm}$ or over in the vicinity of stationary sources. Fumigation experiments and field surveys support the above criteria (Brisley et al. 1959; Katz et al. 1939; Linzon 1958). 
Table 8. Inhibition of photosynthetic rates of alfalfa by 1-hr treatments with various pollutants and combinations of the pollutants (from Bennett and Hill 1974)

\begin{tabular}{|c|c|c|c|}
\hline Pollutant(s) & $\begin{array}{l}\text { Conc. } \\
\text { (pphm) }\end{array}$ & $n$ & $\overline{\Delta \mathrm{P}}(\% \text { contro } 1)^{\mathrm{a}}$ \\
\hline \multirow[t]{2}{*}{$0_{3}$} & 10 & 5 & $4 \pm 3$ \\
\hline & 20 & 5 & $10 \pm 4$ \\
\hline \multirow[t]{4}{*}{$\mathrm{SO}_{2}$} & 15 & 5 & 0 \\
\hline & 25 & 15 & $2 \pm 1$ \\
\hline & 30 & 5 & $6 \pm 3$ \\
\hline & 50 & 10 & $21 \pm 3$ \\
\hline \multirow[t]{3}{*}{$\mathrm{NO}_{2}$} & 25 & 13 & 0 \\
\hline & 40 & 5 & $2 \pm 2$ \\
\hline & 50 & 5 & $3 \pm 3$ \\
\hline $\mathrm{HF}$ & 3 & 5 & $3 \pm 2$ \\
\hline \multirow{3}{*}{$\mathrm{SO}_{2}+\mathrm{NO}_{2}$} & $(15+15)$ & 5 & 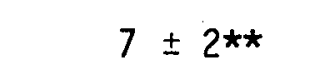 \\
\hline & $(25+25)$ & 1.3 & $9 \pm 2 \star \star$ \\
\hline & $(50+40)$ & 7 & $20+4$ \\
\hline \multirow[t]{2}{*}{$\mathrm{SO}_{2}+\mathrm{O}_{3}$} & $(30+10)$ & 5 & $11 \pm 3$ \\
\hline & $(30+20)$ & 5 & $19 \pm 4$ \\
\hline $\mathrm{SO}_{2}+\mathrm{HF}$ & $(25+3)$ & 5 & $9 \pm 3 *$ \\
\hline $\mathrm{NO}_{2}+\mathrm{HF}$ & $(50+3)$ & 5 & $7 \pm 3$ \\
\hline $\mathrm{NO}_{2}+\mathrm{O}_{3}$ & $(50+10)$ & 3 & $9 \pm 4$ \\
\hline
\end{tabular}

aMean depression $(\overline{\Delta p})$ in $\mathrm{CO}_{2}$ uptake rates induced after 1 -hr exposures, and $95 \%$ confidence interval. (Superscripts $\star \star$ and * denote those significant means at $1 \%$ and $5 \%$ significance levels, respectively, when compared with the sumed depressions determined for the separately applied pollutants at corresponding concentrations.) 
This report is not an exhaustive review of the literature nor a detailed description of all the possible dose-response relationships. Such relationships may be found in the references used in this paper and in the following special references whose authors have reported either their own work or compiled data from the literature.

(1) Sumary of data on exposure of

plants to $\mathrm{SO}_{2}$.

(Wood 1968)

(2) Response of horticultural crops

to $\mathrm{SO}_{2}$ and $\mathrm{O}_{3}$ mixtures. (Reinert et al. 1975)

(3) Plant response to $\mathrm{SO}_{2}$ and $\mathrm{NO}_{2}$. mixtures.

(Re inert et al. 1975)

(4) $\mathrm{Pl}$ ant response to $\mathrm{SO}_{2}$ and $\mathrm{HF}$ mixtures.

(Reinert et al. 1975)

(5) Crop, ornamental, and forest species in which variation in sensitivity to the (Ryder 1973) pollutants named has been observed.

(6) Sensitivity of woody plants to $\mathrm{SO}_{2}$ and (Davis amd Wilhour 1976) photochemical oxidants.

(7) Maximum ranges of annual average $\mathrm{SO}_{2}$ concentrations tolerable to lichens and bryophytes.

\section{Beneficial Effects}

Many products from energy technologies can be used to increase agricultural productivity. Waste heat may be used to heat greenhouses and soil and can also be used to dry agricultural products. Sulfur is an essential element in plant and animal growth, and the $\mathrm{SO}_{2}$ releases from coal combustion facilities may alleviate sulfur deficiency in some grassland and cropping areas. Saline water from cooling towers (blowdown) could be used to irrigate agricultural crops without detrimental effects if careful irrigation management is maintained. It is clear, however, that these benefits are rather specialized and overall energy technology effluents would probably result in degradation of the environment without suitable controls. 
COMMENTARY ON AGRICULTURAL MODELS

The blossoming of simulation modeling from the mid-1960s has produced a large number of models of a diverse range of phenomena in many varied disciplines. Evaluation of these efforts in terms of specific needs or questions can be made through detailed examination of available documentation and model application reports. This survey attempts a more general evaluation in terms of possible model applications for the assessment of any energy technology impacts on agricultural ecosystems. Two hundred references were reviewed from a computer search of the following data bases: EEDB - ERDA Energy Data Base, GRA - Government Reports Announcements, BA - Biningir.al Abstracts, BRI - Biological Research Index, CAIN - National Agricultural Library, and CBALL - Chemical and Biological Activities. Retrospective searches were conducted initially in April 1976 and periodic searches were continued until January 1978 with the following key word matrix:

Group I agriculture, agronomy, irrigation, soil, plant, litter, root, leaf, growth, corn, wheat, soybean, forage.

Group II model, computer simulation, simulation, mathematical, code.

Key words were expanded to include related terms such as crop, stomata, photosynthesis, grass, pasture, cotton, evapotranspiration, water, radiation, and vegetables.

Cross codes - Each reference included in Biological Abstracts is grouped into category and the category given a number. We searched the relevant numbered categories combined with key words in Group I and Group II. The coded numbers themselves were included with Group I.

Code numbers and categories used in this search: 07506P - plant ecology; 51502P - water relations; $51510 \mathrm{P}$ - cell growth and differentiation; 51516P - radiation effects (1ight effects); 51524P apparatus and method for plant physiological studies; 525 - agronomy; and $53008 \mathrm{P}$ - vegetables. 
Search logic - Group I and Group II were combined.

Relevant references were obtained and reviewed. More recent information was obtained through correspondence with several of the well-established modeling groups in the United States and overseas.

This task remains unfinished in view of the continuing development and use of models for agricultural ecosystems. The survey contains information that is predominantly obtained from open literature. The modeling reports published by institutions were reviewed as much as possible. However, there is probably considerable information that was not detected by the computer search mechanism.

other reviews of modeling literature were also examined. These sources, although different in purpose, are outlined in a later section with comments about the relevance of these reviews to the assessment of energy technology impacts in agriculture.

\section{General Comments}

A wide range of models was examined in which the complexity increased from mathematical functions fitted to experimental data, through parametric models that described phenomena without representation of mechanisms to mechanistic models based on physical, chemical, and/or physiological principles. The empirical and parametric models are restricted in their application to situations that closely resemble that for which the model was calibrated. Alternatively, field measurements can be made in a new situation to determine appropriate parameter values. The mechanistic models also require input values for the appropriate soil, plant, animal, or atmospheric properties as required by the mechanisms or processes involved. These latter models can conceptually be applied to most locations, whereas the empirical models are local or at best regional in their range of application.

The model evaluation (Appendix A) contains the full citation and the authors' abstract along with the identification of the type of model (MODEL TYPE) and a comment (COMMENT) about the suitability of the model for assessment of energy technology impact in agriculture. The model type is described by one of the following classes. 
(1) Mechanistic. Model based on physical, chemical, and/or physiological principles as appropriate. In some instances the physiological principle may be simplistic; for example, the use of ohms law to represent transport processes.

(2) Statistical. Model based on correlation, regression, or least-squares fit of observations to a given function.

(3) Stochastic. Model based on algorithm response to random variables derived from studies of event probabilities.

(4) Parametric. Model represented by a phenomenological function with parameters determined from analys is of empirical data without direct representation of the mechanisms involved.

Several papers provide program code listings, particularly those using IBM continuous system monitoring program (CSMP). However, this is the exception and it is anticipated that considerable effort would be involved in the application of the models by developing computer codes for the algorithms or through implementation of the original code obtained from the author. A further complication is also anticipated in that most models would require some adaptation for technology assessment. In the simplest case, an empirical relationship between some impact (technology origin) and an agricultural response would be required to be added to the models. This fact identifies the need for experienced input from personnel familiar with both modeling and dose-response or cause-effect relationships to extend the use of models to examine environmental effects of technology impacts. The dominant impacts of energy technology on aqriculture through 1990 will he frnm coal combustion effluents, particularly air pollutants. However, there are relatively few models of air pollutant-crop interactions identified in the bibliography even though there is a considerable empirical data base of pollutant effects on crops.

\section{Other Model Reviews}

Several review reports on aspects of modeling were identified in our survey, and although their goals were different than the present goals, these sources provide valuable information about models and modeling. 
File of Agricultural Research Models (FARM)

The U.S. Department of Agriculture has an active file of models that is currently maintained by Dr. Bruce Crane, Room 408, Nal Building, Beltsville, Maryland 20705 (phone 301/344-3937). We obtained a copy of the fourth release (November 1977) which contained an inventory of 111 models, many of which can be adapted for technology assessment purposes. Many of these models are not included in the present model survey, and the FARM document should be viewed as a resource for the modeling of technology impacts in agriculture.

Agricultural Systems Models and Modeling: An Overview

A review paper with the above title by G. M. Van Dyne and Z. Abramsky was published in 1975 in "Study of Agricultural Systems," (G. E. Dalton (ed.), pp. 23-106, Applied Science Publishers Ltd., London). Eighty-eight models were examined in the following categories: dairy 12, pest control 6, irrigation 1, fishery 3, wildlife 8, grazing 33, plant growth 25. Many linear programming-optimization models have been developed as aids in decision-making in various aspects of dairy operations. Many of the grazing models simulate plant growth and animal production and could be adapted to technology assessment by inclusion of representative dose-response algorithms. It is clear that in many instances available models cannot be applied directly to technology assessment.

\section{Mathematical Models in Plant Physiology}

J. H. M. Thornley published a volume (Academic Press, New York, 1976, $318 \mathrm{pp.)}$ that largely provides a compilation of his own modeling research conducted during the previous decade. Many of these models are outlined in Appendix A. Thornley's modeling research has been directed towards physiological research and a significant amount of modification would be required for application in technology assessment. 
Survey of Crop-Weather Models

D. B. Johnson reviewed 24 models in some detail for a MS Thesis in the Department of Meteorology, Pennsylvania State University (1976). He identified two main types of models: statistical and simulation. The former type has the same meaning as used in this document, while the simulation type includes parametric and mechanistic types as defined in this report. Models for wheat, maize, oats, soybeans, and sorghum were examined. The statistical models are restricted in their range of application to the soil, plant, and weather regime for which they were developed. These codes and the simulation types all require some adaptation for the technology assessment.

Survey of radionuclide Transport and Dosimetry Models HOFFMAN, F. 0., C. W. MILLER, D. L. SHAEFFER, and C. T. GARTEN. 1977. Computer codes for the assessment of radionuclides released to the environment. Nuc 1. Saf. 18:343-354.

\section{Abstract}

This article presents a compilation of computer codes that may be used for the assessment of accidental or routine releases of radioactivity to the environment from nuclear power facilities. The capabilities of 83 computer codes in the areas of environmental transport and radiation dosimetry are sumarized in tabular form. This preliminary analys is clearly indicates that the initial efforts in assessment methodology development have concentrated on atmospheric dispersion, external dosimetry, and internal dosimetry via inhalation. The incorporation of terrestrial and aquatic food-chain pathways has been a more recent development and reflects the need for satisfying the current requirements of environmental legislation and the needs of regulatory agencies. The characteristics of the conceptual models employed by these codes are reviewed. (Auth.).

\section{Qther Review Topjcs}

Several articles and monographs on particular aspects of modeling are outlined below. 
HESKETH, J. D., and J. W. JONES. 1976. Some comments on computer simulations for plant growth. Ecol. Mode1. 2:235-247.

\section{Abstract}

The status of plant growth modeling activities is reviewed for a general audience. Recently, excellent textbooks and review papers have been published which summarize past efforts in modeling plant physiological processes. Anyone interested in plant-growth modeling should be aware of this background material which describes the modeling tradition in the plant sciences. Presently, we need better critical evaluations of such models, including experimental techniques necessary for generating associated data. Such critiques should be aimed at users of large plant-growth models in other disciplines. Recent developments in the construction of cotton growth models are described. Modeling philosophy is discussed in relation to the above. (Auth.).

LEMEUR, R., and B. L. BLAD. 1974. A critical review of light models for estimating the shortwave radiation regime of plant canopies. Agric. Meteoro1. 14:255-286.

\section{Abstract}

A general review of geometrical and statistical light models is presented in this paper. In the geometrical approach, plant shapes are simulated by various geometrical forms described by characteristic dimensions. Geometrical models may be divided into two classes - those which consider individual shapes and those which consider an arrangement of shapes. In the statistical approach the location of plant elements is parameterized by various distributions. The type of leaf dispersion in space is the most important consideration in statistical models. Four different types of leaf dispersion are considered in this review: regular leaf dispersion, clumped leaf dispersion, random leaf dispersion, and variable leaf dispersion.

Hypotheses which underlie the various random and more generalized types of statistical light models are presented. Several models in the literature are discussed in terms of these assumptions.

Although, in many cases, required plant data and actual light measurements in the field are grossly inadequate for experimental verification of light models, it appears that the light regime in plant canopies can be adequately described by those models already available. However, for the most part, these models are very complex, and a synthes is of these fundamental models into workable expressions that can be used by agronomists, crop ecologists, and others concerned with breeding plants for more efficient

interception of light is needed. (Auth.). 
MONSI, M., Z. UCHIJIMA, and T. OIKAWA. 1973. Structure of foliage canopies and photosynthesis. Annu. Rev. Ecol. Syst. $4: 301-327$.

\section{Abstract}

It is apparent from this review of the vast amount of research work on the problems of canopy structure and photosynthesis that our understanding of canopy photosynthes is has been considerably deepened by the activities of IBP during the recent decade. The results obtained have been successfully used in breeding programs towards developing high yielding crops with erect leaf plant types. The results are also interesting and valuable for assessing the photosynthetic productivity of plants upon which virtually all life on earth depends.

A salient result from recent studies on canopy structure and photosynthesis has been the development of production models based on the theoretical and empirical laws of the major exchange process of energy and materials between plants and the ir environment. Special attention has been given to models dealing with light interception and photosynthetic relationships. Such light interception models have provided the mathematical procedure for the assessment of productivity not only of agricultural plant ecosystems but also of natural plant ecosystems, revealing that leaf inclination plays an important role in the photosynthetic productivity of plant canopies. These models have also been remarkably successful in clarifying plant behavior at the ecological level.

In relation to the interception of light by plant canopies, many attempts have been made to measure or formulate canopy structure. These studies made it possible to distinguish the canopies observed in natural and agricultural ecosystems into four types. Canopy structure data from field plantings of crops have been used to simulate the radiation environment and the photosynthesis of plant canopies. However, our information on the phytometric features of plant canopies, including the allocation of photosynthate, has not been as comprehensive as might be desired.

The development of computer technology has greatly facilitated the study of the interactions of plant communities with environmental factors. Although the computer simulation of plant growth seems to have success in integrating knowledge obtained in related disciplines, our efforts in exploring the biological and physical processes involved in plant photosynthes is have not yet necessarily been profound enough. The available information and working models of the relationships of photosynthesis and the environment are still meager and fragmentary. Particularly, the deficiency is greater for forests including fruit tree orchards than for crops with uniform plant 
stands of relatively low height. Many problems thus remain to be studied.

Attempts to make clear the phytometric characteristics and biological behavior of plant canopies under various environmental conditions and to refine the working models appear to be equally important for improving biophysical simulation of canopy photosynthesis and dry-matter production of plants. Such efforts should necessarily facilitate the increase in man's knowledge on the processes related to forecasting and controlling plant production. (Auth.).

WALKER, W. R. 1976. Assessment of irrigation return flow models. EPA-600/2-76-219. Robert S. Kerr Environmental Research Laboratory, USEPA, Ada, Oklahoma.

\section{Abstract}

Throughout the western United States irrigation return flows contribute to the problem of water quality degradation.

Evaluating the effectiveness of alternative management strategies involves models which simulate the processes encompassed by irrigated agriculture. The development and application of these models require multidisciplinary expertise. A workshop involving fifteen specialists in the varied aspects of irrigation return flow modeling was held to review the status of these models. Irrigation return flow and conjunctive use models recently developed by the Bureau of Reclamation served as focal points for the workshop. As the field verification and potential applications of these models were discussed, several general problems were identified where further investigation is needed. Particular emphas is was given to the description of the spatially varied aspects of soil, crop, and aquifer systems, and the proper alignment of model objectives with available data. The large number and diversity of existing models illustrate the individualistic nature of irrigation return flow modeling. In order to effect more widespread utilization of existing models, a systematic procedure should be developed to update and disseminate this modeling technology. (Auth.).

\section{Pudoc Publications}

The Centre for Agricultural Publishing and Documentation, P. 0 . Box 4, Wageningen, The Netherlands, has published the following simulation monographs:

(i) de Wit, C. T., and H. van Keulen. Simulation of transport processes in soils.

(ii) Beek, J., and M. J. Frissel. Simulation of nitrogen behavior in soils. 
(iii) de Wit, C. T., and J. Goudriaan. Simulation of ecological processes.

(iv) Fransz, H. G. The functional response to prey density in an acarine system.

(v) Frissel, M. J., and P. Reiniger. Simulation of accumulation and leaching in soils.

(vi) van Keulen, H. Simulation of water use and herbage growth in arid regions.

(vii) Makkink, C. F., and H. D. J. van Heemst. Simulation of the water balance of arable land and pastures.

Each monograph is the result of a few years' theoretical and experimental work and contains a full presentation of the simulation programs, preprogramming difficulties, and justification of assumptions with an emphasis on verification. 


\section{REFERENCES}

Baes, C. F., H. E. Goeller, J. S. 01son, and R. M. Rotty. 1977. Carbon dioxide and climate: The uncontrolled experiment. Am. Sci. $65: 310-320$.

Benedict, H. M., and W. H. Breen. 1955. The use of weeds as a means of evaluating vegetation damage caused by air pollution. pp. 177-190. IN: Third National Air Pollution Symposium, Pasadená, California.

Bennett; J. H., A. C. Hill, and D. M. Gates. 1973. A model for gaseous pollutant sorption by leaves. J. Air Pollut. Control Assoc. 23: $957-962$.

Bennett, J. H., and A. C. Hill. 1974. Acute inhibition of apparent photosynthesis by phytotoxic air pollutants. pp. 115-127. IN: Mark Dugger (ed.), Air Pollution Effects on Plant Growth. A.C.S. Symposium Series 3. American Chemical Society, Washington, D.C. $150 \mathrm{pp}$.

Brisley, H. R., C. R. Davis, and J. A. Booth. 1959. Sulfur dioxide fumigation of cotton with special reference to its effect on yield. Agron. J. 51:77-80.

Daines, R. H. 1968. Sulfur dioxide and plant response. Occup. Med. 10:516-524.

Davis, D. D., and R. G. Wilhour. 1976. Susceptibility of woody plants to sulfur dioxide and photochemical oxidants. Bull. EPA-600/3-76-102. U.S. Environmental Protection Agency, Corvallis, Oregon. $71 \mathrm{pp.}$

Dreisinger, B. R. 1965. Sulfur dioxide levels and the effects of the gas on vegetation near Sudbury, Ontario. Air Pollution Control Association, Pittsburgh, Pennsylvania.

Energy Information Administration. 1978. Annual Report to Congress on Projections of Energy Supply and Demand, Volume 11. DOE/EIA-0036/2. 
Feder, W. A. 1973. Cumulative effects of chronic exposure of plants to low levels of air pollutants. pp. 21-30. IN: J. A. Naegele (ed.), Air Pollution Damage to Vegetation. Advances in Chemistry Series 122. American Chemical Society, Washington, D.C. 137 pp.

Frey, H. T., O. E. Krause, and C. Dickason. 1968. Major uses of land and water in the United States with special reference to agriculture - Sumary for 1964. Agr. Econ. Rep. No. 149. Res. Serv., U.S.D.A., Washington, D.C. 74 pp.

Heck, W. W. 1973. Air pollution and the future of agricultural production. pp. 118-129. IN: J. A. Naegele (ed.), Air Pollution Damage to Vegetation. Advances in Chemistry Series 122. American Chemical Society, Washington, D.C. 137 pp.

Hill, A. C., and M. D. Thomas. 1933. Influence of leaf destruction by sulfur dioxide and by clipping on yield of alfalfa. Plant Physio1. 8:223-245.

Jacobson, J. S., and A. C. Hill (eds.). 1970. Recognition of air pollution injury to vegetation: A pictorial atlas. Air Pollution Control Association, Pittsburgh, Pennsylvania.

Katz, M., et al. 1939. Effect of sulfur dioxide on vegetation. National Research Council No. 815. Ottawa, Canada.

Le Blanc, F., and D. M. Rat. 1975. Effects of air pollutants on lichens and bryophytes. pp. 237-272. IN: J. B. Mudd and T. T. Kozlowski (eds.), Responses of Plants to Air Pollution. Academic Press, New York.

Linzon, S. N. 1958. The influence of smelter fumes on the growth of white pine in the Sudbury Region. Joint Publ. Ont. Dept. Lands and Forests. Ontario Department of Mines, Toronto, Canada.

Linzon, S. N. 1972. Effects of sulfur oxides on vegetation. For. Chron. pp. 182-186.

Ma, T. H., D. Isbandi, S. H. Khan, and Y. S. Tsing. 1973. Low level of $\mathrm{SO}_{2}$ enhanced chromatid aberrations in tradescentia pollen tubes and seasonal variation of the aberration rates. Mutat. Res. $21: 93-100$.

Mudd, J. B., and T. T. Kozlowski (eds.). 1975. Responses of Plants to Air Pollution. Academic Press, New York. 
Mudd, J. B. 1975. Sulfur dioxide. pp. 9-22. IN: J. B. Mudd and T. T. Kozlowski (eds), Responses of Plants to Air. Pollution. Academic Press, New York.

O'Gara, P. J. 1922. Sulfur dioxide and fume problems and their solutions. Cited in: Ind. and Eng. Chem. 14:744.

Reinert, R. A., A. S. Heagle, and W. W. Heck. 1975. Plant responses to pollutant combinations. pp. 159-177. IN: J. B. Mudd and T. T. Kozlowski (eds.), Responses of Plants to Air Pollution. Academic Press, New York.

Ryder, E. J. 1973. Selecting and breeding plants for increased resistance to air pollutants. pp. 75-84. IN: J. A. Naegele (ed.), Air Pollution Damage to Vegetation. Advances in Chemistry Series 122. American Chemical Society, Washington, D.C. 137 pp.

Schuck, E. A. 1973. Chemical basis of the air pollution problem. pp. 1-8. IN: J. A. Naegele (ed.), Air Pollution Damage to Vegetation. Advances in Chemistry Series 122. American Chemical Society, Washington, D.C. 137 pp.

Taylor, 0. C. 1973. Acute responses to plants to aerial pollutants. pp. 9-20. IN: J. A. Naegele (ed.), Air Pollution Damage to Vegetation. Advances in Chemistry Series 122. American Chemical Society, Washington, D.C. $137 \mathrm{pp}$.

Thomas, M. D. and R. H. Hendricks. 1956. Effect of air pollution on plants. Air Pollution Handbook, Section 9:1-44. McGraw-Hi11, New York.

U. S. Department of Agriculture. 1967. National Inventory of Soil and Water Conservation Needs. Statistical Bulletin No. 461. Washington, D.C.

U. S. Department of Energy. 1977. Annual Environmental Analysis Report. Washington, D.C.

U. S. Environmental Protection Agency. 1973. Compilation of Air Pollutant Emission Factors, AP-42, Second Edition. Office of Air and Waste Management, Office of Air Quality Planning and Standards, Research Triangle Park, North Carolina. 
U. S. Environmental Protection Agency. 1974a. Monitoring and air quality trends report - 1973. EPA/450/1-74-007. U.S. Environmental Protection Agency, Washington, D. C.

U. S. Environmental Protection Agency. 1974b. Supplement Number 3 for Compilation of Air Pollutant Emission Factors (AP-42), Second Edition. Office of Air and Waste Management, Office of Air Quality Planning and Standards, Research Triangle Park, North Carolina.

U. S. Environmental Protection Agency. 1975. Supplement Number 5 for Compilation of Air Pollutant Emission Factors (AP-42). Office of Air and Waste Management, Office of Air Quality Planning and Standards, Research Triangle Park, North Carolina.

Unsworth, M. H., P. D. Briscoe, and H. R. Pinckney. 1972. Stomatal responses to sulfur dioxide. Nature 239:458-459.

Wellburn, A. R., 0. Majernik, and F. A. Wellburn. 1972. Effects of $\mathrm{SO}_{2}$ and $\mathrm{NO}_{3}$ polluted air upon the ultrastructure of chloroplasts. Environ. Pollut. 3:37-49.

Wood, F. A. 1968. Discussion of paper on sulfur dioxide and $\mathrm{plant}$ response by Robert $\mathrm{H}$. Daines. J. Occupat. Med. 10(9):516-524 (Discussion - pp. 524-533).

Zahn, R. 1961. Effects of sulfur dioxide on vegetation - Results of experimental exposure to gas. Staub 23:343-352. 
APPENDIX A

AGRICULTURAL MODELS 


\section{APPENDIX A \\ Agricultural Models (continued)}

(1)

Aase, J.K., J.R. Mright, and P. R. Siddovay, 1973. Estiuating soil vater content on native rangeland. Agric. Meteorol. $12: 185-191$.

ABSTRACT: Model for estinating soil vater content on native rangeland vas tested at Sidney. Hontana. Based on the Penman $\infty$ abination nethod for estiating potential $E^{\top}$. the codel includes factors to acsount for crop developnent, liniting soil vater $\infty$ ntent, and increased evaporation af te $r$ rain. The udel gave reasonable estiates of actual soil water conditions within a $15 \%$ li lit suggested as being practical for rangeland anagesent por poses. (Auth.)

MODEL TIPE: mechanistic vith enpirical factors

CCHAEN: Hodel is a practical anagenent tool that reqoires tuning for a particular application. The nodel could be used as a coponent of a rangeland iepact assessent.

<2>

Mkanan, D.P... and M.P. Anderson. 1971. A quantitative investigation of a peristaltic Dodel for phloes translocation. Ann. Bot. 35. $761-772$.

ABSTRMCT: An analysis ls ade of a peristaltis udel of phloes translocation. It is postnlated that the periodic action of postulated that the periodic action of contractile or bending organelles drive a wich connect sieve pores in successive sieve plates. Plausible palues are assuned for the velocity of propagation of the contraction a ve, the frequency, the anplitude, and the $\nabla$ iscosity of the solution and its concentration, osing relations uhich describe peristaltic flow. predictions are ade for the values of paraneters such as the vecity of solution. the driping pressure. and rate of energy dissipation. These predicted alues are seen to be reasonable predicted values are seen to be reasonable
when conpared with the kncun properties of ot her biologlcal contractile systers. Thus the sodel is quantitatively acceptable. (Auth.)

MODEL TIPE: nechanistic

COAMEN T: Theoretical oodel of a plant process. Not useful in technology assessnent.

(3)

Alderfer, R.G., and D. A. Gates. 1971. Bnergy exchange in plant canopies. Ecology $52: 855-861$.

19STRACT: A theoretical aodel is presentel for the exchange of radiant and sensible heat be tween leaves in a plant canopy and the cn ironicnt. The distribution of short-wave (0.3-3.0 acron) radiation in a canopy is de scribed by a aodified for of the Kubelka-Munk equations for light transaission through scattering media. Opward and downvard radiation fluxes are computed for anp level of a canopy as a function of canopy density and optical properties of tho leavec. A series of sinultaneous equations is used to deteraine both theral radiation and lesf te aperature at ang point in the canopy. Bach te merature at ang point in the canopy. Bach for a leaf at that level in the canopy. This model uses inforation about the external physical environaeot together with optical properties of leares to predict the distribution of solar radiation, leaf teaperature, and theraal radiation throughout a plant canopy. Experiaents are reported wich test the reliability of the theoretical mode1. (Auth.).

MODEL TYPE: (Auth.)

COMMEN: This is a basic model of a canopy en ergy budget. Could be used to evalua te ef fects of change in canopy optical properties that ay be induced by acid rain or pollutant uptake.

〈4〉

less1. J.. and J.P. Power. 1965. Influence of -oisture, plant population, and nitrogen on dry land corn in the northern plains. Agron. J. $57: 611-612$.

ABSTRACT: The effects of total available soll coisture, plant population, and

fertilization upon dryland corn production were studied at 2 locations over a 6-year

perlod. Porage and grain yields vere highly

correlated with total avaflable nolsture

(soll nolsture at planting plus

precipitition). Optian population at each precipitation): Optinu population

ipplications of $\mathrm{g}$ were of little benefit. Applicat

GONEL TYPE: statist1cal - regression equatlons

cOHAET: Model is site specific to sidney, a nnd mandan. No. Probably of littio use in technolog 7 asse ssaent.

<5>

Mllen. L. ., 1974. Hodel of light penetration into a vide-roy zrop. Agron. J. 66:41-47.

ABSTRAT: This odel predicts di rect-bees radiation penetration into vide-rou crops. The crop is modeled as "hedge-rov" with an open iddle betveen the rous. Leaf area density is given helght and cross-row functional distributions, but is considered unifora along the length of the rov. Input paraneters uhich can be varied are: t1we of day, time of year, latitude, longitude. atmospherle transalssivity, slope of the soll surface, rov direction, rov spacing. arnp
height, udat of the hedge-row, leaf area height, lath of the hedge-row, leaf area angle. Ibe odel can predict the average angle. The codel can predict the average function of distance fron the rov, and the function of distance from the rov, and the sptea. Light penetration vas predicted for E-N, H-S, NE-SR, and NR-SE, con orientations for Auguet 17, 1967, using rov geouetry of E-R vide-row grain sorghun (SORGBOa BICOLOR L. Hoench) grown at Akron, Colorado. Lov predict lons of light interception in the morning and afternoon hy $p-a_{\text {ravs }}$ resulted in the lowast prohtigtions of dally total

intercepted light. Onder the input conditions, the odel predicted 37, 44, 42. conditions, the wodel predicted $37,44,42$ and $42 \%$ da1ly interception for E-R. NE-SR, and $N M-S E$ row orlentations,
respectivelY. The HE-SW row orientation mar be best since the model predicted that the wost light vould be absorbed at 1000 hours. when noisture stress would be lov. and the least at 1400 hours, when solsture stress vould be high. (Auth.)

MODEL TYPE: nechanistic

COMBENT: Hodel couls be used to evaluate fog or plume shadiuy effucts on rov crop radiction regine.

<6>

Alíen, L. H. 1975. Line-source carbon dioxide release, III. Predictions by a tro-diansional nuarical diffusion nodel. Bound.-Leyer beteorol. 8:39-79.

ABSTRACT: Model predictions of CO (2) concentcations downind fron a line source vere calibrated using experinental data. agreenent between tho model and exporimental data yas inproved by adjusting for wind direction eander and cup anemoseter dicection eander and cup anemoneter
orershoot. The model predictions showed that by using negative exponential uid speed by using a negative exponential vind speed profile within the crop canopy. predictions
were closer to observed co (2) concentration were closer to observed $C O(2)$ concentration wind speed profiles, which vere constant with 


\section{APPENDIX A Agricultural Models (continued)}

(6) COR.

holight in the lover canopy, vere used. This finding suggests that uch of the lover canopy airflow vas not direct ass flov in the dounvind direction. Rddy diffusioity profiles which shoved a vithin-canopy local profiles which shoved a vithin-canopg local ininus resulted in restriction in the predicted loss of CO(2) out of the canopy
sp stes. Two-diansiona 1 flots of predicted null vertical flux and co(2) concentration portrayed vividy the turbulent diffusion and wass fiov transport of $C O(2)$ fron the line source. (Auth.)

HODEL TYPE: nechanistic - 2D nuserical solution C CHMEN T: hodel requires experinental

calibration. Method could be used for assessing gas pollutant or gas fertilizer transport.

<>

Allen, L.H.. and K.A. Brown. 1965. Shortwave radiation in a corn crop. Agron. J $57(1): 575-580$

ABSTRACT: Near-infrared and total shortwave radiation were measured at various heights in corn using Japanese gro solariaeters, with and without appropriate light filters. Pron these measurenents, visible radiation was calculated. The resulting data indicated calculated. The resulting data indicat radiation ithin this crop vere not constant. radiation vithin this crop vere not constan higher percentage of the total shortwave higher percentage of the total shortwave radiation at the
the top. (Auth.)

HODEL TYOE: nechanistic vith enpirical paraneters COHERT: Paper describes a relatively simple nodel requiring four averaged radiation measureaents to iaplenent for a plant comounity. Effects of change in crop reflectivity can be evaluated.

(8) Solar ultraviolet radiat ion in terrestrial plant conuunities. J. Environ. Qual. 4: $285-294$.

AESTRACT: There has been a groving concern that No $(x)$ effluents from supersonic or other highflying craft. Or chlorofluorowethane refrigerants or aerosol can propelionts that. diffuse to the stratosphere, could cause a
reduction of a taospheric ozone. vhicb vould re sult in a concoultant increase of pe netration of solar ultraviolet radiation to the earth's gurfaco with possible biolngical consequences. Spectral aiseriouelons of di rect-bean and diffuse solar ultraviolet direct-bean and diffuse sol ar ultraviolet ir.radiance at the earth's surface. as a and solar elevation angle, have been accurately solar elevation angle, have been accurately our objectives vere to couple Incident spectra to a plant canopy radiation penetration aodel to give the redistribution of idde ultraviolet radiation, or ov-B (280-315 na), vithin plant canopies. Detailed ccofarisons were wade between two oz one content conditions $10.32 \mathrm{~cm}$, typical for $30 \mathrm{deg}$. N latitude and $0.24 \mathrm{ca}$. representing $25 \%$ ozone reductioni with a 60 representing a 25 ozone reduct loni with a 60 ar $B$ rad lation reglaes in plant conanities av-B radiation reglies in plant connunities characteristics, including erect leaf, nornal characteristics, including erect leaf, no leaf, and horlzontal leaf canoples, vere
computed. Clumped, randon. and regular leat distributions we re aodeled, as vell as leaf ar ea indices of $2.6,3.3$, and 4.0 .

Phyloelewent optical properties included ze ro transaissirity and $5 \pi$ reflectivity. Soll reflectivities of both $5 x$ and $20 x$ were used. Epldermal transulssion spectra vere used to predict UV-B radiation loads inslde leaves.
Predicted penetration of $0 \nabla-B$ radiation was wuch greater in erect-leaf than

horizontal-leaf zanopies. Opuard-directed OV-B Irradiance vas greater near the ground level than near the top of the canopy. In conclusion, the odel prediction described the range of op-B radiation regines to be the range of or-B radiation regiaes to be stratospheric ozone content and under a $25 \%$ ozone reduction. Data fron these ldealized plant conaunities can be interpolated for other plant canopy types and soll types to predict upuard or downuard ov-B radiation loads and dosages. (Auth.)

HODEI TYPE: nechanistic

coHAENT: This is an application of the SPA: nodel described by Leon. D. H.: Shavcr oft. B.H. (1971). The sun's vork in a corn fleld. B.H. (1971). The sun's vork in a corn fleld. extended to evaluate ov iapacts on other terrestrial ecosysteos.

〈9〉

Alen, L.B., S.E. Jensen, and E.R. Lemon. 1971. Plant response to carbon lioxide enrichunt under field conditions: A siaulation. Science 173:256-258.

ABTRACT: A comprehensive soll-plant-atmosphere computer siaulation odel (SPAF) predicted ap
to a us increase in carbon dioxide uptake by a crop enflched ith carbon dioxide at ground a crop enflched ith carbon dioxide at
level. Enrichuent rates of 225 and 450 kilogram of carbon dioxide per hectace per hour uere used. Siaulations covered a wide range of ind speed, crop height, and leaf area display. (Auth.)

NODEL TYPE:

connERT: Application of the SPAH aoded - This study assesses the possible inpact of elevated co(2) levels on plants.

$\langle 10\rangle$

Allen, L.R., D.R. Stewart, and R. R. Lewon. 1974. Photosynthests in plant canoples: Effect of light response curves and radiation source geonetry. photosynthetica $8(3): 184-207$

ABTBAC T: soil-plant-ateosphere conputer sianiation aodel (SPAG) was used to study the sensitirity of plant canopy photosynthesis to leaf irradiance response curves and to diffuse sky-sources of radiation. Trenty photosynthetically active radiation (PhAR) loaded classes on leaf elements in 15 layers of a plant canopy were conputed. The direct-bean radiation load on leaves was distribated as a broad band rather than as a sharp poak boouco lonf olononts vere oriented at $\nabla$ arious ongles with respect to the normil to the solar bean. The predicted can opy photosynthesis vas influenced strangly by the shape of the leaf irradiance response by the shape of the leaf irradiace response
curve at low levels of phar. since nuch of the leaf aterial was exposed to diffuse radiation on2y. The nodel predicted that a hlgh percentage of diffuse skp-source radiation would increase total canopy photosyothesis, even wen ve accounted for the overall decrease in global PhAR. Thls latter finding iaplies that cloud or overcast days ay not be a serious detrinent to total canopy photosynthesis in soue species, and that heayy haze ay actually enhance canopy photosynthesis in species wh enhance canopy photosynthesis in specie
low photosynthetic capacity. (Ruth.)

MODEL TPPE: vechanistic

COAnERT: Sensitivity analysis of sol1-plant-ataosphere oodel (SPAB). Hodel is well tested and could be used to evaluate effects of aicrozlimate and phystological changes produced by an energy technology on agricultural crops. 


\section{APPENDIX A \\ Agricultural Models (continued)}

$\langle 19\rangle$

len, N.H., and J.R. Laubert. 1971. Application of the principle of calculated risk to scheduling of supplemental ir rigation. II. J se on flue-cured tobacco. Agric. Meteorol. 8: 325-300.

AESTRACT: A siaulation aodel was constructed to test the application of an

irrigation-scheduling decision model which incorporated the basic concepts of calculated risk. Inputs for the rodel included: (1) the official probabllity precipitation forecasts for the periods "toda". "t onight" and "tomorron": (2) initial soil": "isture content: (3) daily precipitation: (4) daily mean temperatures; (5) daily potential evapotranspiration and daylength values: (6) functions relating existing soil doisture content and stage of growth to the corresponding daage done to the crop; and (7) cost of irrigation. The loss functions vere developed speclftcally for flue-cured tobacco. Two methods vere used for calculating the cost of the irrigation. The decision $c r i$ terion was applied by neans of the simulaticn model to data fron three gr owing seasons. The results were conpared to the results as arrived at by irrigating at a the results as arrived at by irrigating at a wa 5 ound that the nev critgrion lusing wis found that the neu crit ar ion (using either whod for calculating the cost of and achieved a better utilization of the available vater than did the $50 x$ criterion. While the state of the art does not allow extremely vell-based development of the input variables and paraneters, arailable data have shown the concepts of the aodel to pleld ad equate results. Buch futuro development of the a pproach rewains. hoverer. (Auth.)

MODEL TYPE: stochastic ut th eapirical functions

conngy i: The approach used in this work could be of value in assessaents of technology 17i pacts: Use of rainfall probability forecasts in odeling pollutant transport and ef fects. for exa ople.

〈12〉

Anderson, M.C. 1966, Stand structure and light penetraticn, IT. A theoretical a nalysis. J. Ap p1. ECò. 3: 41-54.

ABSTRACT: The constancy of $k$ in the relation of relative light intensity $I / I(0)$ to leaf area index $P$ - I I I (O) =e $-K P$ - is examined for a stand presuned to consist of foliage inclines at a constant anqle alpha. Then the relative at a constant angle alpha. Then the re lative light intensity aust be considered over a range of angles of penet ration beta, $k$ is not
constant unless alpha $=0$ deg., when $k=1$, if constant unless alphaso deg., When $k=1$, if transeission and reflection are neglected. increasing values of alpha. The values of $k$ for $d$ iffuse and di rect light are usually different. Sode implications of these tindings for prediction of photosynthetic production in plant stands is discussed. Tho limitations ioposed by the theoretical tr catacnt, compered with the structure of actual plant comanities, are briefly actual plant com aun
rovious. (Auth.)

GODI TYPE: aechanistic

comn $T$ : Analysis of Bouguer-Lambert laus, Shows that extinction coefficient is not a constant unless leaves are horizontal. This information can be ased in nore comprehensive plant grcuth aodels and be applied in technology assessment.

<13>

gaker. C.H., and R.D. Horrocks. 1976. CORNHOD, a d pamic siaula tor of corn production. Agric. Systems 1:57-77.

ASTRACT: After an extensive literature search copNion, a comprehensive mathenatical model that siaulates energy and gas exchange at the plant -ais interface, vas developed. predictions of profiles ( $C O$ (2) concentration. vater vapour, teaprature, light,

photosynthesis) in the canopy vere

biologically good enough for many

applications, but they revealed the

inadequacies in our understanding of the

environent within the plant canopy. Also

considered we re spring and fall tiliage and

harvest operations. After calculating

several spring freeze-thaw periods for the

test year, 1969, enough work days were

accunulated to conple te tillage operations, alloxing completion of planting by 12 yay. Two 63 hp tractors and associa ted equipaent
vere used to farm the 81 ha hypothetical farmstean nsen far toet furpococ. Bithout this large investment in equipwent. planting date vould have been delayed until late June or early July since the spring of 1969 was ver $y$ wet. The siaulated crop was grown under actual 1969 weather conditions. on 4

September the corn crop reached harvest aturity as gauged by $a$ GDD (Grouing Degree Day) 'clock'. The simulator prodicted a yield of $7368 \mathrm{~kg} / \mathrm{ha}$. This vas a gross

orer-prediction of the $4088 \mathrm{~kg} / \mathrm{ha}$ average reported for 1969 in central hissouri. This over-prediction was accounted for by the ideal conditions given the sidulator whon actual data were not available. This included 1 eaf angles, co(2) concentration, and stomatal resistance. Harvesting took 30 days to zouplete. using one four-rov sheller. two trucks, a fara elevator, and $127272 \mathrm{~kg}$ of storage capacity. It appeared that the farn dryer was the limiting piece of equipoent in the harvesting operation. This crop production si mula tor formo the basic franevork that eqn eventually analyze nore complex systens. Howerer, at this point, the sidulator is only in the initial stages of derelopment, and it should be realized that auch oore extensive developient is necessary before the ultimate siaulator is achieved. (Auth.)

MODEL TYPQ: wechanistic

comnENT: This is an extensiva codel dealing vith the full range of cora production operations from planting to grouth and harvast. Tho inpacts of energy technology on the various stages of corn production could be evaluated. through appropriate odification of the nodel.

$\langle 14\rangle$

Baker, D.N., and R.R. Heyer. 1966. Influence of stand geometry on light interception and net
photosynthesis in cotton. Crop Sci. 6:15-19.

ABSTRACT: The following goonetric variables interact to deteraine the nature of shade pattern in rou crops: solar altitude, the angle of the row with respect to the solar azimuth. plant size and planting pattern. Great change during the day was observed in the relative percent interception in all stands when the crop was young. In the early

norning and late afternoon NS rows
intercepted wore light than 8 rovs. percent l.11 tritiug Inn hogun o lovol ott at a loof area index of about 3 in the conventionally planted cotton. Little or no convergence in the percent interception VS. LAI curves for noon and noon plus or minus 5 hours was noted
in the NS-skip cotton up to an LAI of 4 on a per planted acre basis. This indicates that expenditure of net photosynthate in the further elaboration of nev leaf tissue vould be a good investment as long as the frult ultimately produced by the plant would have time to mature. Rov direction had no significant effect on the total daily net photosynthesis by cotton conventionally photosynthesis by cotton conventionally planted in $40-i n c h$ rove. On a per pla
acre basis the NS-skip planted cotton 


\section{APPENDIX A \\ Agricultural Models (continued)}

<14> ConT.

consistently out perforged the NS-solid stand and the $R$ - skip plan ted stand. In all of the st ands the daily time course of net photosynthesis paralleled rery closely the course of interception of solar energy. The light data from a flat surface receiver ay be adjusted for percent interception by any st and. regardless of geonetry, to give an arrorate prediction of net photosynthesis. (A uth.)

MCDEL TIPQ: statistical - regression equation c CHM T: Early study and eapirically tuned for hississippi conditions, Hot useful for assessuent since any other aechan photosynthesis prediction.

$\langle 15\rangle$

Balding, P.R., and G.L. Cunninghaw. 1976 . A of sinple and pinnate leaf nodels. Bot. Gaz. 137 (1): $: 55-74$.

ABST PACT: The heat dissipation of simple and pi nnate leaf models was compared in teras of boundary layer diffusion resistance to heat flux (Ra) using energy budget equations. The relationships of $R$ a to length of the leaf along the path of air flow (D). videh of the loaf perpendicular to the path of air flov (D). and uind velocity (V) vere deterained for the single leaf nodels by placing the in a low velocity, laninar flow wind tunel and asuring leaf odel tenperatures as a function of $D$. $W$, and $V$. The relationships of Ra to $D, P$, angle of interception of air flow (theta) by pinnate leat oodels, and distance betueen leaflets vere investigated. Equation coefficients were deternined by Equation coefficients were deterained by re qrossion analysis. The results indicat iaportant paraweters deternining the heat transfer characteristics of pinnate leaves. (a uth.)

HODEI TYPE: sechanistic

COMH ENT: A detalled treatment of a specific physical process. Energy technologies could change the leaf characteristics that influence heat exchange. e. g. enissivity.

〈16〉

Balduin, J.P. 1975. A quantitative analysis of the factors affecting plant nutrient uptake frot sowe solls. J. Soll se1. 26:195-206.

A BSTRACT: $A$ model of solute uptake by a grouing root systen is discussed in relation to the ability of a soll to support the nutritiona 1 requirements of plants. It is quantitative. and should apply to the absorption of nitrate. phosohate, and potassiu by grasses and arable crops. The principles, If not the detail, are relevant to all soils. The uas tested in an experiuent in which the ni trogen and potassium taken up by a rape

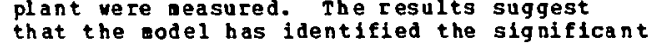
variables in the absorption process. The principal factors affecting the supply of nutrient to a given plant are the total quantity of diffusible nutrient, the rate at which the nutrient can oove, and the distance it has to travel to a root surface. The exact relevance of each factor for the exact relevance of each factor for the different outrients.13 readily determined. phosphate are often low. hass flow contributes little to theis supply, and an alequate exploitation of the soll reserves depends on a veli-developed root system. Nitrate, on the other hand, can usually cove easily to roots. either by aiffusion or nass flow. The whole rooting volume is depleted fairly quickly, and the a mount absorbed depends solely on the quantity present in the rooting rolune. These ideas have practical significance. In particular, they suggest that the soll properties which influence root growth aa deserve as uch attention as soil cheaical composition in the drawing up of fertilizer reconendations. (Auth.) MODEL IYPE: echanistic

conaris: Oseful for odeling.chealcal uptake fron solls. Reguires input properties that can be measured or estinated for a given situation.

<17>

Balduin. J.P.. P. B. Hye, and P.B. Tinker. 1973. Optake of solutes by altiple root systeas froa soil. III. A molel for calculating the solute aptake by a randonly dispersed root syste developing in a
plant Soil $38: 621-635$.

ABSTRACT: $A$ procedore is put forvard for calculating the plant uptake of solutes supplied by diffusion and ass flov to the $r a n d o n$ lispersed roots of a developing root systea. The model vas tested as follows: (a) for a constant root density and both (a) Eor a constant root density and both nuerical solution of the sase systea. (b) for an increasing root density and for supply by diffusion only - by electrical simulation using the analog described in part 1 . In both cases, results obtained by the two types of calculation were in close agreenent. A less accurate nethod wich includes both supply mechanis as and does not require computer is presented, and coapared uith an electrical sisulation ven there is no ass flow. Agreenent is vithin $20 \%$. The codel shouid be useful for predicting plant nutrient uptake fron soil and aay be of special interest to odeliers of the wole plant syster. (Auth.)

OODEL TIPE: aechanistic

COMHERT: very useful odel that can be adapted to estiate pollutant uptake fron soll. This nodel has been incorporated into the solute uptake sodel described by uxnoore et al. (1978) Ecol. Hodelling 5:137-171.

C18>

Balduin, J.P., P.B. Tinker, and P.H. Nye. 1972. optake of solutes by aultiple root systens from soil, II. The theoretical effects $O$ rooting density and pattern on uptake of nutrients from soil. Plant Soll 36:693-708.

ABS RACT: The analog described in Part $I$ is used to investigate quantitatively the effects of pattern and density on the uptake and uptake rate of nutrionts which wove to plant roots by diffusion. The uptake by two roots is considered first, to illustrate the conpetitive effect. The results for aultiple root systens are given for a variety of root systens are given for a variety of different ties and demonstrate the different times and demonstrate the uptake of different plant nutrients ia botb coupetitive and non-conpetitive situations. Pattern can decrease the uptake by root systens by at least 75 per cent, depending on the value of the diffusion coefficient, time, and root density. Graphs of tro indices of dispersion against uptake are given so that the effect of any pattern can be estianted. the effect of any pattern can be estial ted. uptake after anp tiae by a developing root systel to be predicted and conared vith a systea to be predicted and conpared vith a then the graphs show uhether soil or plant paraneters are liniting uptake. (kuth.) NODEL TYPE: electrical analog

ComENT: Model uses a 2D slab - This nodel has 


\section{APPENDIX A Agricultural Models (continued)}

〈19>

Barr. 5. 1971. A modeling study of sereral aspects of canopy flow. Hon. Neather Rey. $99: 485-493$.

ABSTRACT: Several a spects of canopy flow are investigated. The problea of steady flou in horizontaliy infinite canopy under neutral theral stratification is treated theoretically. The resulting analytical trode 1 is the n used as a boundary condition for a nonlinear nuwerical sodel designed to study transition regions near the leading and trailing edges of a canopy. This model shous a wa ve effect dounstrean frov a leading edge observed in the field and laboratory. A tendency for a splitting of the floy near a windward canopy edge is also brought out. (A urh.)

Thechentso

conH $T$ : Theoretical analysis that could be used to evaluate possible deposition patterns in foliage.

$\langle 20\rangle$

Barr, S.. and c. $W$. Kreitzberg. 1975. Horizontal variability and boundary-layer oodeling. Bound.-Layer Meterol. B: 163-172.

A BSTPACT: Microneteorologists have traditionallp set aside consideration of horizontal variability and have studied boundary-layer structure with horizontal honogeneity. The nugerical forcasting of boundary-layer st ructures, over nornally varying terrain and including noral disturbances such as fronts, requires selection of an 'appropriate horizontal scale. A staple analysis of steary-state bal ancs betveen hor izontal al vection and vertical diffusion provides estinates of the vertical scale (Or depth) of surface-induced features. The scale height is a function of the horizontal scale of the vaiations. Models neglect ing ieportant terrain scales of length belou approximately terrain scales of length belou approx ap proxinately 0.5 to $1 \mathrm{k}$. while those that ap proxinatelf 0.5 to $1 \mathrm{~km}$ vile those that neglect iuportant terrain scales belov ap proxinately $100 \mathrm{~km}$ can predict down to
ap proxiately 0.2 to $0.6 \mathrm{ka}$. Below these levels, any predicted features vili be do ainated by the rertical diffusion so that they are solutions of a one-dieensional boundary-value problew. The boundary-induced aj vection effects doulnate free at osphere adrection effects in the lovest few hundrej neters is well. This means that if vesoscale at vections are resolved and terrain

influences are strong. the predict lons in the influences are strong. the predict lons in the ayer a pFroxiately 0.2 to $0.8 \mathrm{ka}$ can provide onditions above the surface, because the conditions above the surface, bcase the surface

ODEL TYPE: nechanistic

COMM T: Theoretical analysis that can a id in valuation of terrain effects on turbulent transport in the atmosphere.

$\langle 21\rangle$

Barron, N.A...J. OPougherty, and D.S. Boyce. 1973. simulation codel study of plant spacing, establishnent and thinning on sugar be et $\mathrm{Y}$ ields. J. Agric. Eng. Res. 18:369-384.

AESTRACT: A sinulation codel of sugar beet producticn covering the stages of seed placeaent, establishuent, thinning. growth and topping was used to evaluate methods of hand thinning, blind thinning, achine selective thinning, and planting to stand. The results vere used to provide inforation on how initial plant spacing, its standard on how initial plant spacing, its standard affected the yield of correctly topped beet af fected the yield of correctly topped beet spacing and standard deviation requirements for maxioun net yield returns varied with nethod and establishent levels. A standard deviation of 1.0-1.5 in $(25-38 \mathrm{na})$ vas acceptable. In general, the results euphasized the inportance of hlgh establishaent levels which tended to produce even stands. Rith good establishment. differences in good establishment, aethods were suall: therefore, the selection of a cethod is dependent upon 1ts costs and only to some extent on associated field advantage. (Auth.)

MODEL TYPE: stochast ic

COHAET: Specific to sugar beets - could be used to exanine plant density effects, but this is probably onip iniliectlp related to energy technology iepacts.

$<22\rangle$

Barthakur. N. 1975. Ose of aicrovare radiation to study plant-enri ronaent interactions. J. hicrowave Pover 1019):441-449.

ABSTRACT: A closed-circuit wind tunnel and an external a ictougre energp source forned the basis of an experimental technique to investigate relationships between clinatic par aleters and leaf tenperatures. Ihe results of these prelininary experinents are conpared vith theoretical results obtained by solving the energy balasce equation for a single leaf. Time-tenperature relationship of an attached bean leaf, exposed to of an attached bean leaf, exposed to mathenatical odel vhich is essentially derived fro a knowledge of the cooling coefficient and the absorption factor. At high absorbed radiation and in darkness. stonatal opeoing of a real bean leaf ay reduce lts temperatore betueen 2 to $5 \mathrm{deg}$. $c$. (Auth,)

conns: oseful in the assessient of aicrovare effects on leaf tenperature.

$\langle 23\rangle$

Bartos, D. L., and D.R. Jameson. 1974. A dynamic root odel. Aa. Midl. Nat. 91:099-504.

ABTRACT: Root fluctuations of a shortgrass ecosysten were deterained vith 256 cores taken over efght saapiling dates during the sumber of 1969. Soll cores vere taken to a depth of $80 \mathrm{~cm}$ to deteraine the entire proflle distribution. Sone 60 of the root veight was in the $0-$ to $10-\mathrm{cm}$ segnent, and this increaent had significant variations betveen dates; hove ver, the lover levels remained quite constant. The usual concept of carbohydrate storage in roots, and its of carbohydrate storage in roots, and its subseguent ut llizat lon, vere not adequate to of root weights did not coincide with perlods of leaf initiation and seed production. A - at hesatical lodel which Includes concepts of root deconposition and grouth vag fornulated to represent the fluctuations: the oodel consists of two logistic equations added together. The equation vas fitted to the original data in direct search curve-fitting progras. The resultant curve vas separated into an increasing curve representing growth and decreasing curre representing growth and a decreasiag curve losses. According to the nodel. grovth ust necessarfiy begin before, and deconposition ust continue after, the time of ainiau root veight. Thus, these curves, under sereral assunptions, all indicate that losses and replacenents in roots are greater than those which are represented in the usual root turnover equations. (Autb.)

HODEI TTPE: statistical

conHRY : hodel could fore the basis for exanining an energy technology inpact on grassland ecosystens. 


\section{APPENDIX A \\ Agricultural Models (continued)}

<24>

Belot, Y. A. Baille, and J.I. Deleas. 1976. Modele nuserigue de dispersion des polluants at as pherigues en presence de couverts at aospherigues en presence de couver

astract: A numerical odel of at mospheric pollutant dispersion was developed in order to analyse the effects of a plant canopy on af concentrations. The increase in surface roughness is shown to significantly influence the concentration distributions. Horeover the integrated velocities of deposition and the pluse depletion are evaluated for particles and so (2) passing over voodes strips. The oodel is particularly useful to larn hou and there dry deposition occurs in high canopies such as forests. (Auth.) MODEL TYPP: lechanistic

COHAN r: Oseful for assessuent of a thospheric de position of pollutats in plant commities.

$\langle 25\rangle$

B lackl ov, H. 1973. Silulation nodel to predict geraination and esergence of cora (ZEA HATS L.) in an environent of changing teaperature. Crop Sct. 13:604-608

ABSTRACT: A sieulation nodel was developel based on system that included the processes of mars L.) radicle and shoot and the events of germination and energence. The response of germination and energence. The response of in previcus papers. Geraination vas predicted In previcus papers. Geraination vas predict at a critical level of rehydration of the sed. Subsequent to geralination, the rad and shoot vere elongated until the shoot nodel vas to give a continuous record of the change in state of the systee until energence ocurred. The systen was updated each hour by si wulaticn based on a knoviedge of soil teaperature. The oodel gave good predictions under fluctuating temperatures in controlled en if rongents and in the field. The verified endel supported the hpoothesis that the model supported the hppothesis that the respond to prevailing temperatures with adaptation to preceding conditions. And that adaptation to preceding conditions, and that the systen responds uithin ainutes to changes
in temperature. The aodel was not de veloped to predict responses to tenperature stress (less than $10 \mathrm{C}$ or are than $32 \mathrm{C}$ ) or to te npe rature if other soil factors were liniting. (Auth.)

MODEL TYPE: aechanistic

COMnEN T: Hodel could be used to assess soil te ape rature inpacts of technology on qeraination and oncrgence of agricuitural crops. oseful in vaste heat utilization cor ex ample.

$\langle 26\rangle$

Boast, C.R. 1973. Hodeling the movenent of chemicals in solls by water. Soll sei. $115(3): 224-230$

ABSTRKCT: Hodels describing the woveaent of chemicals through soil provide a good example of applying nodeling techniques to the soil-vater systea. Sone of the classical ascroscopic continua theories which have been developed are presented here in table forw. The enphasis of ost studies of the forw. The etphasis of ost studies of aovent of chenlcals has been on the influence of steady. water flow. Recently approxiaations have been made to give better
solutions for nonsteady flows. In principle. flov models can be used to describe the processes of soll foration: hovever. the complexity of such athenatical nodels ay be prohibitive. (Auth.)

MODEL TYPE: wechanistic

C CHMEN: Gi ves comparison of atheatical functions describing chemical movesent in soils. Many of the functions are taken froa open literature. Oseful review paper.

<27>

Booth, R.S., O.R. Burke, and S. V. Kaye, 1971. Dynanics of the forage-cow-ailk pathuay for transfer of radioactive lodine. strontiun, and cesiug to man. Proc. of Ae. Nucl. Soc. topical neeting on nuclear methods in cnvironeental research, pp. 127-143.

ABSTRACT: A systers analysis nodel was developed to predist the time-depenjent concentration of radiostrontiug, radiocesius, and radiolodine in the silk, eat, and soft tissue of covs that forage a pasture contalinated by fallout. The variables in this odel are adjustable to a vide variation this oodel are adjustable to a vide variation and counter cond lons, ecolog and counterasures. Siaulated conservative paraeters derived conpletely from publ ished measurenents. There was continued contanination of the ilk and neat several veeks after short-ter deposition on the grass (radioactive cloud above the pasture for $1 \mathrm{hr}$ ). Hovever, the concentration in silk was in transient equilibriun vith the grass (a 14-day environnental half-time for loss of radioactivity fron the grass vas specified) within a week after the deposition, and the ajority of an's aptake of radioactivity fro consulion of aptak neat vas acconplished within the first fev veeks after deposition. The transfer of radioactivity to an vas allost exclusively via the direct grass to cow gut to cow blood (body fluid) to weat and to illk pathuay The predicted equilibriun concentrations indicate the potential uptake by an fron a continuous source of radioactivity above the pasture. The Influence of environuental conditions and counterneasures vas studied. If, for exanple, the cows vere noved fros the contaninated pasture 1 day after an inpulse source to the grass, the cunulative inet and source to the grass, the cumulative neat and obtained uhen no counteraeasures are applied. (kuth.)

MODEL IYPE: systems analysis with empirical transfer coefeic

zonsent: Oseful codel for nuclear assessnents.

$\langle 2 \mathrm{~A}\rangle$

Brennan, R.D.. C.T. de Mit, W. A. Milliass, and B.V. Quattrin. 1970. The utility of digital siaulation language for ecological odeling. Decologia (Berl.) 4: 113-132.

ABTRACT: Dynalc pheuuñena lias been groably faoliltated by the recent developient of continuous system sinulator prograns. This paper lilustrates the application of one of these prograss. $5 / 360$ Continuous systea Modeling Prograw (S/360 CSHP), to four spstens of graduated conplexity. The first is a two species systea, vith one feeding on the other, using differential equitions wth congtant coefficients. The second and third systeas involve two coepeting plant species in which the coefficients of the differential equations are varying vith tide. The final example considers the vanagenent of a postulated buffalo herd in which the dquaics of the herd population and composition by sex and the is copbined uith parious strategies and age is conbined with rarious strategies production. (Auth.)

production. (kuth.)

COMBnY: Paper discusses csup conputer language and applications to species competition. plant size distribution and buffalo her wanagenent: 


\section{APPENDIX A \\ Agricultural Models (continued)}

$\langle 29\rangle$

rook, R.R. 1975. A rationale for deteraining spacing of levels in numerical odels of the at mospheric boundary layer. Bound.-Layer me terol. $8: 447-451$

ABSTRACT: It is suggested that since diffusion is the principal vertical transfer aechanis. in the boundary layer, the wixing-length concept can be used to deteraine the spacing be tween levels in nuperical nodels. An analysis of the vangara Experinent

boundary-layer data suggests that for that location, a vertical spacing of about 18 of the saliest horizontal scale is appropriate in the spiral layer and that $t$ his is constant vith height, (Auth.)

MODEL TYPE: aechanistic appications. oseful in ataospher ic transport of pollutants.

$\langle 30\rangle$

Broun, R.R.. and N.J. Rosenberg. 1973. A resistance nnal to predirt

evapotranspiration and its application to a sugar beet field. Agron. J. 65:341-347.

A STTPACT: method is needed to extrapolate the detailed nicrometeorological and lysinetric deterainations of evapotransplration and its dependence on the nicrocliate and crop factors to fields where such detailed measureaents are not wade. The dependence of latent heat flux (LE) fron a crop on crop resistance ( $r(c))$, air resistance ( $(a))$, air taperature (2(a)), water vapor pressure (a) (a) and net radiation ninus soil heat (elu (an-s) uas eqaluated by seans of an electrical resistance analogue of the transfer process (referred here as the nodel) transfer process (referred here as the node and by aeans of an energy balance equation. The difficalties inherent in the application of the wodel to both the single leaf and the crop are discussed. The a jor difficulty in applying the resistance model to a field crop ma $y$ be that the sinks and sources of latent and sensible heat flux may not be identical nodel and determined by the energy balance ge neraliy agreed vithin 5x. Daily totals of LE. evaluated by the two methods, agreed well on all occasions. Despite the objections to use of this odel for a crop. it minicked the behavior of the irrigated sugar beet crop used here. As ore detailed data on ex perimental fields becones avallable, the ex perimental fields becones avallable, the model may prove useful in extrapolation to extensive vegetated areas. It aay also be total hydrologic spstens in which evapotranspiration is an important component. (A uth.)

MODEL TYPE: nechanistic

C CMHENT: Model of evapotranspiration developed from icroneteorological approach. This method requires meteorological inputs and is uncoupled frow a mechanlstic soil-plant model. Probably has linited use in technology assessment.

$\langle 31\rangle$

Bunnell. P.I.. D.P.N. Tait, P.N. Planagan, and $\pi$. van Cleve. 1977. Microbial respiration and substrate veight loss. I. A general model of the influences of abiotic variables. Soil Biol. Biochea. 9:33-40.

ARSTRACT: A general oodel of the influences of abiotic variables on aicrobial respiration and substrate veight loss is presented. The model, a couplex hypothes is relating microbial respiraticn to temperature. mo isture, $O(2)$ and substrate, "explai
$71-96 \%$ of the variation in aerobic respiration rates measured from a variety of natural sutstrates. The aodel can project seasonal patterns of veight loss and thus peraits evaluation of laboratory respiroaetry against field weasures using 11 tter bags. osing data fron several countries sinulated losses due to icrobial respiration are 70-90x of the seasured litter bag loss. (Auth.)

HODEL TYPE: Iechanistic

COHART: Hodel reguires four eapirical

paraneters and could be adapted to a range of slluations. Evaluaton of physlcal

environgent inpacts could be a ade.

$\langle 32>$

Bunnell, P.L., D.E.N. Tait. and P.H. Planagan. 1977. Microbial respiration and substrate weight loss. II. A nodel of the lofluences of chenical conposition. Soll Biol. Blocher. $9: 41-47$

ABSTRAC T: Three models of the influences of cheaical coaposition on alcrobial respiration and substrate velght loss a re presented. The three approaches represent different aean of incorparating influonsos of toapocature and oisture upon chenical-specific respiration rates. Although influences of tespiration rates. Nlthough influences of temperature and oolsture dowinate icrobial respiration patterns, chenical-specific respiration do exist ith ethanol soluble substrate rapialy as non-ethanol soluble components (depending upon teeperature). Simulation podels are utilized to project and relate the laborator seasures of icroblal respiration to field measures of substrate velght loss. otilizing chesical-specific respiration rates. Siaulated rates of veight loss frou ethanol soluble and non-ethanal snluhle substrate conponents are $48 x$ and $12 x$ per $7 r$. heasured rates are $49 x$ and $11 x$. After the initial period of relatively high leaching. changes in substrate veight and cheacal composition result largeig fron changing icrobial respiration rates which are chenical-speciflc and indepentently influenced by teaperature and noisture. (Auth.)

HODEL TIPE: wechanist ic

COMNENT: Not readily applied to technology assesseent vi thout first experimental deteraination of the inpact effect on respiration and deconposition.

(33)

Bunting, E.S, 1972. Ripening in matze Interrelationships between tioe, water content and veight of dry aterial in ripening grain of a flint $x$ dent hybrid (Inra 200). J. Agric. Sci. Canb. 79:225-233.

ABSTRACT: Results are reported of ripening studies with aize (var. Inra 200) at oxford, 1967-69. Sovings vere made in late April or early in Hay, and crops grown at a standard density of 7.2 plants $/ \pi^{*} * 2$. Mreas vere provided ith cloche protection, for a a- to 5-ueek period from tiae of souing, to produce materiai for studies of the effects of

flouoring tioe on ripening patterno. Pros

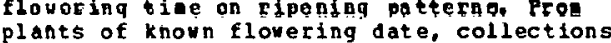
of 30-40 ears vere taken at intervals froa 30 until 100 . days after sliking. Information is presented on water content, grain dry veight and nuber of grains/ear at the various tiaes of harvest. Asyoptotic. polynonial and inverse-polynoaial regression wodels have been fitted to the data to elucidate the interrelationships between tine (aeasured fro date of silking). grain water content and grain dig veight. In plants content and graind ry veight. In plants increase in dry velght until water content increase in dry velght until water conte
was reduced to $35 \%$, whereas in plants was reduced to $35 \%$, uhereas in plants
flovering early in August axiau dry velght was attained at a water content of around 


\section{APPENDIX A \\ Agricultural Models (continued)}

<33> CONT

40x. Maxima dry veight of grain vas

approxiutely 10 higher in the earlier flowering plants: the corollary is that in the arginal areas of alze grain production in England aturity in such varleties as Inra 200 is often imposed by the environaent with a consequent loss in potential gield. In the early flowering plants, the tioe taken fron silking to reach lig harpestable stage of 408 grain vater content vas 69 d in 1967,79 d in 1968 and 64 d in 1969 . Rate of rater loss 1968 and 64 d 101969 . Rate of vater loss fron the grain during ripening vas closely the later flowering plants, differing by an average of 11 d in tise of silking, 8 days longer vas required for grain to be reduced to $40 \%$ vater content. giving an average difference of 19 days in pernissible dates of harvest. The results suggest that, in varieties of sioflar ripening pattern to Inra 200 , a advance of bout 7 days in flowering tiae is required to establish the alize grain rTop heyond its present confines in southeast England. ( $\mathrm{xuth}$.)

MODEL TYPE; statistical

C CAHEN T: Regression equations are dereloped for English conditions. alght be useful to compare with any inpact that changes cereal ripening patterns.

$\langle 34\rangle$

Bureau of Reclanation 1977. Prediction of wineral quality of irrigation return flow. mineral quality of irrigatfon ret
EPA-600/2-77-179a. OSEPA. Ada, OR.

ABS?RACT: This volune of the report outlines the purpose and scope of the return flov research and specifically explains the capablities of the conjunctive use oodel for predicting the ai neral quality of irrigation return flov. The purpose of the research vas to develop a conjunetive use nodel which would (1) predict the salinity contribution from new irrigation projects and (2) predict the change in return esult fro:

operational changes on existing projects.

The model dereloped and described herein describes the chenical quality in teras of eight ionic constituents and total dissolved solids a nodal concept has been used to facilitate subdividing the profect area along physical or hydrologic boundaries as desired. The study ay be lilited to 1 or as any as 20 nodes. A description of the $\nabla$ ernal pleld studg which describes the physical setting for the nodel testing is included. A narrative describing the probleas encountered - Ith the orlginal dato is inoludod. A date collection progran as init iated to fill the a.ps. The wodel satisfactorily sialated the nev 2 - 7 ear data base. Tables and figures new 2 - vear data base. Tables and figures frow the verification are included. Results of model operations for the cedar Bluff and Grand valley a reas are also described. It is concladed that the oodel can satigfactorily be used to siaulate irrigation return flows if sufficient data are available, especially groundwater hydrology and chesistry. This re nnrt yas silhait.ted in fulfillnent of Project BPA-IAG-D4-0371 by the 0.S. Burea of Peclanation, Englneerlng and Research Center. under the sponorship of the Environuental under the sponorship of the

MODEL TYPR: aechanistic

c carant: This five voluae series is an extensive nodel developrent and testing study concerned vith water quality. It has considerable utilty in ovaluation of some energy technology inpacts.

$\langle 35\rangle$

Byrne. G.P. 1975. A siople method of calendar converion in oouputer applioationc.
Discussion. Agric. Heteorol. 15:419.

ABSTRACT: A lethod of data conversion for use in the conputer handing of clinatologlcal and sinilar data is described. The procedure incorporates a test for occurrence of leap years and also a test for autosatic conversion in either direction. (Auth.) HODEL TYPE: algebraic

cOHABT: Oseful algorithe in odel applications requiring date conversions.

$\langle 36\rangle$

Caassen. H.. and S.A. Barber. 1976. Siaulation oodel for nutrient uptake fros soil by a grouing plant root systen. Agron. J. 68: $961-964$.

ABSTRACT: nat hea atical nodels of nutrient uptake by plants a re useful for investigating the effect of various soll and plant factors on nutrlent flux to plant roots. The objective of this research as to develop a nodel based on theoretical considerations of the processes of putrlent uptake by plant roots growlig in soll and then to test the model experfentally. The soll and plant factors used in the odel vere to be measured independent of final nutrient uptake. The adel for flux by ass flow and diffusion to the root was patterned after that of Nye and Marriott. The absorption kinetics of the root were assuned to follow Hichaelis-Menten kinetics. The Nye-Marriott model gives the nutrient concentration the root with tiae. pros this accunulated uptake per ca**2 of root surface ith tiae vas calculated. Rate root surface ith tiae vas calculated. Rate the grovth of the young plant. optake per ca**2 of root with tise was coubined wathenatically uith rate of root grovth to get total uptake ith tine by the plant. The present progran issues root hairs do not affect uptake and that roots do not conpete for nutrients. A conputer progran was vitten for solution of the nathenatical adel. The factors required in the sodel from the soil are: effective average diffusion coefficient. Initial nutrient concentration in solution, and buffering capacity. For the plant they are: the capacity. For the plant they are: the solution and net influx into the root. vater influx. root radius, Initial root length, and rate of root grouth. The nodel was tested for ueasuring $R$ uptake by corn (2EA MATS L.) froa elght different soli-k cosbinations. The corn was grown in a grouth chaber and $R$ uptake vas eeasured for the period of plant grouth from a th to and 13 dags. The calculated uptake, $y_{\text {. }}$ was correlated vitb observed uptake, $x$, by the equation $y=0.155+1.566 x \quad(a * 2=0.87)$ vhere $y$ and $x$ are $y=0.155+1.566 x \quad(R * * 2=0.87)$ uhere $y$ and $x$ are
acronoles of $\mathrm{K} / \mathrm{plant}$. Calculated optake was overestiated by about 50x, possibly because overestiated by about 50x, possibly because coepetition occurred between roots for soll and $\mathrm{k}$ ws not absorbed by the root as fast useful for investigating the principles of nutrient absorption by plant roots fros soll which can be used for developing aore efficient systens of fertilizer application.' (Auth.)

MODEL TYPE: vechanistic

COnABRT: Research model that could be adapted to torhnology assessepit.

$\langle 37\rangle$

Campbel1, H.D., G.S. Caopbe11, R. Kankel, and R.I. Papendick. 1976. A model describing soil-plant-water relations for potatoes. Aner. Pot ato J. 53:431-441.

ABSTRACT: $A$ simple stead 7 state nodel is derived which describes the diurnal water potential fluctuations in leaves and tubers of pot atops. The angitude of these 


\section{APPENDIX A \\ Agricultural Models (continued)}

<37> con T.

fluctuations is shoun to depend on transpiration rate, hydraulic properties of the soil. rooting depth and density. resistance to flow of vater vithin the plant. and the leaf water potential at which stonatal closure occurs. Hodel predictions ag ree quite vell vith aeasurenents aade in the field and in the growth chasber. The nodel is used to predict the lower liait of readily available nolsture for potatoes and shovs the important environmental and plant factors. (Ruth.)

MODE $\mathrm{L}$ TYPE: nechanistic

COHAN T: JsEfUl hodel for assessaent of energy technology effects on water ralations of potatoes.

$\langle 38\rangle$

Carbon. B.A., and R.A. Galbraith. 1975. si ulation of the vater balance for plants growing cn coarse-tertured soils. Aust. J. So il Res. 13:21-31.

ABSTRACT: A coaputer siaulation sodel of the vater balance for plants qroving on coarse soils vas developed and tested against field measurewents. The inputs for this nodel are measurable physical paraeters. Pron the close agreenent retween simulated a nd ob served results it is suggested that observed results, it is suggested that drainage ay be satisfactorily predicted. (Auth.)

MODEL TYPE: nechanistic

C CHAENT: Enpirical nodel tuned to vestern Australian conditions. has the advantage of reguiring relatively few input data. Pr obably not readily applicable to technolog as sessuent.

<39>

Charles-Edvards, D. R.. and J.H. H. Thornley. 1973 . plant - Asiople oodel. Ann. Bot. 37:919-928. ABSTRACT: A simpie aodel for light intarception by an isolated plant is proposed. The model as sumes that the leaves are uniforaly distributed over a region of space bounded by an ellipsoid and a plane, and that light traversing this region is attenuated according to Beer's lav. It is shoun how the model can be extended to exanine a closed rox of plants. Or a closed array of plants. of plants, or a closed array of plants. for single plants ith different shapes, and an isolated row of plants, under unlfora and st andard overcast skies. (Aath.)

TODEL TYPB: nechanistic

c craEn T: Prcbabily not useful in assessuent. the wethod could be incorporated into more comprehensive wodels of plant function.

〈40

Chen, C.S.. and J.T. Clayton, 1971. The effect of tepperature on sorption 18otheras of biological aterials. Trans. of the ASAB tu $=927-929$,

A BSTRACT: This paper presents an analysis of sorption isotheras pertaining to hygroscopic an teriala. Tro two-paraneter and one three-paraneter enpirical sorption equations vere investigated for a nuber of grains. At a given teaperature, chen's equation exhibited the best fit of the three equations. A neu four-paraneter equation relating equilibriug aisture content, air relative huidity. and equilibriua relative huaidity, and equilibriua simplified chen equation. Applications to simplified Chen equation. Applications to published data on a nuaber of aterials indicate that the goodness of fit of the and Nelson's wodified Henderson four-paraneter equation. (kuth.) HODEL TYPE: aechan ist 10 zOABR日T: Jseful 1 ode 1 in the application of vaste heat in drying biological materials.

<41>

Chen, L.H., B.R. Huang, and W.E. Splinter. 1969. Developing a physical-chemical nodel for a plant grouth systea. Trans. of the ASAB 12:698-702.

ABSTRACT: Grouth was considered as a function of tro a jor energy conversion processes photosyntbesis and respiration. A functional relationship between photosynthesis,

respiration, and grovth uas developed. onder present studies, the inforation avallable for conplete evaluation of nodel constants is not sufficient. A thorough study on the following subjects vill ake this nodel core sat isfactory: (1) Tenperature effect on rate of photosynthesis (2) Interactions betveen light intensity and teaperature effects on rate of respiration (3) Tenperature effect on rate of translocation. (iuth.)

MODEL TYPE: wechanist IC

COHAET: Hodel is based on a lunped plew of plant grovth. Could be useful for

assessment; howerer, other plant grovth models ay be more suitable.

<42>

Childs, S.H.. and R.J. Hanks. 1975. Hodel of soil salinity effects on crop grovth. Sol Sci. Soc. Al. Proc. 39:617-622.

ABSTRAC T: The aodel considers properties of the soil, water, plant, and atmospheric systen to predict relative crop yield, crop pield predictions assume a direct relation betveen dry atter production and transpiration. The only salinity effects considered are osuotic only salinity effects considered are oseot
potential. The influence of initial soil potential. The influence of initial soil salinity on cropgrowth depended upon crop type and irrigation anagenent. years show that sone water nanagent systens would produce high gields for several years before salt buildup ould dectease glelds. Predictions shov that the influence of irrigation systen unifornity on salinity buildup and gield reduction is rery iaportant. (Auth.)

MODEL TIPE: echanistic

coning : hodel could eraluate the use of blowdoun vater for crop irrigation.

〈43>

Chung, C.R.. J. Duffy, and B.A. H1rsch. 1974. SYsteas na nua 1 for PIEID, a prograa for the siaulation of nitrogen fiow in a corn belt field. CBNS Report No. 7402, Nashington Oniv... St. Louis, no.

MODRI, TYPE: parametric

consent: very useful oodel that could be adapted to evaluate technology inpacts in silliar situations to the corn belt field used in the codel deqelopant and application.

〈4a〉

lonco. R. H. 9965. A wathenatical model for air flov in vegetative canopy. J. Appl. Meteorol. 4:517-522.

ABSTRACT: The objectives of this study are to investigate the turbulent transfer of coentur ithin a vegetati ve canopy and also to develop a eathenatical odel vhich expresses the aerodpanic roughness effects of the surface boundary in terms of the height, density, and drag characteristics of helght, density, and drag characterist a regatical oodels have been formulated. matheaatical models have been formal theoretical and eapirical aspects of the two 


\section{APPENDIX A \\ Agricultural Models (continued)}

(44) conT.

previous lodels and other available canopy ob servations, Conputed aixing length solutions showed that the elxing length, 1 . was nearly constant throughout wost of the canopy's vertical extent and also that 1 increased 11 nearly with helght above the ca nopy. The computed canopy uind profile solutions verified that the eixing length is nearly constant uth height uithin a ture corn plant canop and that lie sinulated canopy uind profiles agreed quite vell vith canopy wind profiles agreed gaite vell vith the independent check on the codel was An independent check on the codel vas performed using wiad tunel data for an artificial canop 1th the observed data. Exaeple profiles of the aixing length and the canopy vind profiles a re presented along ith siaple scatter diagrans to sunarize the analysis of the codel data. (Auth.)

MODEL TY PB: nechanistic

C CHEEN T: Hodel is for basic research of air flov through regetation and propldes insights in to factors influencing aicrocliate of

getation. May have some use in assessuent.

$\langle 45\rangle$

Collgado, H.C. and D. 月. Brown. 1975, A bio-photo-theral model to predict tassel-initiation tiae in corn (ZEA MarS L.). Agric. Weteorol. 15: 11-31.

ABSTRACT: A bio-photo-theraal nodel to predict ta ssel-initiation tiae in corn vas fornuled and tested using data obtained froe controlled-enpironment studies and fros field controlled-environient studis and frote experioents vith and without plantigg-date experibents ith ad without go netic factor. op an daily teaperature. photoperiod, tea ferature range and photoperiod, tew ferature range and a pretor rariables. The model uses the concept of dela froa the shortest tiee to tassel in itiation caused by sub-optimal predictor variatles deterained on a dally basis. The shortest time vas obtained with a man daily te ape rature of $25 \mathrm{deg}$. C. photoper iod of $10 \mathrm{~h}$ and temperature range of 0 deg. $c$ (constant day and night teoperatures). Bach of the se conditions yas considered to be optiaus. Rith the incorporation of the developent potential factor. the predictions from the potential factor. the predictions from the number of days to tassel initiation in the numer of days to tassel initiation in the field. There was an arerage devia growing-degrae-n ay and the O.S. Weather Bureau thernal unit aodels vere tested as predictors of tassel-initiation tio in corn using the sane field data. Hodfications to these nodels vith the inclusion of

photoperiod, derelopaent potential factor and coubination of botb vere also tested. The predictlons from the bio-photo-theral aodel vere found to be superior to the predictions aade fros any one of the theras 1 predictions made from any one of the therma un it oodels and their odifications. Mong the unmodifed thernal unit models tested, the corn-heat-unit aodel gave predictlons the grow ing-degree-day and lastly. by the 0. s. Deather Bureau model. The introduction of the developaent potential factor. photoperiod factor or both iaproved the prediction of the corn-heat-unit and the o.s. Meather Bureau wodels. Inprovenent is the gr ow ing-degree-dap was attalned only vith the introduction of the photoperiod factor. It $1 \mathrm{~s}$. in ad has demonetrated the possibilit. of st ad has demonetrated the possibilit. nf prediction of tassel-initiation tiae in ithin a reasonable practical level of ascuracy by the

MODE I TYPE: regression equations
connErT: Could be used to evaluate sone technology in pacts.

$\langle 46\rangle$

Collis-George. N. and H.D. Helville. 1975. Mater absorption by suelling seeds, I. constant surface boundary. condition. Aust. J. Soil Res. 13:141-158.

ABSTRACT: Recent analyses of water absorption by ocedo havo used a non-svelling nodel vith constant diffusioity and constant surface concentration boundary condition. A physically realistic lodification of such analyses is developed, vhere the spherical seed has the properties of norval sveling, nolsture content dependent diffusively. and a -oisture characteristic which is described by the double layer theory relerant to collolds under mechanical restraint. Analysis of this odel by a finite difference approxiation produces a relationship between linearized molsture content and dimensionless time which is appropriate to all spherical svelling is appropriate to all spherical svelling aterials. $A$ good ateh was obtained betreen this relat lonship and experimental absorption graphicaliy in diensionless form is applicable to any suelling syster, e.g. soil aggregates. Which satisfy nornal swelifing and constrained double la ver boundary conditions. The analysis gave values for the diffusirity of the seed silliar to. but larger than, those calculated fror non-sueli ing aodels. These are uch smaller than most values of diffusivity of solis in the arailable vater range. The nagnitude of the caxiaurate at vich a seed can absorb water relative to that which the soll can supply, predicts that for seeds enbedded in ost solis, the constant surface concentration boundary condition used by ost authors is condition used by cost authors is inappropriate. In terms of the swelling beharlour of ost solls, the swelling odel, inbibing seed enbedded in soil vill be subject to a rechanical constraint. (Auth.)

MODEL TYPE: mechanistic

COnHBN : Hodel is orlented core to basic

research than assessnent applications.

$\langle 47\rangle$

Connor, D.J., L.P. Brown, and M.J. Trlica. 1974. plant cover, light interceptlon, and photosjuthesis of shortgrass prairie - $\lambda$ funct lonal sodel. photosynthetica 8 (1):18-27. ABSTRACT: A functional aodel to describe the relationship betueen coanonity photospnthes is, leaf a rea inder, 1rradiance. abblent teeperature, and soil vater potential is proposed and tested with field data collected on blue grama (BOOTBLOUA GRACILIS Lag.), the doainant species of shortgrass prairie. It involves an assessuent of radiation interception, of photosynthetic response onder optious conditions, and the introduction of proportionality factors to introduction of proportionality factor conditions of ambient tenperature ond soil vater stress. The predictive performance of the odel is conpared uith that of several statistical odels derlved fros the sane experiaental data. The oultiple correlation coefficient of 0.76 for the fanctional oodel is highly significant (P less than 0.01 ). (Auth.)

MODEL TYPB: Eechanistic

ConserT: This grassland aodel could be adapted to evaluate environsental iapacts of energy technologies.

〈48>

Connor, D.J., and O. Cartledge. 1970. Observed and calculated photosynthetic rates of 


\section{APPENDIX A \\ Agricultural Models (continued)}

(48) conT.

CHLORIS GAYARA conanitles. J. Appl. Ecol. 7: $353-362$

ABSTPACT: Photosynthetic rates of ChLORIS Gayana (Phodes grass) comanitles vere calculated using athenatical oodels. The aodels relate using eathenatical codels. The odels re late to direct and diffuse radiation and to the distribution pattern of the foliage. by neans of photosynthetic response functions. The calculations are shown to agree with photosynthetic rates neasured gasonetrically ith a portable field chaber. Coanuties with a leaf area index greater than 2.5 can be adequately represented by a single. continuous, horl zontal follage layer. In a ge ne ra 1 odel, appropr 1 ate to a 11 connunities and capable of accepting aultivle

photosynthet ic response data, a consideration photosynthetic response data a consideration ande need only be speclfled in teres of the ancle need only bef layer, although the re is an angle per leaf layer, although the re 1 a suggestion in sone of the data, that the incorporation of leaf angle distribution ia proves the accuracy of the sathesatical ap proach in sove situations. (Auth.)

MODEL TYPE: iechanlstic

C CAMEH $\mathrm{T}$ : Could be helpful in photospnthesis assessnents.

<49>

Currye R.8. 1971. Dynanic siaulation of plant gr ovth - Part I. Developlent of a odel. An. Soc. Agric. Eng. Trans. $14(5): 946-959$ MODEL TYPE: vechanistic

C CHMET: Phpsiological research nodel that is not directly applicable to assessuent. The model has been further developed since this report.

$\langle 50\rangle$

Daynard, T.B. 1971. Character 12ation of corn (2E) HAYS L.) canopies frod measurenents of individual plants. Agron. J. 63:133-135.

ABSTRACT: Because of their distichous growth hibit, the foliage structure of individual corn (zEA HaYs L.) plants can be diagraneed corn (ZE HAYs L.) plants can be diagraned by placing then against a flat surface and outining leaf positions on the surface deans of a marking pencil. A oethod is described vhereby asurements ade in such predict the canopy characteristics of ldentical corn plants in varlous plantiag arrangements. The progran output Includes quantitative two-diaensional descriptions of plants placed in different row-vidth planting patterns, plus a measure of the leaf area nd leaf angle characteristics of the various vertical layers of such canopies. Typical results with two conon hybrids are results With two con
presented. (Auth.)

presented. (Auth.)

c cHaent: yot directly useful but could be incorporated intc wore conprehensive plant modeling studies of canopy processes.

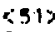

de Jager, J.N.. and J.B. Wallett. 1972. Effezt of moisture stress upon aize production and its econoaic significance. S. Mfr. J. Sci. $68: 182-186$

ABSTRACT: A matheatical model is established for deternin ing the tine of occurrence and nuaber of days of molsture stress experienced

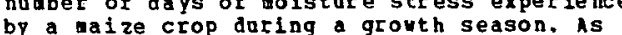
in put data the odel reguires values of dail in put data the odel reguires values of daily Doveton series soils 1.2 a in depth. Pield Doveton series soils 1.2 a in depth. Pield ca pacity of each of four soil layers nust kn ow $n$ and the anipulations account for varlations in root distribution with crop
developnent. The model has been conputerizad and applied to data fron three farning reglons in ratel. Expected average gross -argins for each area vere calculated. Otilizing a figure describing the decrease in final yield per unit stress day experlenced, it vas possible to deteraine the probability of accurrence of selected linits. (Auth.)

MODEI TTPE: paranetric

Conneut: Hodel requires enpirical data for study area. It is relatively simple in concept and could have vide application in assessent.

$\langle 52\rangle$

Duncan. M.G. 1971. Leaf angles, leat area, and canopy photosynthes1s. Crop Sc1. 11:482-485 than approxinately 3.0. differences in leaf angle are predicted by compter sinulation to hape only sall eftects on canopy have only sadil efrects on canopy har values. photospathetic rates. Por higher laI values. layers of vertical and horizontal leaves ca lovest possible rates of canopy

photosynthésis tót the conditions assulled. These arrangements. of leaf layers and angles are not nuch affected by leaf type or latitude within osual ifits. The ratio of highest to lowest photosynthetic rate varied fron 1.14 at IAI 3.0 to 2.0 at LAI 10.0 . calculations with one set of corn (2BA mas l.) descriptions indicate that canopy photosynthetic rates ay range fron $92 \%$ of theoretical axion at LAI 3.0 to $76 \%$ at LAI 7.0 .

MODEL TIPE: nechanist Ic

COHBAT: Hodel could evaluate energy technology effects on leaf area and leaf angle in teris of plant photosynthesis changes.

〈S3〉

Duncan, N.G.. R.S. Loonis, W.R. Milliass, and R. Hanau. 1967. A godel for simulating photosynthesis in plant connuities. Hilgardia $38: 181-205$.

MODEL TYOE: rechanistic

conarGT: An early uechanistic plant nodel that has been used as the basis of nore detalled has been lised as the basls of aore detalled in view of ore recent model avallability.

〈5u>

Dunhas, R.J.. and P.H. MYe. 1974. The influence of soil water content on the uptake of lons by roots. J. App1. Ecol. 11:581-595.

ABSTRACT: Opt ake and concentration gradients of chloride in soil in the vicinity of a plane of onion roots vere neasured at a range of soil vater contents. Uptake vas greater at higher vater contents, and the zones of depletion in the soll spread further fros the coots. A rolatively silple theoretical nodel roote. A relatively silple theoretical hodel trends anong the aesured concentration trends anong the aeasured concentration gradients - including an accomulation of chloride at the root surface in one case whe transpiration was comparativelg high. the vater content changes observed during the uptake period sat is factorily reproduced the general shape of the neasured gradients. but tended to underestinate the spread of the depletion zones. A possible reason for this vas that hydrodynamic dispersion by the vater flux to the roots increased the effective diffusion coefficient of chloride and thus increased the spread. Although, Ideally. the root absorbing pover used in the lodel should root absorbing power used in the model should have been continuously adjusted to take into account chloride concentration and atric potential changes at the root surface. the values uhich gave the concentration grad 


\section{APPENDIX A \\ Agricultural Models (continued)}

〈54〉 $\cos \mathrm{T}$.

gradients, agreed vell with the root

absorbing povers calculated fron the geasured

uptake. At higher scil vater contents the se

values of the root absorbing pover also

agreed with those obtained for onion

seedings growing in stirred nutrient

solution. At lower soll vater contents,

however, when the aatric potential at the

root surface fall to about -25 bar. the root

ab sorbing puder vas lowar (approx:
that for nutrient solution. (Auth.)

MODE Th T FE: nochanistic

COHA EN: Hocel considers one dinension uptake and is less useful than the work of Balduin, Hye and Tinker 1973 uhich considers cylindrical root sinks for solutes. This pa per contains useful data for onion.

〈55>

Dutt, G.R., M.J. Shaffer, and H.J. Hoore. 1972 . conputer siaulation aodel of dynanic

bio-physiochesical processes in solls. Technical Bulletin 196. Oniversity of Arizona, Tueson.

ABSTRACT: i digital conputer nodel uas developed to sinulate the effect of certain vironnental and nanagerial factors on soll-vater-plant systens. Pron an initial state and tie sequential input variables, the aode 1 si aula ted the non-steady state chenical, physical, and blological changes occurring in the unsaturated soil satrix and percolating vater. To denonstrate the usefulness of the sodel, a hppothetical problea of environuental concern uas sinulated. predictions for a period of thirteen years vere ade to assess the effect of three levels of fertilization on the content of water reaching the vater table. al 1 other factors vere held constant. In the problea considered, onl g the highest 10 vel of problea considered, only the highest level of content of the effluent frod the soil. content

MODEE TYPE: aechanistic

C CMARNT: Model contains considerable detail and is calibrated for soils of western OSA which are not strongly acid (pH > 6.5). Th1s work has considerable use for assessnent purposes.

$\langle 56\rangle$

Baglen an J.R. 1971. An experinentally derived aodel for actual evapotranspiration. Agrie. aodel for actual evapotrans

ABSTRACT: Experinental data frod several different clinat ic regions vere used to develup atatistioal aodol for actual water loss rates from land surfaces. The actual evapotranspiration rate was considered to be influenced by the amount of arailable vater in the soil and by neteorological and plant conditions which deternine the potential evapotranspiration rate. Experisental we asurenents of these three variables frod varlous environmental conditiong vere cobined into a single odel expressing the cosposite relationship. Actual cosposite relationship. Actual evapotranspiration rates vere calculated fro this relationshif using the variables soil mo isture and potential evapotranspiration.

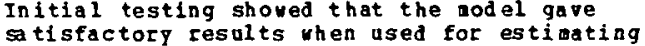
to isture changes in the ooil. (Auth.)

MODEL TYPQ: statistical

crnmpN?: Model could be used for the conditions tested. Considerable uncertainty exists for ot her applications.

$\langle 57\rangle$

Eckardt, P.E., G. Hein, M. Methy, H. Saugier, and B. R. Sauvezon. 1971. Punctioning of an ecosystem on the level of primary production weasurenents carried out on a crop of HELIANTHOS ANAOS. Decologia. Plantaru $6(1): 51-100$.

ABSTRACT: The functioning of an ecosysted - a HELIANTAOS AHAOS crop - is studied from the point of lieu of: (1) interception of radlant energy by the plant cover. (2) energy conversion in photosynthesis, (3) use of products of photosynthesis in building up of blonass. Wth special reference to radiant onorgy intercepting nrgans and (4) respiration involved in maintenance and growth enphasis being laid on effects of water stress on the se systen characteristics considered separately and as a whole. pour considered separately and as a wole. Pour aethods have been used: the energy balance control of the $C O(2)$ concentration. tenperature and huaidity of the aif, grouth analysis and wathenatical nodeling. Good agregaent of results is obtained when applying these nethods to the determination of carbon uptake by the ecospsten fros the lover atuosphere during the day. Variation about their poral values of various paraneters related to structure and functioning of the plant cover in sinulation experiments ith the odel made it possible to evaluate their role in net production. During the vegetative phase and until the end of flovering. dry atter production and fixation of che dical energy are proportional to the fixation of carbon: from then on. dry atter production is reduced and energy flration increased in relation to carbon fixation. Photosynthesis expressed as a function of leaf surface area is not affected by vater stress and no afternoon depression is observed, the plant reacting to drought by restricting leaf surface derelopeent. (Auth.) MODEL TYPE: mechanistic

connert: Conprehensive study using the de pit

(1965) odel for photosynthesis of leaf canopies.

$\langle 58\rangle$

Edvards, D.G.. and C.J. Asher. 1974. The significance of solution flov rate in floving culture experivents. plant soli 41:161-175.

A BSTRACT: Solution flow rate is an iaportant factor to be considered when designing or operating flowing culture equipent. A theoretical aodel is de veloped showing that the actal flow rate regulred for a particular experiment will depend upon man particular experient will depend upon ang factors, loportant asong which are and concentration of the lon under consideration, the quantity of roots absorbing the test ion under the conditions of the experiment. The results of experiwents conducted at lov concentrations of anoniua and itrate nitrogen clearly demonstrate that flow rates of the order of 1 litre per pot per anute or greater ay be required to prevent excessive depletion of the nutrient, solution. At lower flov rates. solution depletion resulted in substantial reductions in grovth and nitrogen aptake. quantities of nutrient solution reguired for experiuents at very high flor rates can be experimedts at very high flow rates can be reduced to practical levels by the use of in installations containing large nubers of potis. (Auth.)

nODEI TYPE: lechanistic

Conngat: Hodel applies to a flov culture regine that could be used in specialized assessuent studies.

<59>

glfuing. D.C. R. R. Kaufaan, and A. B. Hall. 1972. Interpreting leaf vater potential neasurements with a oodel of the 


\section{APPENDIX A \\ Agricultural Models (continued)}

<59> CONT.

so1l-plant-atmosphere continuua. Physiol. P1ant. 27:161-168.

ABSTRACT: A vaterflux nodel, which assunes that the dynaric functioning of the so il-plant-atsosphere continuun ay be de scribed by a series of steady states, was exanined as a aeans for interoreting leaf water potential aessurenents in inalencia. orange trees (CITR US SINENSIS (L.) Osbeck) or ange trees (CITR US SIRESIS (L.) osbeck). should be related to transpirat iona 1 flux. which in this experient vas estiaated by the which in this experisent was estialed at osphere to leaf diffusion resistanc (VPD/r(leaf)). Leaf vater potentials decreased in a specific relationship vith increasing values of $\nabla P D / r$ (leaf) provided that soil water was adequate and soil temperature vas not too loY. but ragh rd less of season of the year or cl isatic or edaphic ditterefices atong 3 field locations. When soil vater tensions exceeded 0.3 bar or whe soil temperatures vere lower than 15 deg. $C$. soil temperatares vere lover than 15 deg. C. deviations frod the nodel occurred in the for of more negative leaf vater potentials than prediczod by porr (lear). The Hodel predicts froa sieple easurenents made on intact plants that these differences we re 1 ue to the modification of flow resistances by cool te peratures and the codification of both resistances and the potential of vater at the source in the case of soil vater depletion. The nodel mag be a useful tool for interpreting plant water potential dat a under contrasting environeental conditions. (Auth.)

DODEL TYPE: nechanistic

CCABEN T: Could be used to exanine plad vater potential re gpon se to changes in environiental conditions induced by an energy technology.

$\langle 60\rangle$

Enfield. C.G.. and B.E. Bledsoe. 1975. Rinetic model for orthophosphate reactions in inera solls. EPA $660 / 2-75-022$

ABSTRACT: This stud 7 showed the reaction of phosphorus with nineral soils is not instantaneous. Thus, using equilihriu is otheras will yield erroneous conclusions as to the ability of a soll to sorb phosphorus. The sullablilig ur severai Riner ic adeis describing describing phosphorus reactions in evaluated, a alfusion-linted process paralleling heat flov theory for the storage paralleling heat flov theory for the ef herimental data. Combining the kinetic wodel with a ass balance equation, one should he able to accurately predict the uf scible displacenent of phosphorus through oineral soils. (kuth.)

nODPL TYPE: mechanistic

C ConEv T: Could be used in evaluation of wa stevater disposal on 1 and.

$\langle 61\rangle$

Enflela, C.G.. ana v.c. Shev. 1975. Conprison of two predictive nonequilibriue one-diaensional odels for phosphorus sorption and aovenent through hosogeneous soils. J. Envircn. Qual. a: 198-202.

ABSTRACT: Tro wodels vere tested for their ability to predict phosphor us breakthrouyh curves. The basic difference between the tuo models is the method of describing the kinetics of sorption. It was found, when couparing theoretically predicted i breakthrough curves vith experiaental breakthrough $c$ urves, that the adel using a kinetic equation itb power coefficients kinetic equation With power coefficients data than a first order rate equation.
(Autb.)

MODEL TIPE: echanistic

COABEAT: Dseful results showing that a kinetic phosphorus sorption odel should be included in soll cheaical transport siaulators. The sorption odel reguires enpirical constants. This oodel could be applied in sone

technology assessuents.

〈62〉

Paveett, R.G., and O.G. Carter. 1973. Otility of a siaple scil vater budget wodel in agronoaic research. I. Effects of plant density, tise-of-sowing and fallow vater on avallable soil vater under spring wheat. Aust. J. Expt1. Agric. Anid. Rusb. 13:714-717. ABSTRACT: A simple soil vater budget sodel was used to estimate veekly changes in arailable Qpil vator ao affeoted by plaul deuslty, tise of Soving and ion of orailablo fallow vater or spring wheat cultivars grown on a black ralues of avallable vater vere costly vithin. plus or inus 10 of observed values (ranging rou $50-270$ al obtainad (Eaging trou $50-270$ a) nhtainad at. fons results are discussed in relation to both the interpretation of agronowic fleld experients and use of the model in reglons where conserved fallow vater contributes significantly to cereal production. (Auth.) NODEL TYPE: statistical

COnART: Hodel tuned to Australian conditions. probably not suitable for assesseent under oSA conditions.

<63)

Favcett, R.G., and O.G. Carter. 197a. otility of a simple soll water buaget model in agronoulc research, III. Estination of the potential evapotransplration function. Aust. J. Expt1. Agric. Anla. Husb. 14:684-688.

ABSTRACT: It has been shown that a regression equation relating the cusulative potential transpiration function ( $T /$ Bo) vith the rield of tops, veek of sowing and arailable fallor nofsture, together with a siaple budget model, can be used to cstiaate veekly changes in available soll water under a wheat crop. It is concluded fro the data that use of the equation and budget odel shnili he nnst sulted to situations uhere plant densities are about 60 plants per n** 2 and the ace about 60 plants per
avallable fallov 2 ater is about 150 ar or less. (Auth.)

MODEL TIPE: Statistical

COABET: Hodel is tuned to Australian conditions. Probably not suitable for oSA
but the approach could be applied in the OS.

(64)

Peddes, R. A., E. Bresler, and S.P. Neuand. 1974. Pield test of a odified nunerical oodel for vater uptake by root systens. Nater Resour. Res. 10:1199-1206.

ABSTRACT: Data obtained fron careful vater balance studies on unter uptate by tbo cooto f cal cabbage are conpared with results btained fron aodified nuverical nodel of Nimah and lanke. In the rodified nodel the air dry moisture content at the soil surface ay vary uith tine depending on neteorological conditions. The naxiau possible rate of evapotranspiration is calculated by considering both neteorological conditions and crop properties. Data. are quoted to suggest that the coefficient of the root sink ay soneties vary exponentially vith depth. A period of 7 veeks vas sioulated, and the calculated weekly moisture profiles did not agree cospletely uith those profiles did not agree cospletely with those the calculated cualative rates of. 


\section{APPENDIX A Agricultural Models (continued)}

<64> CONT.

evaporation and transpiration were in excellent agreenent with the field data. When the original acdel was used without the suggested lodifications, the agreesent of these rates uith the field data was not as good. an indication that sone of these modifications actually inprove the predictive capabilities of the nodel. (Auth.)

NODEL TYPE: nechanistic

CCHABT: This is a research sodel that could be adapted to evaluate effects of an energy technology on field water dynamics.

<65>

Perry, R.A., and R.A. Olsen. 1975. Orientation of clap particles as it relates to crusting of soll. Soll Sci, 120:367-375.

ABSTRACT: sinple oodel for a soll crust was foraulated and experilentally tested. It is based upon the parallel orientation and close packing of clay particles perhaps like that in shale. The physical and chenical factors which discupt the ordered arrangevent of the plate-shaped particles vere noted to be those which induce aggregate formation and wich result in good soli structure. The faztors which induce greater or lentation and packing vere noted to be those which induce crust formation and poor soll structure. The formation and poor soll structure. The geralnation, aolsture penetration and runof aeration, and penetrability to roots are veli knovn. Experiaental attenpts vere ade to test the validity of the proposed odel. In each instance, the data either provided support for the oodel or else could be resonably reconciled uith the model. The aodel appears to provide a reasonable basis for explaining cultural practices which are knoun to lafluence soll structure in either be neficial or deleterious ways. (Auth.)

HODEL TYPE: echanistic

CONMEN $\mathrm{T}$ : Could be used espirically to evaluate crusting effects of energy technology effluents.

<66>

PerY, R.L. , and J. Janick. 1971. Response of corn (ZEA MAYS L.) to population pressure. Cr Op SC'1. 11:220-224.

ABSTRACT: The response of field and sueet corn (ZEA MAYS L.) to population pressure vas investigated using square and rou spacing arrangenents ith population levels ranging frow 2,375 to 151,957 plants per ha 1961 to 61.496 plants per acrel. Grain pield per 61.496 plants per acre) infaln gleld per level. while total top yield a ppeared to be asymtotically related to plant population. of the rarious models tested only the "modifled reciprocal" adeguately described the respense of both grain and total top yleld per plant to changes in plant density. one enpirical constant can be estiated fron pield changes wi th plant density. Another piela changes wi th plant density. Another criterion in breeding for increased pield and as a parader in population and plant distribution studies. (Auth.)

MODE L TYPE: regression equation

COHAET: Empirical function fitted to field experimental data. night be useful in a crop ef fects on plant density.

<67>

Pick, G.R., R.A. पillians, and R.s. Loonis. 1973. Computer si wulation of dry natter distribution during sugar beet growth. Crop Sc1. 13:413-417.

ABSTRACT: Seasonal growth curves of sugar beet (B BTA POLGARIS L.) vere simulated by a CSMP conputer nodel called SUBGRo. The hypothesis on which the simlations vere based was a hierarchy of priorities for photosynthate partitloning. In order of ileportance, these priorities vere as follows: respiration, top growth, fibrous root grovth, and storage root grovth including sucrose accugalation.

giaulations a greed vell vith field

observations ven these priorities vere used. observations when these priorities vere observations if the seguence vas changed. The rate of use by each sink was further regulated by its growth potential and by its environeent. Punctional leaf and

fibrous-root surfaces played key roles in regulating the grouth rates through a

quantitatively expressed set of partitioning functions. To test the partitioning

hypothesis, simulated recovery patterns fron

partial defollation or root pruning vere con pared to experimental observations. conpared to experimental observations. Siwulated recorery was
real. plants. (Ruth.)

nODEL TYPE: nechanistic

COMABN: Hodel used to test h ppothesis about plaat growth. The tested codel could for the basis for evaluation of pollutant or

$\langle 68\rangle$

Piscus, E. L. 1975. The interaction between osmotic- and pressure-indaced vater flow in plant roots. Plant Physiol. 55:917-922.

ABSTRACT: This paper presents a general odel for coupled solute and vater flou through plant roots based on the thergodynamics of ifreversible processes. The nodel explains is a straightforvard anner sucb exper leentally observed phenonena as changes in root resistance, increased solute flux. and apparent negative resistance, which have been reported for root systems under the influence of a hydrostatic pressure gradient. These apparent anonalies are explained on the basis of the interaction betreen the the basis of the interaction betveen the oswotic and hydrostatic driping forces and the vell knoun "sweeping avay of dil bydrauife conductioity the only features necessary to explain these phenonena are sone type of wembrane or nebranelike structure and a manisa for actively accuaulating solutes. (liuth, )

HODEL TYPE: Nechanjstic

COAHENT: Hodel is used for theoretical analysis and is not readily adapted to technology ass essment.

<69>

Pltzpatrick, E.A., and H.A. Nix. 1969. A codel for siaulating soll water regise in alternating fallow-crop systeas. Agric. Het eorol. 6:303-399.

ABSTRACT: In developing a sethodology for quantitative agrocilatic assesseent within a sub-huaid to seai-arid region in central oueensland with sparse weteorological and agrononic data, a set of siaple vorking functions depicting evaporative losses of an functions depicting eraporative losses of Given veekiy rainfall and estiates of potential evaporation as basic inputs. these fanctions are used to generate a continuous siaulation of veek-to-week changes in joil vater. Despite data inadequacies, a close sinulation of tenporal changes in soil vater regine was obtained using distinctive functions for falloved and cropped intervals. functions for falloved and cropped int and by aring eva potranspiration rates dependent upon stage of crop developaent and status of available soil water obtained as stepped functions used in the model to express evaporative loss juring falloved and 


\section{APPENDIX A \\ Agricultural Models (continued)}

<G9> cont.

cropped intervals vere fitted in part by ap plying prepious functions presented by si atyer (1960b), and in part by 1terative deterained by gravinetric sapling and phenological data fron an experimental site ithin the region. Sufficient data vere available to enable the formulation of functions for cotton, grain sorghum, and functions for cotton, grain sorghun, and theat. The nodel takes account of prevalling agronouic Fractices and dynamic a spects provision for future refinevents in a vailable data. (Auth.)

MODE L TYPE: paranetric

COnHEN T: Hodel could forn the basis of an assessment odel with the introduction of appropriate response functions.

$\langle 70\rangle$

Pogel. M.n., L. Duckstein, and C.C. Kisiel. 1974. Modeling the hydrologic effects resulting fron 1 and oodification. Trans. of The $A G A B 17,1006=9090$.

DOBge TreE: pacametrlo

C CHAEN T: Technology effects on land use change and $h$ pdrologic consequences could be examined.

<71

Pcllett, R.P., R.R. Allmaras, and G.A. Re ichan. 1974. Distribution of corn roots in sandy soil with a declining vater table. Agron.J. $66: 288-292$.

ABSTPACT: The purpose of this study vas to relate the distribution of corn (ZEA MaYs L.) roots to depth of declining water table in a sandy cos association. nnovledge of root a sandy sol association. Rovledge of respanse to declining water tables ls iaportant for proper crop production $199 \mathrm{~cm}$ managent. Roots fron 10 monoliths (99 rm dsep). Centered over and perpendicular to the corn rov, were obtained at about full silk a ter table depths ranged fion 1.33 to 2.64 . at stlking after declining at the rate of about $1.3 \mathrm{calday}$ since July 1 . About $20 \mathrm{x}$ of the evapotranspiration was suppiled by natural frecipitation with the renaining $80 \%$ from soil vater depletion and the vater table for the feriod $f$ ro July to septeaber 16

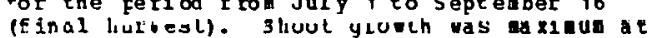
interaediate water table depths. An equation intervediate water table depths. An equa describing root distribution vas obtained function of water table depth ( $x$ (1) and function of water table depth (x (1) and culalitie root veight $(x(2))$. A sillar was wade using root length as $x(2)$ in no cas sas more than $10 \mathrm{x}$ of the total deasured measured root length below $75 \mathrm{ca}$. The distribution of roots with depth indicates wa ter requirenents for corn in these sandy soils must be supplied to a root zone with mxinum depth of about $100 \mathrm{~cm}$. Retarded root growth was otserved where soil oxygen diffusion rate $(0.0$. R.) vas less than 26 g/c**2/10**8 ain. Such O.D.R. vilues vere ob alned at depths greater than $30 \mathrm{ca}$ at the shallow water table site. Apparent noral root development occurred when o.D. R. values root de greater than $30 \mathrm{~g} / \mathrm{co*} * 2 / 10 * * 8$ ain and were greater than $30 \mathrm{~g} / \mathrm{co} * * 2 / 10 * * 8$ ain and
matric suctions vere about 100 b. (Auth.) MODEL TYP: regression equation

C CHMEN T: punction fitted to experisental results could te used in wole plant wodel.

$\langle 72\rangle$

Prenkiel, F.N., and P.S. Rlebanoff. 1975. on the lognornality of the small-scale structure of turbulence. Bound. - Layer neteorol. 177-200.

A BSTRAC?: Gigher-order noments of turbulent velocity gradients and their behavior with Reynolds number vere measured in the nearly isotropic turbulent field generated by a square-esh grid and in turbulent boundary layer along a flat plate ith zero pressure gradient. Hot-wire anemonetry and instrumentation cobining analog and digital -ethods uere used to besure aodents up to the fourteenth order. Heasurements of such high-order monents required that particular attention be givon to their validity. attention be givon to their validity. effects as nonlinearity, averaging intervals, and the adequacy of the statistics for the tails of the frobability density

distributions. The results obtained are conpared ith those of other investigators for a variety of flow configurations in the laboratory as vell as in the atmosphere. The concept of the internittency of the

swall-scale structure and the theoretical

approach involving lognormality of the

probability density distribution of the

dissipation rate are evaluated. (Auth.) MODEL IY PE: mechanistic

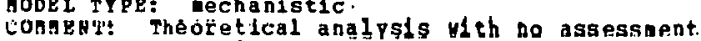
appitcation in present fora.

〈73>

Prore, M.ll., C.A. Onstad, and H. H. Holtañ. 1975. an agricultural chenical transport nodel. ARS-H-3, Agric. Res. Ser.. OSDA.

ABSTRACT: The use of chemicais is an important feature of modern agriculture, but the novenent of the cheaical from its point of application constitutes a potential hazard. The evaluation of this hazard is rery. difficult because the agricultaral watershed contains any conplex processes that contains aany conplex processes that ald in evaluating this hazerd, a eatheatical model has been developed and a computer progran written that describes the movenent of chenicals in and across an agricultural vatershed. Por each store in series the objective is to use the nodel to predict the concentration of a cherical in the runoff vater. the total anout cascied by the ranoff vater and sedinent, and the location and concentration of the chenical reasining on the vatershed. This report describes the rationale used to develop the aodel as vell as a couple of tests of the odel that illustrate and eraluate its use. (1uth.) nODEL TYPE: paraetric

HODEL TYPE: paranetric
COHAER: Very useful in assessuent of pollotant transport frol technology sources. The chealcal transport has been added onto the hydrologic sinulator of Holtan and Lopez (1971).

$\langle 74\rangle$

Pricsel, MoJ., P. Poelstra, and P. Relniger. 1970. Chronatographic transport through soils, III. A sinulation nodel for the evaluation of the apparent diffusion coefficient in apdisturbed soils with coefficient in andisturbed soils with

ABSTRCT: $A$ siaulation odel, written in CSAP. is described pereitting the calculation of chron ntographic transport in heterogeneous systens like soils. Breakthrough curves of tritlated vater vere deternined on und isturbed, vater-unsaturated soll colunas (100 calength, 12 cadian.). With the nodel, tortuosity and disporsion factors vere cal culated for three solls - a sand. a clay and a loess. The mean values for the tortuosity vere $0.3,0.2$, and 0.2 and for the dispersion $0.7,0.8$, and $5 \mathrm{ct}$, for the three soils respectively. Pron these values it appears that usualiy dispersion is the nain appears that usualig dispersion is the ain soil, the contribution of ionic diffusion 


\section{APPENDIX A \\ Agricultural Models (continued)}

〈7a〉 CONT.

being rather saall. In any cases good approxiative values of the dispersion cofficient ay be obtalned uith an an alptical solution of the chronatography equation assuning an areraged homogeneous system. ' liuth.

\section{MODEL TPPE: mechanistic}

COnE T: Could be aseful in testing protocols for poll ntant cheaicals from enerqp technologles.

<75>

Gates, D.H. 1965. EnergY, plants, and ecology. Be $0109 \mathrm{l}$ $46: 1-13$.

A BSTRAC?: The environgental factors affecting the flow of energy betveen a plant and its environment are described. These factors are solar and thermal radiation, alr taperature. vater vapor density of tho air. and vind so eed. The rechanisus of radiation. convection, and transpiration which transfer energy between the plant and the environgent are expressed in analytical fora. An example is given of a 24-hour cycle for a plant il lustrating the dally variation of each of thise factors and of the resulting plant temperature. Basic plant propertles, such as te werature. Basic plant properties. absorptance to radiation, convection coefficient, and water vapor aiffusion resistance, deteraine the exterit to which the environaent influences the energy content and te nperature of the plant. Photosynthesis is physiolcgical processes a re teaperature dependent only. Maxiag and ainiag in photosynthetic activity occur during a day as a consequence of changes in light latensity and leaf te we rature produced by parying environaentai conditions. The ecological significance of these enpiconeentally in fluenced physiological processes is in fluenced phpsiological processes ta enornous in teras of
coapetition. (auth.)

noph a

C CHAENT: Basic principles of energy transport and transformation. Work can be adapted to evaluaticn of technology inpacts.

$\langle 76\rangle$

Gervitz, $A$. and E.R. Page. 1974. An enpifical we thatical oodel to describe plant root ST stens. J. Appl. RCol. 2(2):773-781.

A BSTRACT: A surveg has been ade of the literature in which the root systems of vegetable crops, cereals and grasses have hep in instigated by qajious techniques, he en inqestigated br various techniques including excavation and the use of undioactive tracers, an eapirical aodel vas used to standardize the data. One form of the model is $-P=100 *\left(1-e^{* *}(-f x)\right)$
$P$ represents the percentage of roots copresents the percentage of roots pa ramete. such that $1 / f$ is equal to the depth of soli which contains $63 \%$ of the total root mass. The effects of soil noisture. fortility, plant age. veight and species as $f$ are considered. Seventy one out of the 101 se ts of data fitted the aodel ver satisfactorily. It is expected that the satisfactorily. It is expected that mathesatical odels to siulate plant growth. wa the sats

NODE L TPPE: regression equation

ConH $T$ : Derived functicn could be used in vole plant grouth nodels.

$\langle 77\rangle$

Gibert, 0.1. 1970. A blologlcal scale for the estimation of sulphur dioxide pollution. Hev Ph ytol. 69:629-634.

ABSTRACT: By observing the distribution of lichens and bryophytes in an area where levels of So(2) are well known it has been possible to produce a scale fron vhicb annual arerage levels of this pollutant can be arerage levels of this pollutant can be scale are given and its accuracy and possible usefulness ar e discussed. (Ruth.) nODEL TYPE: response of indicator plants conART: Oseful field survey tool.

$\langle 78\rangle$

Ginsburg. H. 1971. Hodel for iso-osnotic vater flow in pla

ABSTRACT: The different interpretations of iso-osnotic ater flou in plant roots are
revieved and a model based on the syaplas. theory is proposed to explain this phenonenon theory is proposed to explain this

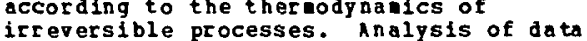
fros the literature with the model lead to the following conclusions: (1) different reflection coefficients (sigma) at the s yaplast boundary neenanes are sufficlent to account for the invardly directed iso-osnotic water flov observed in aaize roots: (2) the difference between the hydraulic conductioities (Lp) and the difference between signa ip at the boundary reabranes can ef'ther increase or decrease iso-osatic water flow depending on external conditions (1.e. hydrostatic pressure. concentration of (1.e. hydrostatic pressure, concentration of peraeable and impermeable solutes); (3) physiological data fros the literature and it also explains how aetabolise is involved in iso-osnotic water flov. The probable leportance of iso-osnotic water flow for whole plants is briefly discussed. (Auth.) MODEL TYPE: sechanistic

ConmENT: Detailed odel of cellular processes that is not sultable for technology ass essaent.

$\langle 79\rangle$

Govdriaan. J., and P.P. Maggoner. 1972. Simulating both aerial acroclinate and soil teaperature from observations above the fol iar canopy. Neth. J. Agric. Sci. $20: 104-124$

ABSTRACT: A sinulation sodel is described 'for the daily course of aicroclinatic characteristics of foliar canopy and the soil underneath. The independent driving forces are the meteorological observations above the canopy. The canopy is described by its geosetrical, optical and physlological properties. the soil by its thernal and

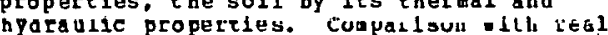
hyaraule propereles. cuapal sul -ith transpirat transpirat 10D. Soil evaporation and temperature and hunidity and leaf teaperature. The siaulations, covering a fuli day, vere executed with a stratified nodel. The effect of stratification uas investigated ty a comparison with a nodel continuous in height. (Auth.)

MODEL TYPE: vechanistic

conuER: Very useful oodel that could evaluate aicrocliate changes induced by technology.

$\langle 80\rangle$

Green, R.E.. ànd J.t. Corey. 1971 . Caleulatiun of hydraulic conductivity: $A$ further evaluation of sose predictive vethods. Soil Sci. Soc. Am. Proc. 35: 3-8.

ABSTRACT: A couputational wethod based on the pore-interaction odel of harshall was shoun to conpare favorably with modified nethods of nil ington and Quirk and of Marshall for prediction of hrdraulic conductivitg os. vater content on a numer of soils and glass bead systea. All sethods required 


\section{APPENDIX A \\ Agricultural Models (continued)}

$<80\rangle \cos T$

atching one point on the calculated hy draulic conductivity curve to an experimentaly measured hydraulic conductivity value. The calculation aethod ajequately predicted the experinentally measured values and provide satisfactory conductioity data for any applications. An ad vantage of the proposed nethod is its independence of the value chosen for the exponent on the porosity tere in the prediction equation. (Ruth.)

CODE TrPE: echanistic

CoMAB T: The cethod is useful in soll water flov mode is $f(c)$ representation of soil hidraulic properties.

$\langle 81\rangle$

Gregorlus, H.R.. and G. Huller. 1975. Genetic structures in finite, open-pollinated plant populations: model and its application to seed orchards. Theor. Appl. Genet. $46: 295-305$.

ASTRACT: lodel has been constructed to investigate the conseguences of the rate of se lf-fertilization, pollen-dispersal. populaticn-size, and number of clones on the genetic structure of finite seed plant porulations. Derivations have been perforaed for tvo different cases: (A) Parental genetic structure explicitiy given: inferences for the expected genetic structure of the resulting seed population: (B) Extension of case $A$ to several non-overlapping generations. If $r$ andoa cross-fertilization is assued for ca se $A$ the genetic conposition does not change and the ge netic distance betveen the correspond ing ge netic distance betveen the chespected of fspring-structure is 0 if the rate of of fspring-structure is 0 if the rote self-fertilizaton is equal to $1 / \mathrm{N}$
$(\mathrm{N}=$ popolation-size): an deviation from $1 / \mathrm{A}$ (N=population-size): an $\mathrm{g}$ deviation from 1/N ca uses an increase in genetic distance. In case $B$ the expected genetic structures have ossible to for all generations a nat siople de pendence on the coefficient of inbreeding. In addition the pariance of the

al lele-frequency has been presented. A11 the al lele-frequency has been presented.

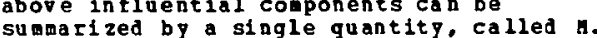
sumarized by a single quantity called a Af ter proving that 1/h can be conceived results obtained could be presented depending on this effective size and the average rate of self-fertilization only. Applying the findings of the nodel to the situation ra alized approxiately in a seed-orchard. the following staterents can be wade: Case (A) Aqain assuaing randon cross-fertilization, a deviation cf the parental population frod the corresponding Hardy-Veinberg-proportions can. ith increasing rate of self-fertilizaton, be ex ceeded sy the respective deviation of the exceded ty the respective deviation of the sollen population. Case (3) The influence of pize has been investigated, assuaing no variation of the indiridual rates of self-fertilization, pollen and seed production within the population. Only extreae $1 y$ swall differences betveen effective and actual population size vere obtained. which indicates that the influence of poilen dispersal is of minor iaportance in this case. Pcr different rates of

self-fertilization. significant differences in the increaents per generation for the coefficieats of inbreeding. as vell as the frequency of hovozygotes, vere obtained for the first generatica only. Decreasing number of clones influences the rate of self-fertilization and the effective population size siauletaneously by increasing the first and decreasing the latter. This is tr ansferred to the coefficlent of inbreding. frequency of the homozygotes and the rariance of the allele-frequency by an increase of MODEL TYPE: statistical

MODEL TYPE: st at istical
COHANT: Theoretical analysis not sultable for technology assessent in present forn.

$\langle 82\rangle$

Grenetz, P.S., and R. List. 1973. A nodel for predicting growth responses in plants to changes in external vater potential: zBA hars priaary roots. J. Theor. B101. 39:29-45.

ABSTACT: In response to osnotic step changes. three distinct phases have been noted in the grovth response of 2EA hars prinary roots. Thep are cessation or slowing of growth over a period of 15-20 ainutes, tissue contraction, and a danped oscillatory retarn to nearly noral grouth rate, all vithin a period of about one hour. A systen nodel of the tissue response is presented to explain such behavior and to serve in a predictive capacity to govern future experiments. It $1 \mathrm{~s}$ supposed that for turgor pressure in excess of a cell vall yield threshold, plastic flov and that when turgor falls below yield threshold. elastic deformation is dominant. The equations of the oodel describe growth rate as a function of time in teras of the folloving properties; plastic flow. elastic deformation, permability to vater, and solute uptake. They are derived fron basic equations of feedback interactions betveen internal osmotic pressure and grouth rate. and between wall softening. turgor and grouth rate. The aodel predicts osclliatory grovth rate regulation, and phase and anplitude relationships betveen turgor pressure and grouth rate. The simplest oodel uhich accounts for all observations is that of biphasic deformation. tro odos of vali biphasic deformation, two oodes of vall involving osmotic and yield threshold control of growth rate. It should be noted that to predict the tine course of turgor pressure. oseotic pressure, lield pressure, and growth rate, tro initial conditions and siy syster paraneter ralues a re sufficient. So far only of growth rate and its derivative can be obtained for zEa mays prieary roots. Hoverer, values for wall softening and hardening coefflcients (including the strain and turgor independent component). plast ic extensibility, vater peraeability and dilution rate coefficients have not been obtained as yet for ZEA roots. values for sowe of these paraveters have been obtained for other roots, coleoptiles, and giant algal cells. Lest the reader despalr. it should be pointed out that experieental observations coupled vith sinulation studies vill help establish restricted ranges of values that the systen paraneters aight assuae. These can then be corpared vith known values in the literature and values known values in the literature and val experineat
(Auth,)

HODEL TYFE: mcchanistic

CHAENT: $i$ basic plant physlological hodel of doubtful application in technology assessent.

$\langle 83\rangle$

Hackett, C.., and D.A, Rose, 1972. A lodel of the extension and branching of a seminal root of barley, and its use in studying relations between root diaensions. II. Results and inferences fros anpulation of tbe nodel. Aust. J. Biol. Sei. 25:681-690.

ABSTRACT: model of root growth was used to investigate $v$ hy the average length (1) of cereal root neabers remalns roughly constant. Taking as a standard the model root which agreed with actual roots fron an experinent. 


\section{APPENDIX A \\ Agricultural Models (continued)}

<83> CONT.

the nine variables in the aodel vere altered singly tc see which had greatest influence on 1. The results shoved that the constancy of 1 vas due priarily to the existence of ceilings to the rates at which each class of root menter can extend. These ceilings a re thought to be deterained by a property associated with the dianeter of the root mober. Also of inportance as the timing of the onset of each order of branching. This timing was related to that at which the parent menbers, as a population, began to increase roughiy linearly in volume. A tentative explanation of the concouitance is put forvard. Inderstanding of the phe nomenon vas advanced by the study, but a full explanation was not achieved, ainly because of the lack of information about certain as pects cf root developent. (Auth.)

MODEL PYPE: wechanistic

CCMAEN : Model evaluates plant physioloqical behavior of roots and is not readily applied to technolog $\mathrm{y}$ assessment.

〈Bu>

Hacket t, C., and D.A. Rose. 1972. A model of the extension and branching of a seaina 1 root of barley, and its use in studying relations between root dimensions, $I$. The aodel. Aust. J. Biol. Sci. 25:669-679.

BSTRACT: previous papers have reported that relations betveen the total number, length, surface area, and volume of graminaceous root me mbers tend to rewa in roughiy constant du ring vegetative growth. Through the use of a model of the extension and branching of a se winal root of barleg (HORDEUn VULGARE L.). which was de veloped for the purpose, an at tempt has now been ade to deteraine the properties of root grouth responsible for the phenowenon. The present paper introduces the study and describes the model. The nodel takes advantace of the fact that the takes advantace of the fact that the we mbers groun in hooogeneous wedia prozeeds at approximately constant rates for lengthy periods. The overall dinensions of roots can therefore te deterained by reference to forwalae representing time and a limited nu wher cf properties of each type of root member. The validity of the model for the use intended is dewonstrated by testing the underlying assumptions and checking the nodel against actual data. Other possible roles against actual data. other possible roles series (Backett and Rose 1972) reports the results and inferences from manipulation of re sults and inference
the podol. (Auth.)

MOREL TYPR: nechanistic

COMA EN: Hodel describes root grovth a nd through change in parameters, environaental effects could be simulated.

$\langle 85\rangle$

Hanks, R.J. 1974. Hodel for oredicting plant vieid as influenced by ater use. Agron. J. $66: 660-665$.

ABSTRACT: A model has been devised to predict pl ant pield, both total dry matter and grain. as a function of water use. The model is simple and inexpensive to $r$ un on a conputer to determine seasonal yields as influenced by irrigaticn frequency and awount, rainfall. and suil water storage. A good fit of predicted $\nabla 5$. measured dry natter yield of sorghum (SORGROM VOLGARE L.) in Colorado, corn (ZEA MATS L.) dry matter a nd grain yields in Israel. and corngrain pields in yielas in Israel, and corn grain qlelds in treatments. was found. A basic assumption is that the ratio of actual to potential dry matter yield is directly related to the ratio of actual to potential transpiration.
Evaporation from the soil is assuaed to decrease with the square root of tine after vetting as well as with the stage of grovth. The shape of the relative 7 ield-uater use curve as found to be sensitive to the evaporation and transpiration assunptions aade, but insensitive to the relation used to describe the influence of soil water status on transpiration. (Auth.)

MONEL TYPE: parametric

COHHENT: Empirical model with broad application to technology effects on crop production. could be readily adapted to evaluate irrigation with bloudoun water, although salinity effects vould need to be included.

$\langle 86\rangle$

Hansen, G.K. 1975. A dynanic continuous simulation model of vater state and transportation in the soil-plant-atoosphere systen. I. The odel and its sensitipity. Acta, Aric. Scand. 25:129-149.

ABSTRACT: Through a continuous sioulation oodel. a spnthesis of quantitative interrelations of ater state and transportation in the soil-plant-atmosphere system is described for a grouing crop under realistic field conditions. In the model, vertical water flux in the soil is based on Darcy's law for flow in porous mejia. Hater flow is based on single roots, but odified to steady rate. The physiological plant parameters are based The physiological plant paradeters are based atwospheric part of the model is based on the Dodel of Monteith (1965). The model is vritten in DPNAHO II. The simulation runs. with a fixed time interval of 0.001 day. The behaviour of the model is denonstrated by a grovth period of 20 lays wi thout precipitation. Results of the simulation are shoun for two different soils and at three values of evacorative deand. It is concluded that the model is able to predict vater state and ater flow in soil and plant. quantitatively as ell as qualitatively.

NODEL TYPE: Eechanistic

ConkENT: Model is research oriented and expensive to run. Not recomended for ass essient.

$\langle 87\rangle$

Hari. P. 1972. Physiological stage of development in biological models of grouth and aturation. Ann. Bot. Pennici 9:107-t15.

ABSTRACT: Time is frequently used to describe the derelopmental stage of a plant or animal in biomathematical models, However, there is often a notable discrepancy between the chronological age and 'the biological age' of an organisa, oring to different rates of developwent under different environnental conditions. In the present paper a variable is defined that should serve better than age to denote the stage of development. The physiological stage of developnent defined here can be used to construct and test various hypotheses concerning grouth an various hypotheses concerning growth and
development. As an example, an application of the physiological stage of developwent to a wathematical model of the daily increment of pine seedlings is presented. The sane variable (physiological stage) should be equally useful in many other biological models. (Auth.)

MODEL TYPE: para metric

ConnENT: Empirical model that can be used in comprehensive plant podels to represent plant development.

Harris, G.P. 1972. The ecology of corticolous lichens, III. A simulation odel of 


\section{APPENDIX A \\ Agricultural Models (continued)}

$\langle\theta \theta\rangle$ CONT.

productivity as a function of light intensity and vater arallabllity. J. Ecol. 60:19-40.

ABSTRAC?: A aathenatical siaulation adel for predicting epiphytic corticolous licben productioitg has been bullt relating lichen productivity to environmental conditions at Shaugh, S. Devon. Net carbon assimilation rates vere calculated for PARALIA CAPERATh (L.) Ach. at six helghts in a nodel oak tree,

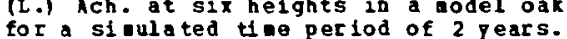
for silula ted tioe period of 2 pears. calculted for lichens at each height. The nodel has been constructed as a serles of nodel has been constructed as a serles of blocks each of which relates to, and was blocks are as follows. (a) hain progra ro sponsible for setting up arrays, reading da ta and calling subroutines. (b) Radiation intensity subroutine - using input paraseters of time of year, tine of day. cloud cover and radiation drop inside the tree canopy:

radiation levels were calculated for each of the six height the six height zones in the tree. (c)
Hetting-up gubroutine - rates of vetting of different parts of the tree during rain vere observed in the field using paper-grid coserved in the field using paper-grid conductioly sensors and a portable chart recorder. A nev technique for wodelling rainfall/througheall vas used to simulate the wetting-ap systen and was tested agalnst observed data, vith good a greenent. (d) Measureaents of eraporation vere carried out in the field using the paper-grid conductivity sensors and sall capillarp evaporimeters. Calculations of evaporation by Penuan's method were used to estiate evaporation rates froa the entire tree canopy. varlous nethods of apportioning the evaporation rates ithin the canopy are evaporation rates ithin the canopy are physlology are based on dat a published in a previous paper in this series. The odel appears to give a calculated result which conpares favourably uith the vertical distribution of P. CAPERATA measured in the field. variation in veekly net carbon assiailation totals are shoun to be highly variable and are thought to be correlated with vater availability in the environent. changes in the vertical evaporation gradient are shown to have a strong effect on the verricai ulstivut lua uf this suecles. (Auth.)

Modi uth.)

C CHABN?: Oseful aod that could be adapted to simulate pollutant effects. Results could be compared with field surveys of lichens which are good pollutant indicators. This codel ho 3 indirect application to technology in paces on ayrleultulal ecusgsteas.

(A9)

Heck, M.N.. and D.T. Tingey, 1971. Ozone. Ti ae-concentration model to predict acuto, foliar infury. proc. Second Int. Clean ir congr., Fp. 249-255, Acadenic presss, Ney Congr.

nunx Ty: paranotese

COHERT: in eguation vich predicts acute ef fects cf pollutants on plants where both ti we and concentration are independen variables. Relationship could be included in nore conprebensipo plant odels.

<90>

Heluy, A.R.. Z.A. Perrelro, and H. Peinenann, 1975. Plant roots as aulti-zonal 1 eabrabes. z. pflanzenphysiol. 76, S: 294-299.

ABSTRACT: By using plant roots of barley, wheat, tall heatgrass, peas and cucumber as the same $\mathrm{KCl}$ concentration is placed on both sides of tha root. It vas found that for all the plants the masured electric potent lals are positive at low RCl concentration, they becoae negative at high KCl concentration and van ish at an internediate rel concentration. The data could be erglained by a theoretical nodel that treats the root as a enltizonal

-en brane, i.e. composed of zones vith different electrocbealcal properties. (huth.) GODEL TIPE: eechanistic

COBAERT: Basic plant physiological hodel with no application to assessment at this stage.

$\langle 91\rangle$

Hea, J.D. 1976. Geochenical controls on lead concentrations in stream water and sediments. Geochin. Cosmochin. Acta 00:599-609.

ABSTRACT: The equilibrias distribution of lead in solution and adsorbed on cation exchange cites in sedinent theoretically ay be calculared rros quar 1 ons represeneing selectivities of substrate for lead over $H+, C a(2+)$ and $N a+$, and the stabilities of lead solute species. Such calculations include consideration of total concentrations include consideration of total concentrations
of ajor ions, cation exchange capacity (CBC) of ajor ions, cation exchange capacity (CEC) of substrate, and PH, at Values expected in and selectivity coefficients vere ade for spithetic halloysite, a finelg divided anorphous $1: 1$ clay prepared by precipitation from aixture of solutions of alualoun and silica. Where suspended sediment having the sawe properties is present in concentrations of 10-1.000 $\mathrm{mg} / 1$ at $\mathrm{pH}$ 6-8. wose than $90 \mathrm{~s}$ of the lead present $c a n$ be adsorbed on sedinent surfaces. The cation exchange bebarior of lead and other nor cationic species in natural eystens could be prodictod by this natural 6 gsters could be predictod by this inforation vere available. Information of information vere available. Information of sedinents. hoverer. is presently inadequate for accurate predictions. (Auth.)

MODEL TIPE: aechan ist 10

COMABT: Oseful oodel that wa have too auch detail for assessient purposes.

$\langle 92\rangle$

gexee, R.W.. V.A. Sposito, and R. O. Heady. 1976. Application of a tuo-variable Hitscherlich function it the añalysis of

pleld-water-fertilizer relationships for Fleld-water-fertilizer relationship
corn. Mater Resour. Res. 12:6-10.

ABSTRACT: Variations of lodels developed by $z . \wedge$. ritscherlich in the early part of this century are periodicalig used for estinating input-output relationships for plants. hit scherlich's rork focused on aingle - ar lable: Dlile lhese expoliential asdela incorporate features of theoretical appeal. the procedures for quantifying the lodels are relatively conplex uhen two or more independent 7 ariables are included. In fits of uitscherlich and polpnoalial fores to gleld-vater-fertilizer data for corn grown under experisental conditions in colorado and Kansas, test statistics for the polynonial kansas, test stat istics for the polynowal for the nore coaplex itscherlich godels. (Auth.) AODEL TYPE: para netric

conHeHT: Enpirical function that could be used in a plant solute uptake aodel. The function has linited use for assessnent as it stands.

<93>

Hillel, D.. H. Talpaz, and H. Van Keulen. 1976. $A$ acroscopic-scale odel of water uptake by a nonuniform root systea and of water and salt ovenent in the soil profile. Soil sci. $121(4)=242-255$.

ARTRACT: dynanic nuaerical model, based on the transport equations for water and noninteracting solutes in porous aediun and 


\section{APPENDIX A \\ Agricultural Models (continued)}

<93> CONT.

written in IBH S/360 CSHP language, was designed to compute the wovement of vater and salts in a soil profile in the presence of an active root system. The inputs are: soil and root syster hydraulics, initial vater content and solute concentration, density and distribution of active roots in the soil pr of ile, and the cliaatically iaposed evapotranspiration rate vith its diuraal fluctuation. The output provides the patterns of soil moisture depletion nd of vater potential distribution in the soll and the vater potential in the plant as needed to waintain various transpiration rates, as well as the flow of vater and salt through the botton of the root zone. The wodel is illustrated for a nuber of coubinations of illustrated for a nuber of coubinations depths, initial soil vater contents, solute concentrations, and evaporativity levels. concentrations, and evaporativity levels. The pattera of soil asistut duplotion and function of soil, plant, and clinatic factors which can te wapped out systeratically and guantitatively by dynaic simulation, for a vide range of environaental conditions. Hovever, wuch experiaental research is yet required to obtain the appropriate input inforation for models of this kind and to inforation for models of this nODEL TYPE: mechanistic

CORMEN T: iseful in evaluation of technology im pacts on soil vater and cherical movement al though experimental input data are required as noted by the authors.

$\langle 94\rangle$

Hillel, D.. C.G. E. I. van Beek, and H. Talpaz. 1975. A aicroscopic-scale uodel of soil vater uptake and salt movement to plant roots. Soil Sci. 120: 385-399.

A BSTRACT: A numerical nodel, based on the tr ansport equations for vater and tr ansport equaticns for vater and noninteracting solutes and written in IBh
$5 / 36$ ? CSMP language. was designed to compute the radial movement of water and salts to the radial wovement of ater and salts to

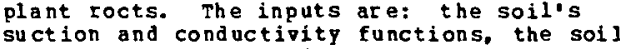
solution's content and concentration, root density and perweability, and the required uptake rate (whether constant or diurnally fluctuating). The output provides the time-dependent araudown of watric and osaotic potentials in the ianediate vicinity of the root the gradients and floy rates of rater and solutes in the soil, and the plant yater potentials needed to maintain different uptake rates. The model is illustrated for uptake rates. The model is illustrated for various rooting densities and various initial wa ter contents and salt concentrations. ef fect of increasing root density and permeablility is seen to be similar to reducing transpirational deaand. (Auth.) BODEL TYPE: mechanistic

c crant: vork is ton detai.led for assessment purposes.

$\langle 95\rangle$

Hillel, D.I. C.H. M. van Bavel, and H. Talpaz. 1975. Dynamic simulation of water storage in fallow soil as a fected by aulch of hpdrophobic ag̣gegates. Soil sci. Soc. Aa. proc. $39(5): 826-833$.

ABSTRACT: A pechanistic nuwerical model, based on fundawental physical principles and written in IBh $s / 360$ CSHP language, was designed to compute the dynamic balance of water in fallov soil through repeated cycles of infiltration and evaporation. The necessary inputs are: (i) hydraulic necessary inputs are: (i) hydraulic surface crust or mulch layer: (ii) duration and intensity characteristics of rainstoras or irrigations; and (iii) the potential evaporation rate as it varies diurnally and frou day to day. The output provides time-dependent rates and cunulative quantities of infiltration, runoff. surface detention, evaporation, internal drainage, and changes in water content of different layers and of the profile as thole.

computations carried out for a 4 -day

simulation (including tro rainstoras and four evaporation cycles) illustrate the use of the wodel for uniform, crusted, or mulched soil: and predict that the presence of a mulch of hydrophobic aggregates, several centioeters thick, can greatly increase the guantity of vater absorbed and retained in the profile. vater absorbed and retained in the p published experioental results and indicates a prowising appoach to soil mangeaent for
vater conservation in dryland and irrigated MODEL TYPE: mechanistic

COMHENT: Model could be used in infiltration analysis including the effects of crusting of soll surface.

$\langle 96\rangle$

Holford, I.C.R., and G.B.G. Hattingly. 1976. A nodel for the behaviour of labile phosphate todel for the behaviour of labil
in soll. plant soil $44: 219-229$.

ABSTRACT: The Languir tuo-surface adsorption equation is used to derive a phosphate adsorption characteristic, the maximui buffer capacity, which integrates the intensive and extensive components of adsorption and is independent of $P$ saturation. Changes in the intensities and guantities of labile $p$ and equilibrium buffer capacities resulting from fertilization of a group of 24 soils are shown to be related to the Langiuif high-energy adsorption paraneters and in particular the aariau buffer capacity. (Auth.)

MODEI TYPE: Mechan istic

cOMnEN: The function can be used in more comprehensive soil water-solute transport nodels.

〈97>

Holford, I.C.R., R.R.H. Redderburn, and G.E.s. mattingly. 1974. A Languuic two-surface equation as a model for phosphate adsorption by soils. J. Soil sci. 25:242-255.

ABSTRACT: For forty-one soils ( $\mathrm{pH}$ greater than 5.0) frow southern England and eastern Australia, the lang wiir equation vas an excellent model for describing p adsorption excellent mod el for describing padsorption was assumed that adsorption occurs on two types of surface of contrasting bonding energies. Por wost of these soils, which vere relatively undersaturated with $P$. nore than 90\% of the native adsorbed $p$ occurred on the high-energy surface. (Auth.)

MONRL TYPR: mechanistic

connent: The proposed function can be readily included in soil chemistry models. The
eapirical constants need to be evaluated for the soil of interest.

$\langle 98>$

Hugqins, L.P.. J.R. Burney, P.S. Kundu, and E.J. Monke. 1973. Simulation of the hydrology of ungaged vatersheds. Technical Report No. 38, Purdue Oniversity Hater Rescources Research Center, Iest Lafapette. IN.

ABSTRACT: The overall objective of the research project reported herein was the developaent of a watershed nodel capable of accuratel $y$ predicting hydrologic behavior of natural vatersheds for which data conceraing historical relationships between rainfall and 


\section{APPENDIX A \\ Agricultural Models (continued)}

(98) CONT.

ru noff events are unavailable, 1.e. ungaged catchents. This objective vas accomplished by a combination of laboratory studies related to overland flow and of the continued developnent of a vatershed nodel using $\infty$ mputer simulations of real stort events on gaged catchaents to deteraine a range of appropriate paraneter values for the rodel. The computer progran used to inpleaent the watershed odel together with saple data and its output is given. The vatershed odel developed in the research reported beloy uses a distributed an alysis approach rather than a distributed andysis approach rather than
the more coanonly enployed lumped spstea an alpsis. The odel involves the subdivision of a catchuent into a grid of sableleantal areas, the mathematical cbaracterization or modeliing of the various physical processes occurring vithin each eleaent and the nu nerical integration of the responses fron each vatershed elenent into a conprehensive description of not onl the discharge at the outlet. Lut of the conplete hydrologic lent of uhich the response of evory elesent of thich the catchient is conposed. The prinary al vantages of the distributed watershed nodel are its potential for increased accuracy due to its inherent capability to evaluate spatially $\nabla$ ariable factors ithin watershed and its comprehensive description of the total vatershed behavior. This latter aj vantage is of increasing inportance in providing a aeans of evaluating, in a very broad context, the potential environaental effects of alternate prograes for resource de velopment. The privary disadvantage of distributed odels is the greatly increase computational offore required to utilized thea. Ilowever, large cowputers have largely removed the economic liaitations associated with this approach, at least swall wa tersheds. (Auth.)

MODEL TYPE: paranetric

Conk EN: Potent ially very useful in assessuent since it can allow evaluation of situations with liaited data sources. Applications to agricultural vatersheds are included.

$\langle 99\rangle$

Incropera, P.P. 1975. Leaf photosynthesis: The influence $c f$ envircnaental variables. Environ. Qual. 4:400-447.

ABSTRACr: oodel is presented for the effects of light intensity and abient temperature. celative huldity, and carbon dioride concentration on ieaf photosynthesis. The oodel treats diffusion and chelical processes ocurring vithin the leaf, as vell as the transfer of wass a nd energy between the leat and its environnent. Calculations have been perforwed for zeA haYs L. (maize) which suggest the influence of environeental changes. Al though leaf energy exchange processes act to moderate the effect of changes in the atmospheric tenperature. a severe cooling trend ay cause as nuch as $20 x$ reduction in photosynthesis. onder nost reduction in photospnthesis. onder nost conditions, the rate of photospnthesis is
further dianished by a reduction in relative huaidity. In contrast. a $20 x$ increase in the at mospheric co (2) concentration, which if projected for the pear 2000. Vili increase photosynthesis by approxiately 15\%. The calculations also suggest optiaue ablent conditions for controlled grouth

environuents, such as a greenhouse. In addition tc a saturating light intensity of ap proxinatel 700 \%a**2. these conditions include of a proxinately $30 \mathrm{C}$ and $90 \mathrm{x}$, respectively. of approxinately $30 \mathrm{C}$ and $90 \mathrm{x}$, cespectipely.
and $\mathrm{a}$ co (2) concentration of approxiately and $a C O(2)$ concent MODEL. TYPE: Dechanistic

c chaten: Physiological research oodel uith too
Duch detall for assessent purposes.

$\langle 100\rangle$

Jackson. J.E., and J.H. Palner. 1972 Interception of light by wodel hedgerov orchards in relation to latitude, tiae of year and hedger ow configuration and orientation. J. Appl. Bcol. 9:341-357.

ABSTRACT: Light interception by codel hedgerov orchards and light distribution over thelr surfaces vere inpestiqated using a conputer furfaces uere inpestigated using a conp graphical technique to study the distribution

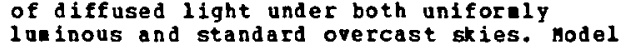
lueinous and standard overcast skies. trlangular, and rectangular section, eacb with three different ratios of hedgerow height to alleyvay width vere considered at latitudes 51.3 deg.. 45 deg. and 34 deg. When only half the ground area is covered with hedgerow and the hedgerow helght is equal to the alleyvag width, over $80 x$ of available light can be intercepted. As the rat io of hedge height to alley widt is increased, direct light interception is increased in such sualler proportion. Light increased in such sualler proportion. Light of the hedge sides to the horizontal and at lover latitudes especially for east-vest oriented hedgerous. While there is little change in percentage interception by north-south oriented hedges as the season progresses, there is a marked seasonal pattern of interception by east-west hedges and this varies vith latitudes. As bedge height is increased so is the proportion of poorly illuainated ourface and as the anglo to the horizontal is decreased the evenness to the horizontal is decreased the even increased. Illumination of the south faces of increased. I l luwi nation of the south distributed, the uniforaity being greater for distributed, the uniforaity being greater for sides and at lou latitudes than at high lat itudes, but it varies considerably with tine of gear for sone hedgeroy confiqurations. Interceptlon and distribution of diffuse light is rat.her sioliar to that of direct light for north-south hedgerous. The effects of latitude on light interception and distribuilion over hedgerow systens of differing proportions appear large enough to influence significantly the value of influence significantly the value of different systens of planting. This vill orchards. (Auth.)

MODEL TYPE: eechanistic

ConMENT: hodel could be used to evaluate shading effects of structures on agricultural systens.

$\langle 101\rangle$

Jahnke, L.S., and D.B. Lavrence. 1965. Influence of photospnthetic $c$ rovn structure on potential productivity of vegetation, based priparily on athenatical models. based priacily on
Bcolog $46: 319-326$.

ABSTRNCT: Productiolty studies have shovn that plants with aaced rertical extension of photosynthetic crown can be nore productive per unit area of land or vater occupled than plants wose photosynthetic surface is spread in a thin horizontal sheet on the earth's surface if environental factore are not othervise liniting. Beonetric nodels including a flat disc and cones of several heights but constant base radius shov that heightening cones intercept progressively aore light. Amount of chlorophyll displayed per unit area of earth's surface can also per unit area of earth's surface can also increase greatly ith vertical extension aerial crown. These observations cuggest chlorophyll content of the photosynthetic 


\section{APPENDIX A Agricultural Models (continued)}

<101> CONT.

portion of the vegetation per unit area of earth's surface, and light intensity incident on surfaces at right angles to sun's rays should be measured and described as basic data in priary froductivity studies. (Auth.) MODEL TYPE: Dechanistic

C CAHENT: Probably not usefal since ot her wore comprehensive models are available.

$\langle 102\rangle$

Jakobsen. B.P. 1973. Interrelations of soll physical characteristics. Acta kgic. Scand. $23: 165-172$

ABSTRACT: Dater retention, hydraulic conductioity, and oxygen diffusion at different soll bulk densities, and soil compactability at different ater contents of - loa soll were measured. Thermal characteristics vere calculated at different bulk densities and vater contents. Ha theatical expressions for the relations and interrelations were found for the use in construction of aodels for plant grovth, and for an a teept to optialze the soil structure for plant grouth under given clinatical conditions. The system ay be applied to ot her soils not too loy in clay content and of fers possibilities of surveying a nd handing the probleas of changes in soil structure. Derivates of the interrelations between soll factors nay yield good estimates of changes in soll conditions caused by a change in one factor. (Auth.)

HODEL TYPQ: parasetric

c cHA EN - : Approach provides a means of estiating soil properties usually required in detalled soil properties usually required in detailed extending the range of modeling applications where linited soll data are available.

$\langle 103\rangle$

Janssen, J.G.H. 1974. Simulation of gernination of vinter annuals in relation to aicroclima te and nicrodistribution. Decologia (Ber 1.) 14:197-228.

ABSTRACT: Aigulation progras on the ge rmination of vinter annuls is vitted in such a way that the influence of changing en environaental conditions on gerdina characteristies such as the time of and the distribution function of gersination is described as vell as possible in accordance vith experimental data. The changing environeental conditions are si mulated by a progran that describes the changes of the aicrocl latological characteristics, tencerature and woisture content of the soil, during a nubber of days depending on local conditions and acrode pending on local conditions and aco meteorological data. The sianlated the two differences in geraination betveen the two Winter annuals VERON ICA ARVENSIS L. and
WOSOTIS RAMOSISSIHA Rochel Er Schult. at different sites are discussed in relation to differences in their icrodistribution. A vay is indicated to characterize in ecoloqical studies the nicrocliantlogical situation of a site in the field. (Auth. MONEL TTPE: mechanistic

cona $T:$ The representation of teaperature and water efferts on geraination could be used in assessment studies.

$\langle 104\rangle$

Jones, J.R., R.P. Coluick, and E. D. Threadgill. 972 . A simulated enpironeenta 1 podel of temperature, evaporation, rainfall and soil moisture. Transactions of the $A S A$ $15(2): 366-372$

ABSIRACT: Weather is a prisarp forcing function for decisions conceraing crop production.
Plant models bave been de reloped to siuulate plant production based upon the veather that is inposed upon the "computer plant". For studying a complete crop production systea. it is desirable to have an environgental adel to provide sinulated fleld conditions for a particular location. in which the "conputer plant" is to be grovn. This study was designed to develop an environment nodel for crop production or other hiolngiral systels to propide inputs of daily rainfall. teaperature, evaporation, and soil moisture variations with depth. Review of the variations with depth. Review of the conducted to describe tenperature and conducted to describe tenperature and $r$ ainfall distributions at other locations
alt hough Do sililar work was found for

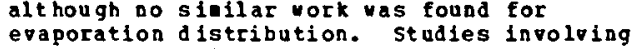
unsaturated soll moisture transfer were found but wost of these studies vere confined to laboratory conditions. The systenatic conbination of results from the previous studies vith results from this research provided a model for simulating these selected environental parameters under selected environmental parameters under natural conditions. Punctional relationships These relationships indicated the

These relationships indicated the ioterdependence anong the varlables of
tewperature. rainfali, evaporation, and soil golsture content. Actual veather records for state college. Hss. vere used to develop nodels for the veatber siaulation. In general, rainfall and tive in the year vere iaportant in simulating veather variables. It was found that dally rainfall amounts did not follow any seasonal trend for $s$ tate college, but rainfall probabilities did College, but rainfall probabilities did depend upon the time in year. The nont

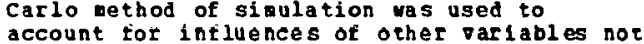
account for influences of other variables relationships. The veather nodel was $r$ un on the computer and 10 years of silulated data vere shoun to cowpare very closely uith observed data for state college. The soll -oisture model produced results that fell within 10 percent of the observed data for at least 43 days. It was concluded that $t$ he codels developed in this paper can be used to provide basic environmental variables for use provide basic environwental variables for us in crop prodaction siaulations for studying cethods of simulation developed in this paper show pronise for studing and projecting environnental factors. (Auth.) MODEL TYPE: stochast ic

conHENT: oseful rainfall and tenperature siaulator developed for nississippi conditions. valuable for assessment.

$\langle 105\rangle$

Jurinak, J.J., S.B. Lai and J.J. Hassett. 1973. Cat ion transport in soils and factors affecting soil carbonate solubility. affecting soil carbonate solubility.
EPA-R2-73-235. O.S. Environental Protection EPA-R2-73-235, S. Kerr Environmental Research Agency. Robert S. Kerr Envi romental Resea
Laboratory. P.O. Box 1198, Ada, OK 74820 .

ABSTRACT: $A$ predictive oodel of cation transport in soils was dereloped and tested. This aodel involved the definition of the cation exchange process in soil coluans during the lscible displacenent of cation solutions. ass balance equation was formulated uhich ass balance equation was foraulated included a general nonlinear exchange
function. The solution of the equation as function. The solution of the equation was accomplished by nunerical othods. The met through an exchanger using five different types of exchange functions. The nodel vas further tested by conducting soil colum studies vhere both ho sovalent and heterovalent exchange occurred. The agreenent between predicted cation transport in soils and experinental data was good. 


\section{APPENDIX A \\ Agricultural Models (continued)}

$\langle 105\rangle \operatorname{con} \mathrm{T}$.

Laboratory studies vere also conducted, using the carbonate saturoseter. to a ssess the ef fect of $\mathrm{Mg}+2$ ion on the solubility of ma reous materials. Carbonate solubility in the presence of $\mathrm{Hg}+2$ ion was found to vary it th the surface area of the solid phase. the with the surface area of the solid phase, the degree of saturation of the vater vith degree of saturation of the vater vith respect to a given carbonate ineral. when $g+2$ was present, in waters which were unsaturated with respect to calcite. carbonate aaterial wich contained a gnesiua as a constituent ion. e.g.. dolonite. decreased solubility as Mq+2 concentration increased in waters which were near saturation with respect to colonite. (Nuth.) HODEL TYPE: Mechanistic

COMH T: Hodel applies to saturated conditions and could be used for assessment of flooded soils and groundvater ilpacts of technology.

$\langle 106\rangle$

Kabel, R.L.. R.A. O'dell, M. Taheri, a nd D.u. Da vis. 1976. A preliuinary odel of gaseous pollutant uptake by regetation. CAES publication No. 455-76, Center for $A$ is Environgent studies. The Pennsyluania $s$ tate Oniversity, Unifersity PaIk, PA 16802

ABST RACT: The objective of this research is to In vestiqate the various mechanisms and factors wich control gas uptake by vegetation and to develop quantitative rethods for predicting the uptake rate. sulfur dioxide (So(2)) is used as an exaple pollutant of interest. Pirst. the three resistances to uptake - aerodynamic. stomatal, and wesophylific - are described and then characterized in terms of controlling then characterized in teris of controlling has been used by plant physiologists since Ga astra (1959) or earlier. Pactors uhich control the individual leaf aerody natic resistance, $I(a)$, are vind speed, leaf size and geometry, and gas piscosity and diffusivity. The stonatal resistance, If is a function of the stonatal opening. Which in turn is affected by vater deficit, co(2) concentration, and light intensity. The mophyllic resi stance, $r$ (a), is related to ons solukility in vater. oas-ligujd ons snluktity in whter. gas-ligujd leat hydrodynamics and chesical reactions. leat hydrodynarics and chemical reactions. The three resistances. which are based on the at mospheric gas concentration difference to yield the uptake rate per unit leaf area. Therefore, if the leaf characteristics and environmental paraeters wich control the resistances - wind speed, atmospheric molsture, teaperature, and light intensity are known, the gas uptake rate by the leaf can be estinated. As an initial test of the model. estimates of gas uptake hy vegetation model. estimates of gas uptake hy vegetation the uptake rate by loaves is known. the the uptake rate by loaves is known, the over vast vegetated tracts nay be calculated. Ther the iupact of vegetation, considerea thon. the idpact of vegetation, conside red ca $n$ be assessed. (Auth.)

MODEI TYDE: nechanistic

COHBN $T$ : os $\in$ ful model for assessnent purposes.

$\langle 107\rangle$

Kallis, A., and H, Tooning. 1974. Estimation of the influence of leaf photosynthet ic parameters, specific leaf weight and grovth functions cf yiela. photosynthetica functions cf

ABSTRACT: Changes in the grovth rate and in the CI op grain gield due to the variations in parameters of photospnthetic and respiratory functions, and the specific leaf veight and grovth functions of different organs of plants at various regines vere studied under the assumption that other environmental conditions vere not liniting. The systea of grovtb equations derived by Boss (1967) and the wathenatical aodel of plant productivity wich took into account adaptation to irradiance were used in crop growth and yield analyses. As an exanple yield calculations were ade vith grouth functions of barley (HORDE OH VULGARE $L$. $\approx \nabla$. DOmen) as basic par aneters. According to these calculations an increase in grain yield may be expected only at optinua combinations of the photosynthetic activity. Iespiratory econony. specific leaf velght of leaves and grouth functions, provialing an optiaun leaf arte index of crops and their high net photosynthetic rate as a uhole. (Auen.) HODEL TYPE: mechanistic

COnnEMT: Hodel contains physiological detail and is applicable to research on photosynthesis.

$\langle 100\rangle$

Ratznelson. J. 1977. Phosphorus in the soil-plant-anial ecosystea. Decologia (Berl.) 26:325-334.

ABSTRACT: A compartmental nodel of phosphorus in soll-plant-aninal ecosystea is described. It consists of 19 coapartments, five in soll. six in plant, threc in aboveground fauna and three in soil organisas and aicroorganisis. compon anounts and rates of turnover in each of these compartments is presented. Though the total anount of $P$ in the ecosystel is large, only a very suall part of it is being cycied. and presented data show that renoval cycled, and presented data shor that renoval is very slight. Most of the avaflable phosphorus which is absorbed by plant roots is gradually fixed in fores of long-range unavallablitit. both by plants and by anials. This process of biological fixation is counterbalanced ainly by the activity of soil icroorganisws. Quantities of input-output of $P$ in intensive pastoral ecosysteas are also presented, and sone agrononical and ecological inplications are considered. The anipulation of soil icroorganisms and change touards ore desirabie $P$ releasing strains or specles ay decrease need of fertilization. lover the risk of eutrophication and enhence productioity of such ecosysters. Such nanipulat lons, hovever, can be achieved only after appropriate research. (Auth.)

NODEL TTPE: paranetric

Congenr: Hodel is tuned to data fron literature and is used to investigate principles in ecosystex analysis. The nethod could be adapted to assessient purposes.

$\langle 109\rangle$

Rercher, J.R. 1977. GROA1: A crop grouth nodel for assessing impacts of gaseous pollutants for assessing iapacts of gaseous pollutants lavrence hivertore labotatory, California.

ABS'RACI: A prelininaig modol of photusythesle and grouth of field crops was developed to assess the effects of gaseous pollutants. particularly airborne sulfur conpounds. resulting fron energy production froa geothermal resources. The model simulates photosynthes1s as a function of such variables as irratiance, co(2) diffusion resistances, and internal biocherical processes. The mode 1 allocates the products of photosynthesis to structural (leaf, ster. the plant. The sialations encoapass the entire growing season from geraination to entire growing season fon gerain conceptualiy and atheraticalig and provide 


\section{APPENDIX A \\ Agricultural Models (continued)}

$\langle 109\rangle \operatorname{con} T$

examples of nodel output for various levels of pollutant stress. 1so. ve outline future developwents that would inprove this prelinirary nodel and discuss its ap plications.

HODEL TYPB: mechanistic

COHA $\mathrm{T}$ : Verp useful lodel developaent for as sessolnt of aif pollutant effects on crops ith exphasis on the photosinthesis process.

$\langle 110\rangle$

Kercher, J.R., and i.H. Shugart. 1975. Trophic structure, effective trophic position, and connectivity in food vebs. Aa. Nat. 109:191-205.

ABSTRACT: A nev measure of distance fron the food source to any meaber of a food veb is introduced. This neasure is refercen to as effective trophic position. Iffective trophic fosition is defined as function of energy ingested per unlt tiae by a population and the production of the autotrophs necessary to aantain that population. Trophic position thus defined is a generalization of the trophic-level concept. An algorith is developed to construet food we with ecological constraints to examing statistical distributions of the standing crops and trophic positions in food vebs. Ecological constraints a re laposed on food chain length and on the range of transfer efficlencles in food vebs. Honte carlo technigue as used to generate adel food vebs vith an arbitrary nuaber of internal connections. The nuaber of connections ranges frow the aininum possible (corresponding to siaple fcod chains) to the axiaum possible (extrealy connocted food wabs). The relationship bet ween bionass and trophic position distributions of food vebs vere exanined. The monents of these distributions are deterained in part by the connectivity of food rebs, and a possible application is the estination of connectirity and trophic position distributions by easuring the biomass distribotions. Regressions vere found relating food-web connectivity to the found relating food-web connectioity to the distributions al ong the effective trophic distributions al ong the effective trophic indicate that food web standing crops shnuld he log pearson Type I distributed. A siailar result is found in field weasares of food we bs.

MODE L TYPQ: stochastic

Conla T: Theoretiral annlysis of food veb nodel characteristics. Not directly applicable to technology assessaent.

(111)

Kline, J.R. 1973. Hathenatical sinulation of soil-plant relationships and soil genesis. Soil SC1. 115:240-249.

A BSTRACT: Matheatical siaulation is a technique draun frow the engineering disciplines whic shows provise in dealing with sone problems in soll-flant relationships and soil ge nesis. It s potential usefulness is derived from the fact that it offers the possibility of waing predictions about soll-piant spsteas in situations which ake it uncealistic to obtali data by drect aeasuieaent. The preaictions are based on sinulation of spsten preaictions are based on sinulation extrapolation. In this paper three exaples are presented in which fairly realistic silulaticns of - the effects of radioactive fallout and fertilization in soil-plant systeas have been ade. Pinally, a proposal is aade for an initial approach to the simulation of some aspects of soil foration. If adequate siaulation odels can be devised for soll foratiou ux systea peiturbations, it opens the possiblitip for conputer "ganing" exercises. Such exercises aay ake it possible to exanine the effects of independent variables, such as clisate and vegetation, on soll genesis in an experinental setting or to optinize eanagenent strategies in the use of fertilizers and pesticides in agriculture. (Ruth.)

OOPE TYPQ: paranetric

COBAENT: Paper c ontains exanples of systeas analysis models relevant to assessaent purposes.

〈112>

Rraeger Rovey, C.E. 1975. Nuwerical nodel of flov in a strean-aguifer systen. Aydrology papers No. 74, colorado state oniversity. Pt.

Collins, Co,
A BSTRACT: A three-dinensional, finite difference odel vas developed for sioulating steady and unsteady, saturated and unsaturated flov in a strea aquifer syster. The basis of the wodel is the finite difference for of Richard's equation for unsaturated and saturated subsurface flov. Effects of streasflov on groundwater morenent are treated by applying the appropriate boundary conditions to Bichard's equation.

contributions of grounduater to river flov are quantified by including seepage rates in the colputation of river discharge. The three-divensicnal model vas developed for use in this study to interact ith two-diaensional odel segents, which vere two-diaens lonal odel segents, which vere on its upstrean and dounstream ends. The on its upstream and downstrea ends. The dat a for the study area. Which consisted of a 40 aile reach. of the Arkansas valley of Southeastern colorado. Conputed estinates of river discharge at each end of the study area and water table elevations throughout the region agreed reasonably vell with observed data. An analysis of the sensitivity of results produced by the oodel to variation in the values of several input paraseters vas the values of several input paraseters
included as part of the stady. (Auth.) HODEL TIPE: echanistic

ConngNT: Detalled vater flow nodel uith potential use in assessment although detailed site data are required for inpots.

$\langle 113\rangle$

tarsen, R.I.. and W.H. Heck. 1976. An air quality data analysis spste for intercelating effects, standards, and noeded source reductions: Part 3. Vegetation infury. J. Air Pollution Control Assoc. 26: $325-333$.

ABSTRACT: Acute leaf injury data are analyzed for 19 plant species exposed to ozone or sulfur dioxide. The data can be depicted by a nev leaf injury wathenatical nodel vith two character lstics: (1) constant percentage of leaf surface is injured by an air pollutant concentration that is inversely proportional to exposure duration $r$ aised to an exponent: (2) for a given exposure duration, the percent leaf injury as a function of pollutant concentration tends to fit a lognorsal frequency distribution. Leaf injury as a function of laboratory exposure duration is oodeled and conpared with anblent air pollutant concentration easureants for air pollutant concentration easurenents for various a veraging ties to deteraine
exposure durations are probably nost exposure durations are probably most inportant for setting anbient air quality infurp. The 8 hour average appears to be most luportant for wost of the plants investigated for nost sites, $1 \mathrm{hr}$ concentrations are ilportant for nost plants at a feu olteo, and 3 he $80(2)$ concontratlons 


\section{APPENDIX A \\ Agricultural Models (continued)}

〈113> ConT.

are important for sone plants, especially those exposed to 1solated pcint sources of the pollutant. The 1, 3, a nd 8 hr threshold injury concentrations are listed for each of the 19 plant species studied. To prevent or reduce acute leaf infury. fixed.

nonoverlapping abient air quality

measurements and standards are recomended

for averaging tiaes of 1, 3. and 8 hr.

(it uth.)

MODEL TYPE: paranetric

CAMEN T: oseful expirical data source a nd representative function that $c a n$ be used to predict visible plant response to air pollution.

$\langle 114\rangle$

Lavore 1, J. 1976. Natrix analysis of the oxygen evolving systed of photosynthesis. $J$. Theor. Bi ol. 57:171-185.

ABSTRACT: A linear four-step aodel is currentl aj opted to interpret the kinetic behaviour of the oxygen evolving systco of higher plants" the oxygen evolving systco of higher plants
photosynthesis. Applying at tix analysis to photosynthesis. Applping matrix analy this model allows one to derive three spmetrical functions of the transition they constitute in general tho only information concerning the nodel which can be extracted frod experinental data. The analysis is applied to a series of published data. Ne proferties of the oxygen evolving sy stex are thus disclosed. (Auth.)

MODEL TYPE: wechanistic

C CMMEN T: Basic plant physiological model with no ap plicaticn in assessoent.

$\langle 115\rangle$

ettan. B. 1979. Deteraination of the theraal diffusivity in the upper layers of a natural gr ound ccrer. Soil sef. 112:173-177.

ABSTRACT: It has been shovn that the tenperature va riation in an inhomogeneous aediua can ba represented quite vell by assuding that the vertical heat flux divergence which produces the local teaperature change is conposed of tuc terms: a classical ter incorporating the curvature of the tenperature profile, and a gradient tera (here defined) incorporating a gradient tera (here defined incorpor conductioity. Although the differential equation of tenperature as a function of tiae eguation of terperature as a function of tiae ma not be sol ved analytically, the tenpora
variation may be synthesized by nunerical

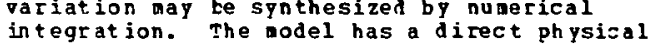
in terpretation and does not require the introfuction of matheoatical artifices such as a diurnally varying theral diffusivity or a negative thermal diffusivity. The model furthermore accurately reproduces the a ibient thermal frocesses, and the derived results are not antiguous in the sense of parameters derived separately frow the aplitude decrease and the phase lag of an applied decrease and the phase lag of an ap DODEL TPPQ: techanistic

COHH $\mathrm{T}$ : The effects of waste heat on soil thermal froperties could be evaluated vith this wodel.

$\langle 116\rangle$

Lind st rom, M.J.. R.I. papendick, and F.E. Roehler. 1976. A model to predict vintor wheat emergence as affected by soil temperature. water potential, and depth of planting. Agron. J. 68 (1): $137-141$.

ABSTRACT: Establishnent of adequate stands of winter wheat (TR ITICOH AESTIVIM L.) in winter wheat (TRITICOH AESTIVIn L.) in northwest osA is often hampered by loy soil tomperature or moisture, or by deep planting to reach oolsture sufficient for ea
Becauge of the vide variability and
Inter active effects anong these factors, it is often difficult to predict the rate and extent of emergence of field plantings. A uodel was devised to predict esergence tine of 'McCall' and 'Nuga ines' vinter yheat as a function of soil teaperature between 5 and 25 c. vater potential doun to -10 bars, and planting depth. Predictions vere reasonably good when conpared with field aeasurenents, particularly at high vater potentials and particularly at bigh water potentials an ith shallow planting. In general, the energence rate progressively decreased with teaperature from $25 \mathrm{c}$, or with increase in planting depth. The lower liait or atnimut vater potential for eaergence increased vith increasing teaperature. Buth whats

responded sibilarly to teaperature decreases; havever, the apergence rate of each varioty responded differently to change in vater potential. Differences in varietal response to water potential can possibly be characterized in teros of tuo paraneters in the function describing the water potential effect on energence. (Auth.) paranetric

ConkERT: hodel could be used to evaluat temperature effects on what energence in northuestern OSA.

〈117>

Lungley, D.R. 1973. The grovth of root systems - A nuverical conputer sinulation model. Plant Soil $38(1): 145-159$.

ABSTRACT: A simulation model of the grouth of the plant root systen is described. Pirstly, the numbers and lengths of the laterals the nuabers and lengths of the laterals speciriea $r$ ates of elongation and oratichifig. secondly. the vertical distribution of fllawent length is obtained, after specifying the rate of initiation of axes at the crown of the plant and the orientation of successive, short straight segments representing the curved roots. Diagraws of the network can be produced using the graph-plotting facility of coaputer, and other properties such as the distribution of length of filaaent of given age and the distribution of a pice $s$ can be conputed. The wodel has sufficient flexibility to incorporate inforation on the temporal incorporate inforation on the temporal of grouth found under non-unifor conditions. The atility of the oodel in agronodic studies is illustrated by using it to calculate the effects of fertilizer treataents on the root distribution, given certain grouth responses expressed in tarns of rates of elongation and branching. The exanples considered pertain to (a) the enrichment of a layer in the soil with a fertilizer supplying a scarce nutrient and (b) a deferred applitication of a fertilizer supplying a scarce nutrient. (Auth.) MODEL TYPE: parametric

COABET: Could be adapted to evaluate pollutant effects on root de velopient.

(118)

Lupton, P.G.H. 1972. Purther experiments on photosynthesis and translocation in wheat. Ant. Appl. Biol. 71:69-79.

ABSTACT: Aodel is developed relating photosynthesis taking place in successive layers of the canopy of a wheat crop to the intensity of the $x$ adiation incldent on the crop, the elevation of the sun, and to the angle to the horizontal and photosynthetic angle to the horizontal and photosynthetic validity of the model is tested by cooparing the rate of photosynthesis. pattern of translocation and solid geonetry of a seai-dran $f$ weat (TI $365 a / 25$ ) vith those of a 


\section{APPENDIX A \\ Agricultural Models (continued)}

$\langle 118\rangle \cos T$.

va riet of conventional height

(Cappelle-Desprez). The aodel gives

realistic estinates of crop yield and

indicates that the greater pield of the

seli-d varf selection is caused by faster

photosynthesis, despite less photosynthetic surfaces of ears and leares. It a lso

indicates that selection for erect leaves aap

lead to further increases in yield. (Auth.)

YODEL TYPE: wechanistic

COMn T: Basic plant physiological model with no

di rect application in assessaent studies.

$\langle 199\rangle$

Luxmore, R.J., C.L. Begorich, and R.R. Dixon.

1978. Hcdelling solute uptake and

incorporation in to veget ation and litter. Ecol. Hodell ing 5: 137-171.

ASTRRCT: The concepts ant aigartithas of the Ba lduin. Hye and Tinker nodel describing solute novenent froa bulk soil solution into roots (DIPAAS) and a aodel of solute dynanics and accurulation in plant tissues and litter (DRYADS) are presented. Pollar uptake of solutes and gases are included in the DRYADS code. These aodels form coaponents in a coupled systea of nodels having hourly resoluticn of carbon. vater, and solute resoluticn of carbon, vater, and sold

dy naalcs in terrestrial ecosystens. monthly, and annual results illustrate the wonthly, and annual results illustrate the utility cf the models. The oRYADS oodol
sensitive to both leaf solute cond uctivity and root sol ute conductivity parameters suggest the Iuportance of careful

experimental deternination of these plant properties. The tissues of solute entry (leaves, toots) initially accuaula te solutes in a fired forn in preference to the nore remote tissues (steas, fruits). Hodel application results show that coot sapwood is the first ajor site of trace contaninat accualation frow soil-borne pollutants. The algorithos describing solute bovenent a iong algorithos describing solute movesent a long concentration gradient in phloe and as aass flow in the xylez transpiration streas resu
in high mobility of solutes in vegetation. in high mobility of solutes in regetation. The simulated diurnal pattern of root solute we re taken up during the daplight hours. The sioulations further shoved that contaminants had the greatest effect on the litter syster. Toxic ef fects of contanina nts on decouposition resulted in lower

mineralization losses and accunulation of contaminant in litter vith continuing depositicn.

gODEl TrPE: Gecantstio

C CMMEN T: Oseful for sloulation of particulate and gaseous pollutant transport and effects in soll-flant spstens. Exaple of heavy aetal and sulfur dioxide uptake given.

$\langle 120\rangle$

Luxmoore, R.J., J.L. Stolzy, and J.T. Holdean. 1976. Scae sensitivity analyses of an hourly soil-plant-vater relations aodel. OR NL T:M - - 343 , Oak R1 dge Nat ional Lab.. TR.

ABSTRACT: Nineteen paraseters representing la ndscape, plant, and soil characteristics plant water relaticns, daily fluxes and

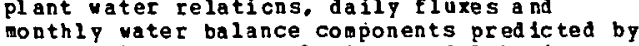
a soil-plant-water relations model having. hourly resolution. A standard set of paraneters yas chosen to represent a hardrood forest on ridge top soil in the oak Ridge, Tenessee area during a representative suaser month (July). Each paraneter was varled through a range vith all other parame ters held at the standard value. The results of the stud shoved that the iodel vas sensitive to nine plant parameters in noon, daily and aonthly results. The ten other paraneters. had partial or no influence on the simulations. Tro leaf characteristics and two 1 andscape properties cause the podel to be sensitive in idaday values but less bensitive in monthly results due to the negative feed back aspects of the model. Pire paraneters had al uost no influence on the model results in the case exanined. The canopy intercepti on paraneter had ilmost no influence on the oodel results on sunn y days. but was a signiflcant conponent of the wonthly water balance. The study highlighted the inportance of the root and sten resistances to water flow in influencing plant water status and the conthly water balance. This study has prorided an assessaent of the model stability to wide ass essaes of paraueter values and suggests the ranges of paraceter values and suggests the aodel's atility in a range of applications. crops on most soils and in diverse landscape situatlons. Purther, the consequences of using parageters vith high uncertainty in an application ay be partially evaluated from these sensitivity tests. (nuth.)

MODEL TYPE: wechanistic

COAnENT: Results fron study could be used in assessuent to evaluate possible effects of environmental changes on plant vater relationships.

〈121>

Luxaoore, R.J., I.T. Stolzy, and J. Letey. 1970. orygen diffusion in the soll-plant systed. I. Aodel. Agron. J. 62:317-322.

ABSTric T: $A$ codel for steady state, isothernal oxygen diffusion into a cyliadrical root surrounded by a vater fil of unifora thickness is proposed. Equations are developed which account for longitudinal oxygen flux through the interculialar $g$ as spaces, radial flux through the vater fild. and a fespiratory oxygen sink which is defined as a function of oxygen concentration. A method of coaputer analysis is outlined whereby the lay of continuity is is outlined whereby the la of continuity is root. such that the amount of oxygen diffusing into a section is equated vith the oxygen diffusing out $p 1$ us the respiratory consusption. The solution for the nodel defines a serles of oxygen concentrations along the root length. Pron these data the anount of oxygen consused in respiration which diffuses into a top of the root (plant aeration) and the anount diffusing radially fron the soil (soll aeration) nay be calculales, and effecis of soll and plant characteristics exanined. (Auth.)

MONEI TYPE: echanistic

COAKENT: Ang technology 1 Ipact on plant or environaental properties used in the model could be evaluated. Model is malniy concerned with physiological research.

<122〉

May, P. P., A.R. Till, and h.J. Cuawing. 1972. systeus analysis of 35 Sulphur kinetics in pastures grazed by sheep. J. Appl. Rcol. 9:25-49.

A BSTRACT: A nathenatical odel to represent the sulphur cycle in a grazed pasture was
programued on to an analog computer to programed on to an analog computer to experinent in which observations vere a ade on the incorporation of radioactivity into vool folloving a single application of [35s]gypsum to pasture. The behaviour of parts of the system not directly aeasurable and its responses to possible eapirical anipulations vere studied on the conputer to suggest exper laental tests of the model. The results of the study show that: (1) The observed 


\section{APPENDIX A \\ Agricultural Models (continued)}

〈122> CONT.

transient behaviour of the specific activity of wool is consistent with a closed-syste recgcling process involving c. 608 of the total sulphur in the systea. (2) Jp to $90 \%$ of the cycling sulphur aag be held in organic residues in foras not directly a valable to plants. (3) The rate of release of organic sulphur fron these residues in for ms suitable for plant uptake is a major deterainant of the plant uptake is a major deterinant the sulphur supply to plant and aniaal comartaents of the systen. (4) The
productive potential of the system is in productive potential of the system is in
general deterained by the rate of sulphur transport betveen coaparteents rather than the a wount present in any compartment at any ti we. (Auth.)

MODEL TYB, paramotris

C CHAENT: very useful aodel for assessment of chemical transfer in plant-animal systeas.

$\langle 123\rangle$

cCullough, E.C.. and H.P. Porter. 1971. computing clear dap solar radiation spectra for the terrestrial ocological environment. EE 0109452 ! $1008-1015$.

AESTRACT: clear sky (cloud-free) horizontal pl ane terrestrial solar radlation spectral fluxes can be conputed for any time of day and pear, geographic location (latitude and long itude), and elevation upon inputting the optical froperties of the ataosphere and reflecting properties of the underlying surface. Consideration is given to the surface Consideration is given to the
problew of diffuse terrestrial radiation problem of diffuse terrestrial radiation spectra fcr non-sea level elevations and Where the terrestrial at osphere ca regarded as being purely a Rayleigh
atmosphere. Couputation of terrestrial at mosphere. Couputation of terrestrial
spectra for "large" zenith angles (2 greater than or equal to 72 deg.) is considered along with a discussion of irradiation patterns peculiar. to polar zones (i.e.. long days and nights). Selected results froa the integration of the se concepts into a conputer progran include the cosputation of total diffuse-to-direct flux ratios for radiation frouse-to-direct fux ratios for radia from a pleigh atrosphere at an solar trpical aen ground al bedos. Coaparisons of in tegrated energy predictions with measurenents in the literature agree ravoraoly. (auth.)

MODEL TYPE: nechanistic

COAHEN: Iseful in evaluation of spectral changes in frradiaton hich could be induced by technology in pacts on the optical properties of the atmosphere.

Yiller, E.R. and J.H. Horman. 1971. A sunfleck theory fcr plant canopies, I. Lengths of sunlit segwents along a transect. Agron. $J$. $63(1): 735-738$.

ABSTRACT: The size distribution of sunflecks under a plant canopy can be represented by the length distribution of sunlit seqnents al ong a straight-line transect draun under the canopy. A matheatical connection is deduced tetveen this sunlit-length distribution and the probability, as a function of length. that a short line placed function of length, that a short line placed randomly ander the canopy vill be every in sunlight. In turn, this probability distribution is deduced for randonly-p

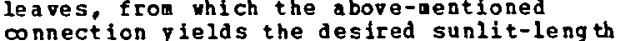
$\infty$ nnection yields the desired sunlit-leng
distribution. In subsequent papers this basic result will be used to predict the effect of cenumbra - fuzzy shador edges ca used by the finite angular size of the sun - upon the light intensity distributions vithin or beneath canopies, as a function of le af size, shape, height, density, and orientation. (Auth.)

HODEL TYPE: vechanistic

COABET: Theoretical analysis that could have some assessment applications. Hoverer, in teras of photcsynthesis prediction. the penunbra effects do not contribute significantly.

$\langle 125>$

Miller. E.E., and J.A. Horaan. 1971. A sunfleck theory for plant canopies. II. Penunbra effect: Intensity distributions along sunfleck segaents. Agron. J. 63: 739-743.

ABSTRACT: The finite $(1 / 2$ deg.) angular dianeter of the sun causes the fuzziness of the shadow cast onto the ground by a leaf edge to inrroace in propnrtinn +n increase in helght of the leaf. Dhen a straight-line sunfleck segment is terminated by leaf edge that cuts across it at a slant. the apparent uidth of the penubral fringe displayed upon the segant is stretched by the slant. In this segant is stretched by the slant. In this paper the intensity distribution along a slanting traverse of a penuabral shadow edge is conputen, the st. atistical distributions of
inaf-udye aliy les at the ends of seymeuts are analyzed, and these two distributions are conbined into a statisticaliy-averaged intensity distribution along the seguent, the distribution being dependent upon the seguent length. When this intensity distribution is incorporated into the segment length

distribotion from the preceding paper of this series, a useful prediction is obtained for the coaplete distribution of intensity within the complete distribution
a plant canopy. (Auth.)

a plant canopy. (Auth

COnHET: Theoret Ical analysis that could have sono a s6essuent applications. Howerer. 1n teras. of photosynthesis prediction the penuabra effects do not contribute significantiy.

$\langle 126\rangle$

willer, E.L., and D.D. Shrader. 1976. Moisture conservation potential with conservation tillage treat ents in the thick loess a rea of vestern Iova. Agron. J. $68(2): 374-378$.

ABSTRACT: holsture is usuaily in short supply for production of corn (ZEA ahis L.) on thick loess derived soils in vestern Iowa. Ilaclices lhat cuiber te mulstile plivild increase crop pields but quantitative data is very scarse. The objectives vere to develop a yield response curve for voisture applicable in vestern Iova and evaluate the potential effect of conservation tillage systees on corn yields. Conputerized nodeling tochnigues vere used to develop the piela

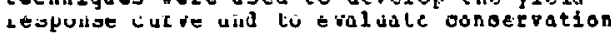
pract ices. noisture stress indices. which pract ices. Hoisture stress indices, vich yields, vere used to evaluate the yefuctiveness of modeled tillage treataents effuctiveness of modeled tillage treataents daily soil noisture use based on initial soll coisture aeasutelents, actual weather data. and siulated hydrologic processes. The approprlace hydrologic processes nere modified to approxiate the tillage syste under study. The hydrologic processes assumed ost altered by conservation tillage anagement ere surface runof and surface evaporation in the spring fallow period. The evaporation in the spring fallow period. The three assuned spring soll wolsture levels in conbination ith actual long tera veather conbination with actual long tera veather records. Then spring soll woisture levels
vere at 100 of the plant-avallable vater vere at $100 \%$ of the plant-avallable vater
capacity (PARC). tillage practices had little effect on estinated corn yields. it the wediua and low spring soll molsture levels. aodolod conservation tillage was effective in increasing yield estiates over those 


\section{APPENDIX A \\ Agricultural Models (continued)}

$\langle 126\rangle$ CONT.

obtalned with conventional tillage. (huth.) MODEI TYPQ: paranetric

COAHEN ?: Enpirical oodel that could be adapted for assegsent of technologi iapacts in vestern Iova.

〈127>

alller, J.E.. J. Hassett, D. R. Koeppe, G.L. Roife, id G. L. Theoler, 1974 . pefferts of
soll properties on $p b$ uptake by corn and soll properties on Pb uptake by corn and ef fects of Pt and Cd on corn root elongation. the environsent, pp. 290-296. LBL-3217. Lawrence Berkele $y$ Laborator . Berkeley, $c A_{\text {. }}$ 365 pp.

ABSTRACT: The uptake of $P b$ into the shoots of six veek-old corn plants was found to decrease with an increase in soil $\mathrm{pH}_{\text {, cation }}$ exchange capacity (CEC), and available phosphorus. The $P b$ effects on grouth of the corn plants were not as clearly related to these soil properties as vas the uptake of po. 1though the greatest reduction of grouth was seen in the low CBC and low pH soils. In was seen in the low CBC a nd low pH soils. An experiwent on corn root growth ind ica concentrations of $\mathrm{Pb}$ and ca which by did cause an inhibition ven added together. A prelininary aodel of the $P b$ and cd effects on root growth is presented. (Auth.)

HODEL TIPE: parabetric

CCHAEN: An exponential grovth function with a growth rate paraneter cependent on caduium and lead concentration could be adapted for assessment purposes.

$\langle 128\rangle$

Miller, P.C. and R. A. Stoner. 1976. R nodel of st and phat as h. Stoner. 1976. haode tundra at Barrow. Alaska. Bcology 57:411-430.

ABSTRACT: 1 medel of radiation, alr tenperature. and vapor denstty in the regetation canopy plant water relations, and photosynthesis. developed in the priary production research prograw of the o.s. Tund ra blone. I described and results for the years 1970 da $11 y$ courses of direct and diffuse solar radiat 10n: infrared radiation: uind: ir temperature and hunidity; leaf tenperatures: convectional and transpirat ional exchange by leaves, steas, and dead aterial; leaf $H(2) 0$ leaves, steas, and dead aterial; 1 eat content, leaf vater potential: leaf
resistance to to $c o(2)$ diffusion: and net photosynthesis. Cli wate varied fon year to year: 1970 and 1971 vara si, $191,1,5,1972$ vas telatively vara
and dry and 1973 was relat ively cold and wet. oi ant paraneters vere obtained for CAREX AOOATILIS. D UPONTIA PI SCAERT ERIOPHOROH ANGOSTIPOLIUH, and SALIX PULCHRA. teaf a rea indices varied by species and by year. Leaf areas of all species vere louest in 1973 . Of the 1 nconing solat radiation approxinately $20 x$ is refiected back and $32 \times-538$ absorbed by the canopy, increasing $32 \times-538$ absorbed by the canopy, increasing
with leaf area index. In the canopy 5-10 ti wes more heat is lost by convection than by evaporation. Total seasonal vascular plant evaporation. Total seasonal vascula $C O(2)$ uptake ranged fros $400-627 \mathrm{~g}$
CO (2). D(G)**(-2) (subscript G refers to ground). In 1971 cupette estiales for total se asona 1 vascular plant $C 0(2)$ uptake vere 602 while the nodel predicted 627 . Indivilual species incorporated about 49 co (2) . I (G)*(-2).day(-1) at nost. The daily Co (2) incorporation vas larger than the dounuard $\operatorname{co}(2)$ flux frow the at uosphere. ioplying that soil respiration is a source of increased with solar 5 adiation. alr and ground tew re ratures, and alr vapor density and decreased with increasing infrared radiat lon for the $s \mathrm{ky}$ and root resistance to vater uptake. Pactors increasing transpiration vitbout alrectly affecting photospathesis tead to decrease photosynthesis because of the effect on vater stress. Net photosynthesis is higher at the top of the canopy, In spite of core farorable ten peratures within the canopy. because of light liajtation. rotal accualted carbon doxide, after subtracting growth costs of leaves. becones positive late in the season and is highest at the lover levels because of the longer duration of leaf area at these levels. Photosynthesis seeas adjusted to laxinize carbon gain under the cost frequent conditions but not under all conditions or extrene conditions. (kuth.)

MODEL TYPE: nechanist1c

COnBET: Tery useful oodel that could be applied in assessuent of technology effects on crop vater use and photosynthesis.

$\langle 129\rangle$

rolz, P.J. and I. Reoson. 1970. Extraction ter codels of soil oisture use by transpiring plants. pater Resour. Bes. transpiring plat

ABSTRACT: A atheatical model is developed describing aoisture renoval from soil by the roots of transpiring plants. The model uses a acroscopic extraction tera in the one-dinensional soll woisture flov equation. it describes both of sture renoval by the plant and induced noi sture covenent through the soll. A numerical procedure based on the Douglas-Jones predictor-corrector nethod is ased to solve the model, and solutions are coapared vith experinental data. The results indicate that extraction ter. nodels are conputationally and physically feasible and give insight litio the aechanics of the

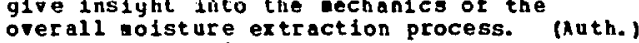
MODEL TYPE: mechanistic

COHEST: Basic physlological aodel for understanding plant aechanisas. Not recouended for assessuent.

$\langle 130\rangle$

Molz, P.J.. and I. Reuson. 1971. Application of an extraction-tera model to the study of coisture flov to plant roots. Agron. J. 63:72-77.

ABSTRCT: one-diansional extraction-tera wodel is used to sinulate the aoisture flow and renoval process in the vicinity of plant roots. The dependence of nodel results on root depth and soll type are investigated. Holsture contents, root noi zture absorption rates and soll-nositure fluxes are conpated and discussed for several hypothetical root systeas in a sandy soil and in a clay soll. The model is solved numerically with a procedure based on the Douglas-Jones predictor-corrector method. Results indicate that olsture extraction by the roots fron soil in their insediate vicinity is the doainant process with Darcian flow in the doainant process With Darcian flow in root zone playing a smaller but often
significant role. gxtraction-tera nodels are vignificant role. Extraction-tera nodels ar

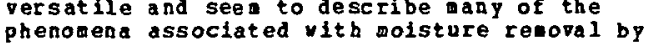
the roots of transpiring plants. (Auth.)

MODEL TYPE: uechanistic

connENT: Physiological aodel that could be incorporated into a are conprehensive codel of soll-plant vater flow. As it stands the aodel has little direct application for assessment purposes.

$\langle 131\rangle$

Honteith. J.L. 1965. Light distribution and photosyothesis in fleld crops. Ann. Bot. Ns
29: $17-37$. 


\section{APPENDIX A \\ Agricultural Models (continued)}

(191) cont.

ABSIRACT: In a new aodel of light distribution in field crops, a paraneter $s$ is the fraction of light passing through unit leaf layer vi thout interception. Radiation profiles me asured with solarineters and photocells give values of $s$ fron 0.7 for $g$ rasses to 0. for species with prostrate leaves. Knoving $s$ leaf transaission tau and lea $f-a$ rea inder S. the 1 ight aistribution in a field crop aay be the light distribution in a field crop aay for (s+(I-s) tau)l. To calcula te crop forg ( $+(I-s)$ taull. To calcula te crop
photosynthesis at given light intensity this expansion is combined vith tro paraneters describing the shape of the light-response curve of single leaves. pinally, the as suapticn that solar radiation varies sinusoidally allou da ilp total

photosynthesis to be estiated frod dayleng th and insolation. The theory predicts about

the sa ae potential photos ynthesis in a cloudy temperate clinate vith long daps as in a aore sunn equatorial climate with short days. shen equ, photosynthesis increases as $s$ Then $\mathrm{L}<3$, photosynthesis increases as
decreases. 1.e. as leaves becone more prostrate; but when $L>5$, photospnthe ${ }^{2}$ increases as 5 increases, 1.e. as Iea ves becone sore erect. Assuing that respiration is proportional to leaf area, estimated dry-matter production agrees vell with field measurenents on sugar-beet, sugar-cane, kale, and suhterranean clover. Estiades of aa ximun gross photosynthesis (for sugar-cane and aaize) Iange froa 60 to $90 \mathrm{~g} / \mathrm{m} * 2 / \mathrm{dag}$ de pending on insolation. (Auth.)

Monel pending on insolat

cOMk $T$ : verg useful sodel that has been incorporated into plant grouth godels. Could be applied to evaluate technology effects on the leaf overlap paraneter $s$ and canopy photsoyntheais.

$\langle 132\rangle$

Murphy, B.D. 1976. The influence of ground cover on the dry deposition ra te of gaseous materials. OCCHD/CSD-19, Oak Ridge Mationa Laboratory, Oak Ridge, Ti 37748 .

ABSTRACr: gaseous pollutants such as so (2) on vegetated surfaces. Prom the discussion there follows a scheme $f$ or calculating deposition velocity. Th is scheme takes in to account the equally

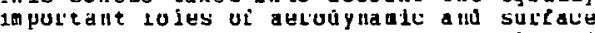
processes. In treating the surface-dependent prt of the problea, we have ident ified those features which are of aajor inportance and ve discuss their faraneterization. Results, derived for typical situations, shov the maner in which the kind and condition of surface cover affects deposition rate. The surface cover affects deposition $r$ ate. The concluding section points out the necessity for empirical validation, particula
the case of forest cover. (Auth.)

nODeI.

CCMnEN: Dseful model for pollutant deposition on to vegetated surfaces.

$\langle$ 133>

Wa ka ha, Y.. ana R. P. Aurrenann. 1991. statistical ae thod for anal ysis of diffusion in soils. Soil Sci. Soc. Aa. Proc. $35: 397-402$.

ABST PACm: A special Monte zarlo aethod for use in investigating problems ubich involve randon procesees is developed. This approach differs from the usual nonte Carlo othod for solution of differential equations in that the random process itself is constructed direct 17. The pcuer of this approach is de monstrated by application of the ethod using two exanples. In one case, the effect of thermal gradient on lonic diffusion through thin films of interfacial water in frozen clay is examined. The predicted ionic distribution is in agreenent both vith excerinental data and vith the result obtained by exact solution of the diffusion equation. In the second exanple, the distribution of acetone deposited in soil near the soil-atmosphere interface is calculated for a tro-layer profile in vhich the adsorption coefficient and void-porosity vary between horizons. ( 1 uth.)

(1) statistical

COMnENT: Research aodel that could be adapted to evaluate pollutant gas movenent into soil.

$\langle 134\rangle$

MaNagara. T., R.E. Phillips, and J. E. Leggett. 1976. Diffusion and ass flow of nitrate-nitrogon inten rnrn rante graun nnder field conditions. Agron. J. 68:67-72.

ABSTRACT: Nitrate-nitrogen, the most inportant source of $N$ of non-leguainous plants, is soluble in soil iater and is transported to soluble in soil water and is transported to plant roots by both ass flow and diffusion. It is, therefore, inportant to evaluate the

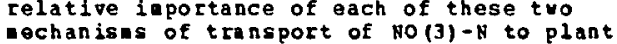

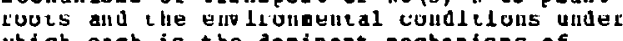
which each is the doainant mechanisas of transport. The objective of this paper vas to present veasurevents of plant and soll parameters necessary for estiaating conditions vith the use of a theoretical aodel and to coupare estilates of accuaulation of $\mathrm{N}$ in the corn plant vith aeasured accumlation in the plant. Plant and soil paraueters vere measured $37,49,76$ and 97 days after planting on corn grown and 97 days after planting on corn grous under field conditions for use in the the pooto. Whe plant and ooll perenotore weasured were volunetric soll water content. concentration of No(3)-N in soll solution. porous diffusion coefficient of no(3) $-\mathrm{N}$ in soil, average nacroscopic relocity of soil. vater at plant root surface, radius of root, transpiration rate, and plant root length. In the derivation of the theoretical odel it vas assuned that the flux of No(3)-N into the vas assuned that the fux of NO (3) - H in the soll solution surfounding the root: the constant of proportionality. $k$. root: the constant of proportionality. relating these two quantities has been
befect root." Alinear relationship between flux and concentration yas found to exist up to. concentration as high as 160 alcrogran NO(3)-N/Cn*\#3 of soil solution for corn grown under field conditions. The proportionality constant, $k$, was found to decrease with tine and/or age of the plant; $k$ values of 0.51 . 0.35 and $0.26 \mathrm{co} * 2 / \mathrm{sec}$ were found for three haryest dates corresponding to 34 to 49 , 49 harvest dates corresponding to 34 to 49 . to 76 , and 76 to 97 days after planting, uptake of $\mathbf{N}$ as conpared $v$ th aeasured accuaulation vere as large as $50 x$ for the individual harvest periods. Hovever, the error vas greatly reduced when the predicted values and neasured values vere suned over The three harvest perinds. In general, the predicted uptake values vere smaller than the measured values when the measured values of accumulation vere less than $1,200 \mathrm{~g}$ of H/plant: the reverse as true wen the Heasured ralues of accunulation were greater measured ralues of accunulat

MODEL TYPE: mechan istic

ConnzHT: Set of parameter values deterained for corn could be used in assessaent applications.

<135>

Nimah, M.N.. and R.J. Hanks. 1973. Hodel for estianting soll vater, plant, and atrospheric interrelations. I. Description and 


\section{APPENDIX A Agricultural Models (continued)}

〈135> CONT.

sensitivity. Soll sci. Soc. Aa. Proc. $37: 522-527$

ABSTPACT: aodel and $i$ ts nuerical solution vere developed to predict vater content profiles, evapotranspiration, water flov fron or to the vater table, root extraction, an root vater potential under transient field conditions. Soil properties needed a re hydraulic conductivity and soil water potential as functions of water content. plant properties needed are root ing depth and liniting root water potential. Cliatic properties needed are potential evaporation properties needed are potential evaporatio and potential transpiration. The node oxtracticn, evapotranspiration, and drainage due to the $\nabla$ arlations in pressure head-vater content relaticns and root depth. Variations in the lisiting root water potential had a swall influence on eatiated evapotranspiration, drainage, and root extraction. (Auth.)

MODEL TYPE: aechanistic

CCHAEN: Hodel does not allow different soil hrdraulic properties for layered solls and ha 1 imited fiexibility.

〈136>

Niah, M.N.. and R.J. Hanks. 1973. Model for estiating soil vater. plant, and atmospheric interrelations. II. Pield test of nodel. So il Sci. Soc. Aw. Proc. 37:528-532.

ABSTPACT: A wathenatical nodel was developed to predict water content profiles.

evapotranspiration, vater flow fron or to the we ter able, root extraction, and root uater potential at the surface under transient potential at the surface under transient onditions. The model vas field tested in
1970 and 1971 . Nith alfalfa (HBDCAGo sAmI L.) as the crop, predicted and computed water content-depth profiles show best agreesent 48 hours after any water addition. The poorest agreement for all crops tested was right after irrigation. The conputed cuaulative up ward water flov from the vater table was $4.80 \mathrm{~cm}$ as cospared to $0.0 \mathrm{ca}$ seasured for the vole 1971 season of 116 days. (Auth.) MODEL TYPE: aechanistic

cory $T$ : Dseful dat source for assessuent applications involving alfalfa on sandy loa soils.

〈137〉

verman, J. H. E. E. Miller, and C.B. Tanner. 1971. Light intensity and sunfleck-size Aistribations in plant canopieg. Agron. J. $63: 963-748$

ABSTRACT: A theory predicting the gap-size distribution of a canopy of horizontal. az Inuthally symetric, randouly located, flat leaves of an $y$ shape is cospared to leaves of an 7 shape is cospared to teasurements in sumac (RHOS TYPHINa L.).
su nf lover (HELIANTHOS ANHUOS L.), and an sunf lover (HELIANT HOS ANHUOS L.), and
artificial canopy. Light intensity artificial canopy. Light intensity
distributions of the solar bean conponent on a horizontal surface belon these canopies are predicted by combining the gap-size distribution theory vith penunbral effects of the finite solar disc. These predictions of the beam-conponent distribution are then co bined uith arer age diffuse penetration theory and a nev scattering theory to produce theory and a new scattering theory to prod a final light in tensity distribation for light sensor in visible and near-infrared light sensor in visible and near-infrared walength bands. The agreeaent is good and in canopies only 2 in helght. (Auth.)

MODEL TYPQ: פechanistic

C CHAENT: Provides physical relationships that could bo included in wole plant models. This detail is probably not needed in as sessuent applications.
<138>

O'Connor, G. A., M.T. van Genuchten, and P.J. ilerenga. 1976. Predicting 2,4,5-T dovenent in soil coluans. J. Environ. Qual. 5:375-378. ABSTRACT: A solute sodel developed by pan Genuchten and lierenga us used to calculate 2,4,5-T effluent data froe soll coluans. The nodel had been previously shown to adequately predict effluent data given oodel paraneters curve fit to a portion of the effluent curve. The present work shows that $2,4,5-T$ effluent curves may be adequately predicted without prior knovledge of the effluent curves for a particular soil coluan given: (i) nodel paraneters derived from 2, 4,5-T effluent curves for other soil colunns, or (ii) nodel parameters obtained frou tritium effluent curves for the same coluens. The dat suggest that once the physical model paraneters have been characterized for a soil. reasonable predictions of $2,4,5-T$ (and perhaps other solutes) transport can be ade given the adsorption coefficient for the solute. (Auth.)

HODEL TYPE: echan ist Ic

COAHET: Oseful for simulation of cheaical morement through soil colunns, but cannot be relled upon for field chemical behavior.

<139>

O'Gara, P.J. 1922. Sulfur dioxide and fune problems and their solutions. J. Ind. eng. chem. 14:744.

ABSTRACT: A seven year study of so(2) effects on the grouth of about 200 plant species under varying field conditions of light. texperature. hunidity and stage of growth has resulted in the discovery of the law of gas action on the plant cell." This lav states that with all environiental factors renaining the same, the active part of a gas necessary to produce a certain effect on the plant celi. aultiplied by the tiae through which it acts, is constant.

MODEL TYPE: parauetric

COHABT: This law has been used extensively to represent pollutant effects.

$\langle 140\rangle$

O'veill, R.v., and 0.R. Burke. 1971. A sinple systens oodel for DDT and DDE wovenent in the huna $n$ foodchain. ORNL-IBP-79-9, Oak Ridge Nat ion al Lab.. Oax Ridge, TH.

ABSTRACT: This report documents a model of DDT and $D D E$ movenent in human foodchains. The oodel vas developed fron data supplied by the Advisory Cosnittee on DDT, Bnvironaental Protection Agency and at tempts to forecast pesticide concentrations in man under alternative assuaptions about DDT application in the onited states. (Auth.)

MODEL TYPE: paranetric

COBMENT: The method could be adapted to assessnent of energy technology inpacts.

$\langle 141\rangle$

ossan, A.H. 1971. Dry-aatter production of a wheat crop in relation to light interception and photosynthetic capacity of leaves. Ann. Bot. 35:1017-1035.

ABSTRACT: In a weat crop in the field, the relationship between leaf-area index and the transolssion of visible, infra-red, and total radiation vas found to be close to Beer's law: hoverer, there was an indication of curpilinearity in the visible radiation profile at the botton layers of a dense crop. The extinction coefficlent for visible, infra-red, and total radiation was found to vary wh tive in a less dense crop. $s(\nabla)$ the fraction of visible radiation that passes 


\section{APPENDIX A \\ Agricultural Models (continued)}

〈141> CONT.

through unit leaf layer without interception, vas found to increase with increase in the leaf-area index of the two crops. The monteith model was used to calculate the gr oss phctosynthesis of leaves. The contribution by stens and ears and the respiration losses of all organs of the plant vere taken into account vhen calculating the dry-weight increases and the $i$ portance of their pariation vas assessed. A satisfactory their variation was assessed. A satistactory agreenent betveen the estimated and neasura variation in the extinction coefficients and variation in the extinction coefficients and
$s(v)$ on gross photosynthesis of leaves was $s(v)$ on gross photosynthesis of leaves
explored. The variation in the visib lo radiation-response curves of different leaves vas found to have a large effect on the gross photosynthes is of leaves. The total respiration of the mass of leaves in the canopy was found to be of great significanec in dry-veight increases. A general dependence of the dry-matter production of the a sount of total incoming visible the a wount of total incoming

Mopriti pyrn: meclioniatis

COMBE T: This is an apflication of the Monteith (1965) model.

$\langle 142\rangle$

Page, E.R.. and A. Gervitz. 1974. Ma the datical nodels, based on diffusion equations, to describe root systens of isolated plants, rou $c r o p s$, and suards. Plant Soil 41:243-254.

ABSTRACT: Matheratical nodels to describe the density cf plant roots in the soil have been density cf plant roots in the soil have

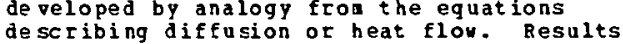
describing diffusion or heat flow Resu ft of an experisent with isolated plants (lettuces) shows that the equation for diffusion from a point source applies, vhile that wien allowance is ade for the assynetry resulting frod a preferred direction cf grouth, the equation describing diffusion from a line into a seai-infinite aediua can be applied. Results reported by other vorkers for ryegrass are used to deaonstrate that for a suard the appropriate equation is that describing diffusion fron a plane into that mi-infinite nedius. (Auth.)

MODEL TPPE: parametric

Conn T: hodel is not directly applicable in as sessment.

$\langle 143\rangle$

Paltridge, G. 1970. A model of a groving pasture. Agric. Neteorol. 7:93-130.

ABSTRACT: An attenpt is made to model a developing pasture in a waner requiring no The term "pasture" here includes all forms of un ifor vequtation which can be chacterized primarily by leaves and roots. The nodel is primarily by leares and roots. The model is any time at a particular level in the canopy. growth is deterained by one of three pa raneters (radiation arailable, carbon dioxife available, or the capacity of individual leaves to carry out the photosynthetic conpersion which ar calculable froa the defined above-crop external conditions and the paraneters of the plant wich have been selected as plant which have been selected sol in depen 3 . on field data, it is possible to use siapla evolutionary constraints to enable the pasture to generate its own architecture as the ohotosynthesized aaterial becoaes arailable. Soil water status is incluled, so that the effect of vater deficit on the growth pattern of both leaves and roots can
be investigated. The trials of the nodel so far have not been true simulations in the sense that the leaves and roots have been identified with a particular crop. Hoverer. the wost obrlously useful agroneteorological concepts have been incorporated, so that for a particular siaulation at teapt it is only necessary to devise suitable physical descriptions of leaf shape and orientation which at the save time enable calculation of the necessary dependent variables ffor instance, the rertical wass transfer coefficient and the $r$ adiation flux).

Illustrative trials of the nodel conpare vell Iilustrative trials of the nodel conpa (in those aspects the re comparison is possible vithout direct simulation) with real pastures, and reveal behaviour-patterns which a ay help to direct experiaental research in the field. (Auth,)

MODEL TYPE: uechanistic

COnAENT: Research todel addressing physiological questions and not suitable for assessaent.

$\langle 144\rangle$

Paltridge, G. H.. and J.V. Denholim. 1974. Plant $y$ ield and the swich from regetative to ceoroduetive orouth. W. Theirl, nigh. 44:23-34.

ABSTRACT: hany plants have fairly sharp division between their vegetative and reproductive phases of yruwth. Switch-over does not necessarily occur at the optian time, and the resultant drop in yield ay be essentiallg independent of any variation in basic photosynthetic ability. If this is so, it way be nec essary to conpare the seasured yield in any agricultural trial with the equivalent optimu yield for the particular croivalent optiau 91 basic for the partical aodel of a two-phase systea is developed which involves tho-pates of growth of grean aterial and the rates of growth of grean aterial and
grain, and takes leaf senescence and the effect of the environnent on photosynthesis into account. The application of the eodel is discussed by reference to a vell-docusent ed what crop. (Auth.)

MODEL TYPE: wechanistic

COMHENT: hodel designed to exanine physiological questions and not suitable for assessaent.

《145>

Parkhurst, D.P. P.R. Duncan, D. M. Gates, and $P$. Kreith. 1968. Dind-tunnel aodelling of convection of heat between air and broad leares of plants. agric. neteorol. 5: 33-47.

ABSTRACT: A wethod is described for calculating convection coefficients for thin broad leaves of arbitrary shape, using existing equations for rectangular flat plates.

Electrically-heated rodels placed in a vind

tunnel provide experimental support for the

aethod. Effective dimensions for several

real and idealized leaf shapes are presented. Experimental data frou long. narrou leat aodels shoy that convection in flow perpendicular to the leaf surface may be almost double the value for parallel flon. Three exaples are discussed. (Auth.)

MODEL TYPE: paranetric

COMAET: Useful method to fnclude in aodels of plant-physical environgent interactions.

$\langle 146\rangle$

Passioura, J.B. 1963. A mathematical sodel for the uptake of ions from the soil solution. Plant Soil 18:225-238.

ABSTRACT: A nodel is developed in which the uptake of ions wich exist wolly in the soil solution is described in teras of their net wovepent towards the surfaces of roots. The or in the mass flov of water tovards the roots, and, given these two ways of noveent. the model is tased on five main assumptions. The validity of these assumptions is 


\section{APPENDIX A \\ Agricultural Models (continued)}

$\langle 146\rangle \operatorname{con} T$.

discussed, together with sone of the model's inplications, and a few experiments are suggested ty which it could be tested. (A ath.)

HODEL TIPE: sechanistic

c chMEN $\mathrm{T}$ : in early odel for solute uptake that ha $s$ been superceded by later developments. eg. Baluin Nye and Tinker (1973).

$\langle 147\rangle$

Patefield, M. H.. and R.B. Austin. 1971. A model for the sivulation of the growth of BETA VILGARTS L. Ann. Bot. 35: 1227-1250

ABSTRACT: A simple explanatory nodel for the si uulation of the growth of BET $A$ is descrihed. It takes account of photosynthesis, respiration, and the light-intercepting properties of the follage: but uses the observed distribution pattern of dry watter. A crof of BETA was grown and. by periodic sanpling of plants. qrowth curves we obtained. These are coapared with si ulated grovth curves and the reasons for the discrepancies are discussed. Pron sinulations with different values of the constants of the aodel, the effects on yield of variations in these constants are predicted. ( $A$ uth.)

MODEL TYPE: parawetric

CCMMBrT: Model could be adapted for assessuent of impacts on sugar beet crops.

$\langle 148\rangle$

Penning de vries, P.T. 1972. A adel for si wulating transpiration of 1 eaves with special attention to stomatal functioning. J. APP 1. 8C01. 9:57-77.

ABSTRACm: A dynaic model of a vater-containing an 0 ater-conduceing syseew is described representing a non-groving. transpiring leat with an attached root in a nutrient solution. The sfuulated transpiration rate is deterained by environental conditions and leaf conductivity. the latter being naing under stonatal control. A hypothes is of under storat functioning based upon the stonatal functioning based upon the interaticn between guard cells and subsidiary cells is presented. The control aechanise of the guard cells is supposed to be affezted both by present and past plant vater status. liaht intensity and $c o(2)$ concentration in the leat. Which depends on photosynthesis and diffusion rates. The functon of subsiliary cells is taken to be affected only by present and past plant water status. Experinents are simulated to evaluate the oodel. The nodel is written in the coaputer siulation language csap and is presented in such a wa that the added listing of it ay be that the added listing of it aa 9 be understood after studying this paper without
previous knovledge of programing. (Auth.) Mocet TYPE: nechanistic

CCHBRT: similar nodels are available. This vork is oriented to physiological research rather than assegenent. hut conld he adapt, ed to evaluate sove technology inpacts.

$\langle 149\rangle$

Rai, D... and W.L. Lindsay. 1975. theraody na aic aodel for predict ing the foration, stability, and veathering of coamon scil dinerals. Snil sci. So. Aa. proc. 39:999-996.

ABSTRACT: Numerous vorkers have exanined the we athering products of soil ainerals and have proposed eapirical weathering sequences. The present paper outlines the developnent of a thersodynalc oodel that predicts in a sisteratic vap several ineral sp steqatic way several aineral in sol According to this aodel, the stability of primary anerals increases in the order:
Ma-glass, R-glass, Pyroxene, analciee, anorthite, low albite, muscovite, alcroclibe and quartz. The stability of secondary clap - inerals depends on soluble silica. At pH 6 vith high silica (nearly equals $10 *(-3)$ h) the order of increasing stability is: chlorite, halloysite, glbbsite, illite, dickite, beidelifte, kaolinite, and montuorillonite: at lov silica (nearly equal $10 *(-5)$ a) the order is: chlorite, hall nysite, lilite, boidolito.

nontmorilionite, dickite, kaolinite, and gibbsite. The stability of both prinary and secondary ainerals increases vith $p H$. The observed veathering of volcanic ash agrees well with the predict lons of this aodel. The -odel makes use of important thermodyanic dat accuaulated for soll inerals and helps to pinpoint deficiencies in these data. The need to exanine the kinetics of aneral transforations in solls in greater detail also becoses obvious fron this nodel. (Anth.) MODEL TIPE: pechanistic

COABET: The Al-si diagras predicting aineral forcation ay be useful in evaluation of acid Iain and/or pollutant effects on soll inerology.

$\langle 150\rangle$

Reed, R. L., and R.R. Maring. 1974. Coupling of environment to plant response: $A$ simulation odel of transpication. Bcology 55:62-72.

ABSTRACT: A lou-resolution sinulation codel of transpiration was developed and run, vith. transpiration was developed and run, vith oregon. The output of the sodel served as a -eans of relating environtental variables to plant response. This relation vas used to define an ordinate vich. In conjunction with prevlously developed ecosyste ordinates, proved helptul for conparing ecosystens. predicting comanity coaposition and, in special cases, growth. The data reguirements of the aodel are nodest: ve deliberately dereloped a model that can be used on dat a obtained fron field studies where electric pover is unarailable and use of sophisticated pover is unarailable and use of sophisticat instrumentaticn is in possible. The aodel at ospher ic hualdity, seasonal plant uater potential (expressed as plant noisture stress, the absolute palue of plant water potential), and a model of stomatal behavior. Where it vas iapossible to obtain accurate data, stochastic nodels vere used to provide the necessary input. The model sioulated botb potential and actual transplration, the ratio of uhich is the nost valuable single inder of the seasonal oisture regine. Wher no asurable stonatal control vas exerted by no measurable stonatal control was exerted that adequate vater vas avaliable to eet the transpiration denand. The ratio approached 0.3 on the drier locations. Significant changes in vegetation and growth were associated with this index. (Ruth.)

HODEL TYPE: para metric

conarr: could be useful in assessnent where lifited data are apailable.

$\langle 151\rangle$

Reiners, R.A. 1968. Carbon dioxide evolution froa the floor of three ninnesota forests. Prolngy Q9:471-4A3.

ABSTRACT: Carbon dioxide evolution rates fro forest floors, wasured approxilately weekly for 54 weeks in oak forest, arginal fern, and cedar swa ap. vere closely related to soil tenperature and secondarily to molsture conditions. As a result, icroclieatic and drainage characteristics of the three forests produced beasonal if ferences in carbon produced Beasonal diferences in carbon
release. However. conpensatory factors release. How ever, conpensatory factors
produced nearly egual cuaviative annual 


\section{APPENDIX A \\ Agricultural Models (continued)}

<151> CONT.

totals of $C O(2)$ evolution. Total co(2) erolution was over three tines higher than expected frow an equivalent asount of carbon release frow annul litter fall. Respiration by tree roots us suspected as the ajor contributor to this disparity although me thodolcgical probles related to floy rate are still open to question. (Auth.)

nODE I TYPP: regression

COHM T: Pegression function could be used in a carbon budget model.

<152>

Ritchie. J.T. 1972. hodel for predicting evaporaticn from a row crop with incoupleta cover. Nater Resouf. Res. $9: 1204-1213$.

ABSTRACT: A model is presented for calculating the daily eraporation rate from a crop surface. It applies to a ron crop canopy situation in wich the soil water supply to the plant roots is not limited and the crop ha $s$ not come into an advanced stage of maturaticn or senescence. The crop ev aporation rate is calculated by adding the soil surface and plant surface components leach of the se requiring daily numbers for the leaf area index). the potential evaporation, the rainfall, and the net radiation abore the canopy. The evaporation frou the soil surface $E(5)$, is calculated in tro stages: (1) the constant rate stage in wich $B(s)$ is linited only by the supply of energ tc the surface and (2) the falling energy tc the surface and (2) the falling rate stage in which vater movenent to controlled by the hydraulic properties of the soil. The evaporation froa the plant surfaces $L(p)$ is prealcted by using an expirical relation based on local data. which shows how $P(p)$ is related to $E(0)$ through the licaf a rca index. The aodel vas used to obtain the total evaporation rate $E=E(s)+E(p)$ of a developing grain sorghu (SORGHor BI color t.) canopy in central Teras. The results agreed vell. with values for $E$ measured directly with veiqhing lysimeter me asurea

MODEL TYPE: Dechanisti

C CMHENT: Very useful odel for assessaent of agricultural impacts.

$\langle 153\rangle$

Rogovski, A.S. 1971. Matershed physics: Model of the soil voisture characteristic. Mater pesour. Res.7: $1575-1582$.

ABSTRACT: The procedure is proposed by uhich reasonable estinates of the soil goisture reasonable estiates of the soil aoistur characteristic can be obtained hen a content and essure at air entry and at 15 content and pressure at air entry and parancters. The paramcters are easily deterained and at tiaes can be readil abstracted from literature or estinated from published data. Applicability of the codel is tested on graded sand and eight soils. (A uth.)

(A uth.)

COHA T: Iseful nethod for representation of soil hydraulic proferties required in soil soil hydraulic pro

$\langle 154\rangle$

Rogouski. A.S. 1972. Estination of the soil mo isture characteristic and hydraulic conductivity: Ccmparison of models. Soil Sc i. $114: 423-429$.

ABSTRACT: Three vays of sodeling the soisture characteristic and tro vays of nodeling characteristic and tro vays of aodeling and compared. It is concluded that a andified Brooks and corey conductivity wodel
(LBC), and the noisture characteristic associated with it are guite similar in fora to a oodified (ASR) pore-size interaction godel of Green and corey. The results fron both compare vell with experimental values at higher molsture contents. Hovever, the ASR oodel approxilates the experiuental results better at lower values of water content and over a vide cisture range. The moisture content and pressure at air entry appear to be significant paraneters of the soll water systea. A linear model of the soil noisture character ist ic underestimates experimenta 1 results when used as input into the godified pore-size interaction oodel of hydraulic conductivity. (Auth.)

HODEL TYPE: pa ra metric

ZOMAENT: Oseful conparison of aethods for calculating soil hydraulic properties which are needed in models of soil water flow.

〈155>

Roukens, H.J.H., and R.D. Miller. 1971. predicting root size and frequency fros one-diaensiona 1 consolidation data atheatical odel. Plant Sol1 $35: 237-248$.

ABSTRACT: An lmplicit relationship between root size and soil reaction to root growth pressure is developed for a cohestonless soil fron data of one-diansional consolidation tests. The athenatical aodel enployed describes a phenonenological procedure of relating root size and root frequency to soll relating root size and root frequency to sol mechanical parameters. The aodel is based
on: (1) a sioplificaton of the obser red dependency of vold ratio on compression pressure, and (2) the assonption of an inverse relationship over the donain of root influence between the radial stress and the distance frou the axis of the root. As radial expansion of a root proceeds, three successive and athouticalig distidet stagos of root growth are recognized in a preconsolidated soil. Relationships between root grouth pressure and root size vere coot grouth pressure and root size vere conputed for various conbinations of bulk density. preconsolidation pressure, and values of the conpression index in and the range of preconsolination, Ront
frequencies vere calculated for a nuaber of hypothetical situations assueing a hexagonal net vork of evenly distributed roots. (Auth.) HODEL TYPQ: Dechanist 1c

COMnEN : Model could be used to evaluate changes in soil strength or coupression effects on root growth.

$\langle 156\rangle$

Bunge, E.C.A. 1973. Soil development seguences and energy codels. Soll se1. 115:18 3-193.

ASTRACT: The inportance of having an a priori wodel to guide our imaginative thoughts and researcb is desirable in any discipline. This is particularly important in a slouly changing systed under continuous developeent such as soils where the separation of cause. and effect is nost. difficult. A nodel of soll developeent based on energy vectors unelative ill oull is preseritod and

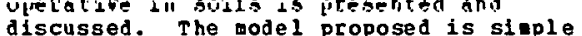
discussed. The rodel proposed is sieple initially but can become as complex as the situation reguires. The model discussed way enable one to design experiaents which have do previous wodels. Also the wodel seens to allor for easier extrapolation of results. Hopefully the proposed model will help in predicting wore accurately the effect of an's activity on solls of the vorld. (Auth.) MODEL TYPE: conceptual

COHAEHT: Could be useful in assessnent to establish qualitative changes in soils induced by technolugy iapact. 


\section{APPENDIX A \\ Agricultural Models (continued)}

〈157>

Russell, J.S. 1976. Conparative salt tolerance of sose tropical and temperate leguses and troplcal grasses. Nust. J. Exptl. Agric. troplcal grasses. 1s

ABSTRACT: The dry atter yield of 11 tropical le gunes, 10 temperate legues and 11 tropical qr asses vas exanined in pot experiments on a cla soll vith increasing levels of sodius chlorile. A athenatical oodel was fitted to the pield-salt level curves for each specles and both the half yield soil salinity level and zero pield scil salinity level we re estluted. Species vere ranked in relation to their salt tolerance at half and zero tield a nd these values were erpressed in terus of the electrical conductivity cf the soll saturation extract. Grasses shoved a greater ability to persist at high salt lo vels than the legunes. The nost tolerant grasses vete CALORIS gRTANA, PANTCMM COLOATU,. PENA ISETON CLAMDSTI ROH, SORGHOH AL gun and DIGITARIA DECUABENS. HEDTCAGO SATIV, which was included in both te sperate and tropical groups, was the wost tolerant lequme of both groups. The tropical legunes MACROPTILIOH LATHYROIDES and HACROPII LIOA HACROPTILIOH LATHYROTDES and HACROPTI LIOA A. ROPORP OREOH vere almost equivalent to h. SA I in their salt tolerance. The least least tolerant tropical and temperate leguses Se AT PI IOSOH, respectively. Both $\mathrm{Na}$ and $\mathrm{Cl}$ percentaces in the plant generally increased with increasing salt but no consistent relationship vas found betreen plant salt tolerance and $\mathrm{ya}$ and $c 1$ content. The field inplications of the high salt tolerance of in certaln grasses is discussed in relation to the establishment of peraanent grass-legu HODEL TPPE: paranetric

COHE T: Si aple and useful approach to evaluate salinity hazard.

<158>

Bpan, J.R., E.A. Garza, and S.L. Brown, 1974. da age 3 ssessment aodel for agricultural cr ops. SRI-260-2729 Stanford Resea IC h Institute, Henlo Park, CA 94025 .

AESTRCT: This report describes the nain feature of a wodel developed for the assessuent of radiation daage to ten aqricultural crops and the PORTRA cosputer progra that inpleaents the crop assessaent model. The ten crops included in the aodel vere corn, sorghum, soybeans, rye, rice, potatos, alfalfa, sugar beets, wheat, and barley. The ob jective of the research was to incorporaze current research results into a sodel and progran for the foint use of the Defense Civil preparedness Agency, the o.s. De partmant of Agriculture, and the office of De partmant of Agriculture, and the office of three aain subwodels: (1) A crop norphology three main subwodels: (1) hrop pa ra netors subadel. that estiales the growth parade at tack date. (2) a radiation dose subrodel that uses the attack effects to estiate the total absorbed dcse and effective dose rate for each crop in the county under

consideration. (3) a crop survival subnodel that estiates the crop pield surviving. based on the dose and dose rate and the growth stage of the plant: The major inpues grouth stage of the plant. The a jor inpues required are crop grovth paraseters, and harvesting dates, and attack data describing the radiation levels. The model
uses these inputs to calculate the percentage uses the se I puts to calculate the percentage model inputs and outputs and PORTRAN progra. vere designed to be compatible with the READY progran of the Hathenatics and Conputation Laboratory of the General services

Ad einistration. The use of the crop ass esseent progran and the results of a saple run are described in the last section of the report. The sample run was intended to provide to potential users a means of checking the laplenentation of the progran on other conputer systess. The sanple output is a lso useful for denonstrating differences in crop survival over the various growth stages. (Auth.)

HODEL TYPE: paranetric

COHAET: Model is applicable to radiological assessant and can be used for these purposes.

〈159)

Saeki. T. 1960. Interrelationsh1ps between leaf asount. light distribution and total photosynthesis in a plant coanunity. Bot. Hag. 73:55-63.

ABSTRACT: In order to find a practical neans of estiration of the production of atter in a plant conaunity and to give a logical explanation to the variablitity of directly measured values. theoretical analyses have been advanced of the inter relationshios betveen leaf anount. light distribution and total follage photosyntbesis. Inside follage relative light intensity received by the leaves is not always the sane as the light leaves is not alvays the saae as the light same height. In honogeneous stands the former same helght. In hologeneous stands the forme
can be derived fron equation (3). when leaf can be derived fron Rquation (3) coefficient ( $K$ in equation (2)) . Is obtained beforehand oy' stratifying clip nethod. If photosynthetic capacity in the active leaf and ean respiration rate of all the leaves in a stand are known, the wean total daily photosgnthesis of uhole follage is estimated by Equation (5). An exanle in representative herbaceous species is presented. where it is clearly indicated that vith lover leaf area ladex. daily production in follage is index dally production in follage is with increase of leaf anount the role of inclination in the production becones very renarkable, upright leares beling nore efficient than horizontal ones under full daylight as demonstrated by vatson and ritts. conpensat loo light intensity and coptisua leaf-area index' (leaf amount in the form of LAI for the highest production) are calculated fron the photospnthetic capacity in the active leaf and respiration rate of the (6quations (6) and (7)). I he the lower leaf (Equations (6) and (7)). The in consideration of the linimu light intensities and leaf area indexes' in the natural conunities. The highest daily pluducllua la a plaul cunauilly. P(adx) : calculated with Equation (B) was discussed in relation to the extinction coefficient and incoling radiation. An approxiate colncideace as recognized between the calculated values and the highest net production in crop fields collated by praduction in crop fielas and Black. (Auth.)

MODEL TYPE: mechanistic

COHAENT: Early odel for crop photosynthesis often used in lore recent crop sinulation nodels. Oseful for assessuent al though more conprehensive nodels are available.

$\langle 160\rangle$

Saver, R. H. 1976. The relationship of cunulative suns and noving averages of cenperature to reproductive phenology in CLARRIA. AD. Hidi. Hat. 95:144-158.

ABSTRACT: Plover ing tine (anthes1s) differs asong populations in the CLARKI DBgoIC OLATh cosplex, and these differences appear to be adaptive with respect to arolding the sepere suner drought of the native habitats. As habitat elevation decreases, flowering tine and soil drying occur earlier. Six 


\section{APPENDIX A \\ Agricultural Models (continued)}

$\langle 160\rangle$ CONT.

populaticns of the $C$. ONG OICULATA coaplex we re groun in four tes peratures to asess the ef fect of temperatue on the timing of five developmental stages (phenophases). Pegressions vere $c$ alculated using the days from planting to a given phenophase (age) as from planting to a given phenophase (age) combinations of moving average lengths, comblative suas, threshold temperatures and cumulative suas, threshold teaperatures means when the parious phenophases occurred as the independent variables. The tiaing of al 1 phenophases vere significantly correlated more of ten vith woving averages than vith cumulative suas, and it took longer to reach a given phenophase at the lover tenpe ratures. The absence of interpopulation and interphenophase differences suggests that the in terphenophase differences suggests the environaents of the native te tperature environsents of the native habitats during flovering are similar and that observed differences in flovering

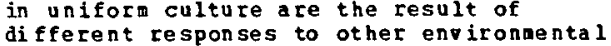
fuctors such as insolation and soil vater potential. Plowering and habitat characteristics are conbined into a graphic model that illustrates the importance of flovering in response to teaperature to avoid sumer drought. (Auth.)

YODEL TYPE: statistical

C CMMENT: Could be used in assessment of climate chanqe on plant phenology.

〈161>

Schuep P, P. H., and R. D. White. 1975. Transfer processes in regetation by electrochenical analog. Bound.-Layer Meteorol. 8:335-358.

ABSTRAT: Blectrocheaical wodelling ay provide fast order-of-aagnitude estiates of energy and mass transfer in crops and partly $f 111$ the gap betreen rigia. expensive fiela experibents and orersiaplified matheratical modelling. The technique comprises breaking modelling. The technique comprises b up a floving electrolyte in a manner similar - to the way the at nospheric flov is broken up by crops and studying the flow of ions in the electrolyte. The effects of variations in free-flor velocity, plant spacing. rov spacing and or ientation on velocity field, transfer coefficients and ed dy difusivities have been stulied in an el ectrocheaical nodel under conditions relevant to vell-ventilated crops with relatively siaple canopy structure. A one-diaensional analptical nodel is developed one-dinensional analptical model is deve for the transfer at solid surfaces, vith di rect proportionality between transfer coefficient and eddy diffusivity. The the model cf 13.5 plus or minus $0.5) \times 10^{* *}(-3) / \mathrm{cm}$ at the ground and (5 p
minus 2$) \times 10^{* *}(-4) / \mathrm{ca}$ (for a cylindrical probel near canopy top. The latter is not too different from the values proposed for foliage surfaces in real canopies, viz.. ap proximately $1 \times 10 *(-3) / C a$ (Philip, 1964) and $7 \times 10^{* *(-4) / C a ~(0 c h i j i a a, ~ 1966) . ~ A l ~ p h a ~}$ and therefore becone a usetul parageter in da therefore becone a usetul parageter in scaling transfer coefficients fou

with different alecular diffusion
properties. A tentative extrapolation of properties. A tentatipe extrapolation of measured data to corresponding values in a
is given. The agreenent between predicted values and presently available field data is en couraging although are precise field data are required for a final judgevent on the vility of the model. (Auth.)

AODEL TYPE: electochenical analog

COH. EN T. Experimental nethod of analog adeling that could be usefully applied in assessaent if facilities vere available. $\langle 162\rangle$

Scott, B.I.H., and H.F. Gulline. 1972. Natural and forced circadian oscillations in the leaf of TRIPOLIOI REPENS. Aust. J. Biol. Sci. $25: 61-76$.

ABSTRACT: The leaves of vhite clover (T. REPENS) exhibit typical circadian characteristics ith an endogenous period, tau, of 25-27 hr. corresponding oscillations are observed of corresponding oscillations are observed of the torque exerted by leaflets prevented fros
closinq. The gean variation in torque during a cycle vas 339 plus or ainus 13 dyne ca. Then leaves vere subjected to light-dark cycles at constant tesperature, entrainnent was obtained for periods from 0.7 to 1.4 tau. Phase shifts vere observed ranging frod a lag of $40 \mathrm{deg}$. for 0.7 tau to an advance of 130 deg. for 1.4 tau. The pulvinus was shoun to be both the photoreceptor and the site of the endogenous tiver. Si uilar responses to those for light vere observed in leaves under for light vere observed in leaves onder constant illueination which experienced 8 and $18 \mathrm{deg}$. C, and betveen 15 and 22 deg. $C$. $A$ athenatical odel is considered of a sinple oscillatory syste ns whose natural oscillations and phase responses to forcing oscillations resebble those of the leaf. It is a cqued that the basic oscillator is linear, producing daeped sinusoidal oscillations, and that the non-linearitios which introduce higher harmonies in the observed leaf oscillation occur in the coupling between oscillator and output. MODEL TYPE: paranetric

coHBEN: Probably not useful in assessaent.

$\langle 163\rangle$

Scrivner, C.L.. J.C. Baker, and D.R. Brees. 1973. Conbined dally cliatic data an dilute solution cheaistry in studies of soil profile foration. sotil sci. 115:213-223.

ABSTRACT: A model yas developed for converting long-time daily records of temperature and precipitation into daily depths of noistening and drying of the soil. The tiee-depth and drying of the soil. The time-depth distributions of noist and dry zones vere sumed and converted to a prediction equation
of the fora, $\log P=k(1)-k(2)+\log D$ where $P$ is the freguency of conpleted aotst-dry cycles: $D$ is depth, and $k(1)$ and $k(2)$ are constants characteristic of a particular soll and clitate. The average annal anount of excess precipitaion that fell when soil ooisture was coapletely recharged cospleted the numerical description of the soil noisture regise. The depth that has a frequency of one coapleted aoist-dry cycle per year coincides vith the depth of solum in issouri soils. It appears depth of solum in the upper boundary of the $D$ horizon is thet the upper boundary of the $D$ hor penetration of suaner rains. Estinated awounts of water passing planes in the soil $c$ an be sumed by integration of the prediction equation for depth-frequency of completed oist-dry cycles. Analyses of soll solutions produced when dry soll saples were equllibrated with water for one veek suggest that alouino-sulicate minerals react in a canner that is predicted by chealcal thermodyanics. Raolinite appears to be the stable clay aineral in a ide arrap of soil horizons including those ith large anounts of montorillonite. Quartz appears to be of montuorillonite. Quartz appears to instable in sone horizons, in layers a gibbsitic soil containing quartz (Auth.)

HODEI TIPE: regr ession

conaEgr: Sinple model that could evaluate cliate change effects on soil profile formation.

(164)

Seginer. I. 1970. A resistance nodel of 


\section{APPENDIX A \\ Agricultural Models (continued)}

$\langle 964\rangle$ CONT.

evaporation during sprinkling. Agric. te teorol. 7:487-497.

ABSTRAC?: A previ ous resistance nodel of sprinkler evaporation is expanded by considering tio energy balance equations: one for the drops and another for the air la yer where the evaporation takes place.
solve for the rarious flaxes, only the boundary conditiong and the resistances of the systes nust be given. A conparison of calculations with experieental results, indicates good agreedent for the liaiting case of a vet surface vith no drops in the air. The codel predicts small spray evaporation under noral operating evaporation under noraal operating fineness of spray and application $r$ ate on the er aporation losses ay be significant. if the variation of any of these parameters is vithin vide linits. (Auth.)

MODPL TYPE: Dechanistic

COME T: Could be used in technology inpact as sessment of cooling towers.

$\langle 165\rangle$

Shaver of $t$, R.H.. R.R. Lgaon, L. H. Allen, D. H. Stewart, and S.E. Jensen. 1974. The soll-plant-atcosphere aodel and some of $i t s$ predictions. Agric. Heteorol. 14:287-307.

ABSTRAC?: A general description of the soil-plant-ataosphere aodel (SPAM) is given. Enphasis is ade as to the logical sequence of the operation of the model by use of various subwodels depicting the soil. plant. and clinatic interactions. Exaples of the te sting of the odel are discussed. Sone siaulaticn studies are given to show hou the bodel can be used in setting priorities on those variables that have the qreatest influence on plant responses. (kuth.) MODE L TYPE: wechanistic

COHA $\mathrm{T:}$ in ieportant oodel with uang applications in the assessuent of environaental effects on crop performance.

$\langle 166\rangle$

Shearer, G.. J. Duffy, D. H. Kohl, and 8 . Comoner. 1974. A steady-state model of is otopic fract ionation acconpanying nitrogen
transfordations in soll. Soil Sci. Soc. An. transfornations

ABSTRACT: A steady-state anthenatical nodel of is otopic fractionation accompaning certain ni trogen transformations in soils is de veloped. The nodel takes into account ammification, nitrification, and im mobilization; and predicts that the $15 \mathrm{~N} / 14 \mathrm{~N}$ ratios of nitrate and anoniua ion depend in part upon tha ratio of the rates of in cohilization and anonification. The ratio of the rates of inobilizaton to

nitrification under field conditions is

un likely to be the sane as under the conditions of laboratory incubation ex periments. Therefore, this prediction provides a possible explanation for differences observed bet ween the $15 \mathrm{~N} / 14 \mathrm{~N}$ ratio of nitrate extracted froo soil cores and that of nitrate released during laboratory incubation of the same solls. The aodel described is anenable to experinental test. If verified, an expanded version of the model ay be a useful aid in the stud of thitrogen transformations in the field. nitrogen
(A uth.)

MODEL TYPE: nechanistic

CCHMEN T: Hodel could be adapted to evaluate pollotant effects.

<167>

Sheedy, J.D., F.L. Johnson, and P.G. Risser.

1973. Model for phosphor as and potassiua flux in a tall-grass prairie. Southvest. Nat. $18(2)=135-149$.

ABSTACT: A hechanistic siaulation model is presented for the dynaics of phosphorus and potassiua in a tall-grass prafrie ecosysten in northeastern oklahoma. Values for certain ablotic factors in 1970 vere used as input to the node1. Output consisted of predicted tiee-series of values for the amounts of phosphorus and potassian present in the different conparteents of the ecosysten. Predicted values agreed quite vell in soae but not all cases with observed values. (Auth.)

MODEL TYPE: paranetric

COHAHT: Could be adapted to evaluate iapacts on grassland ecosysteas.

$\langle 168\rangle$

Sinclair, T.R., and C.T. de tit 1976. Analysis of the carbon and nitrogen liaitations to sogbean yield. Agron. J. $68(2): 319-324$.

ABSTRACT: Soybeans are hypothesized to be "self-destructiven sioce they apparently need to translocate large amounts of aitrogen fron veget at ive tissues during seed-fill to sustain seed growth. To assess the possible sustain seed growth. To assess the possible limitations of this characteristic on soy nodel is developed which accounts for the avallability of nitrogen and photosynthate within the plant. The simuations show that the duration of seedfill and seed yield is clearly linited by the self-destructive characteristic. Increased availability of nitrogen ithin the plant is reguired for significant increases in soybean pields. possible alterations of the model required to iaic actual soybean seed growth are presented. (nuth.)

HODEL TYPE: eechanistic

COHART: hodel addresses a physiological question. The inpact of technology on seed yield could be partially evaluated but result would not be ralidated.

$\langle 169\rangle$

Sinclair, T.R., a nd E.R. Lewon, 1974 . Penetration of photosynthetically active radiation. Agrod. J. 66:201-205.

ABSTRACT: The penetration and aistribution of light in lesf oanopies are essential data to understanding the photosynthetic productivity of a crop. Light sensors which aeasure photos ynthet lcally active radiation were constructed and traversed through the leaf canopies of six types of com (2El MAYS L.) to observe radiation penetration. Onder clear sky conditions two ajor irradiance levels vere observed in the corn canopies. one irradiance level uas slightly less than the total radiation above the crop and represented the occurrence of sunflecks penetrating into the canopy. The second irradiance level vas uuch less than the first and ras compr is ed of sky radiation and radiation scattered by leaves. However, a decrease in the atount of direct solar radiation by either a orercast sky or a lov sun angle cesulted in a single, broad-band irradiance level. The data on sunfleck penetration also provided a basis for testing two physical oodeis of light penetration in leaf canopies. Data fros corn planted in a anfort, hexagonal pattern was in good

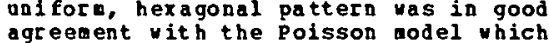
assuces a randow leaf distribution. Hovever, the Markor chain codel which introduces a frequency gap paraseter, lauba, to account for nonunifora leaf distribution vas required to obtain good agreesent with data recorded in the canopy of corn planted in rous $76 \mathrm{~cm}$ apart. This as especially true for the top part of the row-planted corn where sall, 


\section{APPENDIX A \\ Agricultural Models (continued)}

〈169> CONT.

short leaves resulted in large gaps for radiation penetration. The Markov nodel vould bo necessary, for instance, to deteruine the penetration of photosynthetically active radiation to the leaves in the oiddle of the canopy. Nevertheless, the pcisson nodel gave good agreewent with the neasured values for radiation intercepted by the entire canopy of the rou-planted crop. (luth.)

IODEL TYPE: paranetric

CCMnEN T: iseful alternative representation of liqht dissipation in a crop to the Bouguer-Lanbert law.

$\langle 170\rangle$

Spedding, C. R. Outlook Agric. $6: 242-247$

ABSTRACT: The definition of a particular agricultural ecospstem is inherentip difficult. partly because of the cosplexity of even the simplest system and partiy hecause cf the diffuse character of its periphery. Nevertheless, the general videspread acceptance in scientific circles. This is fortunate. as an understanding of the concept is indispensable in any consideration of the rcle of agriculture in the econoay of this fragile verld of ours. (Auth.) MODEL TYP: ccnceptual

COHAN $T$ : Outlines a systems analysis vieupoint of agricultural ecosysteas.

$\langle 171\rangle$

Splinter, R.E. 1974. Kodelling of plant growth for yield prediction. Mgric. Meteorol, $94: 243-253$

A ESTRACT: A corngrovth model is presented which requires three basic input parameters: average daily light intensity (1y), average diily teucerature (deg. C) and soi dasistance block reading (ohm). Comparison with field weasurements taken during the ith field measurements taken during the al though the ret season did not allor a test al the soil noisture component of the wodel. of the soi

MODEL TYPE: paräetric

Conas m: Hodel is tuned for Nebraska conditions and could be adapted for assessuent.

$\langle 172\rangle$

Stevens, T.A., and T.Y. Hazelton. 1976. Sulfur dioxide pollution and crop damage in the four corners region: A simulation analysis. Aqric. Pre. Sta. Bull. 647.

A BSTRAC?: A simulation codel was developed to forecast the impact of sulfur dioxide collution upon crop yields in the Pour Corners regicn. Alfalfa, which is extremely sensitive to sulfur dioxide, and winter wheat, which is less susceptible, were selected for analysis. Impacts vere avaluated by jialuting the relationship between the concentration of sulfurdioxide. the duration of exposure, leaf a rea, and yield. Three policy 10pilcations were comparison of monitored sulfur dioxide comparison of monitored sulfur dioxide were calculated to produce crop danage indicates that economic losses are probably indicates that econodic losses are probably not occurring as a result of sulfur second. it vas concluded that the existing anbient air quality standaras for 3 and 24 hours are sufficient to prevent danage to agricultural crops. Third, since aqricultural crops can be damaged by a short-tera exposure to sulfur dioxide, it is recomonded that federal and state governments consider the establishment of a one-hour sulfur dioxide air quality standard of 1.18 ppu or less. Purther research is reconmended to evaluate the possible synergistic effect of sulfur dioxide. nitrogen oxides, and other atuospheric pollutants. (kuth.)

KODEL TYPE: parametric

Connent: The model is relatively siaple and could be applied in other assessment situations.

(173)

Stewart, D.M., and E.R. Lewon. 1969. The energr budget at the earth's surface: $A$ siaulation of net photosynthesis of field corn. Research and Developaent Technical peport ECOH 2-68 1-6, 0.S. Army Blectronics Cóäand Atoospheric Sciences Lab., Fort Huachuca, $M$. MODEL TYPE: echanistic

ConghT: report provides an extensive overview of the soll-plant-atwosphere model (SPA H) that has been used extensively in agricultural odeling research. Model can be adapted for assessent of technology inpacts.

〈174>

rakakura, T., J. Goudriaan, and $\$$. Louverse. 1975. A behaviour nodel to simulate stonatal resiscance. Agric. neteorol. 15:393-404.

ABSTRACT: The purpose of the present study is to ake a behaviour odel wich night have a different structure fron the real systea but acts in the sase vay as the real systen does in the region considered. In the present model, the basic rorking hypotheses are a functional relationshlp between stonatal resistance and internal co (2) concentration and an effect of leaf teperature on internal resistance. It is found that stoatal resistance in the model responds to changes 1a light, external co (2) concentration and leaf temperature in a way which is experinentaliy confiraed. At the present stage of work on plant growth siaulation. the sodel way be good enough to account for the rather conplicated interactions that govern stonatal woveaent. al though some clear phenowena cannot be explained. (Auth.) novel Tre: mechanistic

ConnENT: This oodel can be included in wore compehensive plants nodels. Impacts on stomatal behaviour could be evaluated.

$\langle 175\rangle$

Takani. S., and C.H.H. Van Bavel. 1975 Nuperical experinents on the influence of co(2) release at ground level on crop assinflation and water use. Agric neteorol. 15: 19 3-203.

ABSTRACT: A godel to sinulate the effect of increased carbon dioxide levels on the gas exchange by a crop canopy was developed. The distribution of carbon dioxide in the canopy released frou a ground level area source, was calculated by a sothod reported elsewhere. In this submodel, the wind speed in the crop surface boudary layer, the $c O(2)$ concentration at the uprind edge of the release area, the $C O(2)$ release rate, and the aerodynanic canopy paraneters (crop height. aerodyauic canopy paraneters (crop height, vere the inputs. The radiant energy distribution inside the canopy vas conputed by a nodified Duncan-stevart subadel. using by a modified Duncan-stewart subaodel. osing the outputs of the subwodels and the air temperature. deupoint and effective soil water potential as inputs, a leaf gas and energy exchange subrodel calculated $C O(2)$ and vater vapor fluxes for each leaf layer, each characterized by physiological parameters that vere assumed constant with height. The 


\section{APPENDIX A \\ Agricultural Models (continued)}

〈175> con?

gas exchange of two sorghua canoples vas calculated by the proposed oodel for a crop grow th in central Texas. The efficiency of Co (2) enrichnent (the increase in the $C O(2)$ assiailation rate divided by the $C O(2)$ relea se ratel vas signiflcant only at a high re lease rate) was signiflcant only at a high efficlency of $13 x$ was predicted for a sparse and rough canopy at a global irradiance of about $1.000 \mathrm{~W} / \mathrm{a} * 2$ and at a ind speed of 0.5 a/sec. It was $16 \times$ for a dense and saooth canopy. The co(2) concentration half way in to the denser canopy was $3.6 \mathrm{~g} / \mathrm{a} * 3(1,997 \mathrm{Ppo})$ higher than the anblent level, at a yind speed of $0.5 \mathrm{a} / \mathrm{sec}$ at 2 a height, for release rate of $0.01 \mathrm{~g} / \mathrm{a*} 2 / \mathrm{sec}(360$

$\mathrm{kg} / \mathrm{ha} / \mathrm{h})$. Then $\mathrm{CO}(2)$ was continuously released in a sparse and rough canopy during a cals (average vind speed of $1.2 \mathrm{a} / \mathrm{sec}$ ) and clpar ing at rate of $36 \mathrm{~g} / \mathrm{a*} 2 / \mathrm{h}$, the co(2) clent ancentration at the crop height vas

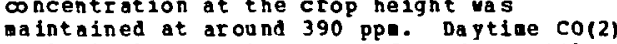
assicilation was increased froa $64 \mathrm{~g} / \mathrm{a} * 2$ without release to $80 \mathrm{~g} / \mathrm{a} * 2$ with release. The efficiency in this case vas ax. and vould have been $5 \%$ for a dense and swooth canopy. The daily vater use efficiency (crop assiailation divided by the crop water usel was enhanced froa 0.78 to 1. 1x. The results indicate that the proposed nodel is useful to evaluate the possibilities of $c 0(2)$ enrichnent in field crops in teras of crop $c O(2)$ assiailation and vater use under steady st ate conditions. (Auth.)

MODI TYP : echanistic

ccrsen T: Could be used to evaluate elevated at aospheric $\infty(2)$ levels in agricultura 1 crops.

$\langle 176\rangle$

Taylor, F. H.., and B. Klepper. 1975, Nater uptake by cotton root systens: An examination of assueptions in the single root model. Soil Sc1. 120:57-67.

ABSTRACT: Sereral athenatical nodels have been de veloped to describe vater uptake by plant root systeas. These nodels usualiy incorporate one cr ore of the assuaptions incorporate one cr core of the assuapt that water is proportional to rooting density, to soll hydraulic conduct ivity, and coot surface and that. In hulk soll aiduag between two adjacent roots. An experineat was cond ucted with cotton (GOSSYPI on HI RSOTOn) at the Auburn chizotron to test the validity of these three assunptions. Soil water potential, soil hydraulic conductivity. vater uotake, and rooting density dere asured or estiated as functions of 5011 depth and tine. Average plant water potential for a water extraction period was potential for a water extraction per estiuated froa pressure chamer and continuous sted diantion that water uptake is proportiona 1 to rooting density was valid. However, there appeared to te a large resistance in the path wa fros root epiderais to root xylea. The other tro assunptions aust be nodified to include this resistance. Therefore, vater uptake vas proportional to the vater potential difference between root xylea and bulk soil and to the hydraulic conductipity of the coabined soll-root pathway. There was no depth-cf-roots effect on the validity of these relationships. (Auth.)

MODEL TYOE: mechanistic

CCAnENT: Physiological research wodel and

un like $1_{y}$ to be useful for assessment needs.

$\langle\uparrow 77\rangle$

Thornley. J.R.A. 1972. A balanced quantitative model for root: shoot $r$ atios in vegetative plants. Ann. Bot. 36:431-441.
ABSTRACT: The vegetative growth of a two-conponent plant consisting of root and shoot only is considered in terns of the transport and utilization of two required substrates, one providing carbon and the other providing nitrogen. The nodel prorides a quantitatire schere for eranining hor coot:shoot ratios depend a pon the specific activities of root and shoot and hence

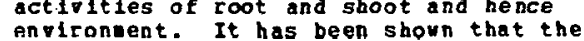
Anvironoent. It has been shown that the
total shoot activity is proportional to the total root activity in a plant undergoing steady-state grouth. (Auth,)

MODEI TYPE: paranetIic

COHHBHT: Physiological research nodel that coold be dapted to assessuent purposes.

$\langle 178\rangle$

Thornley. J.H.H. 1972. A aodel of a biochenlcal switch and its application to flover initlation. Ann. Bot. $36: 867-871$.

ABSTRACT: A siaple blochemicallp based nodel is constructed that exhibits suitching bebaviour vith two stable stead $y$ states. It aay be used for describing systens with alternative pathuays of developent. Its application to vegetative and flowering growth in plants is discussed in qualitative terss. (Aath.) HODEI TYPE: nechanistic

COHABH: Physlological research nodel not directly suitable for assessment.

<179>

Thornley, J.H. A. 1972. A nodel to describe the partitioning of photosynthate during vegetative plant grouth. Ann. Bot. 36: $419-430$.

ABSTRACT: An approach is described to the problea of odelling quantitativelp the partitioning of photosynthate during vegetative plant grouth. Two plant processes are laportant in the scheme: the first of these is the utilization of substrate for growth and how this utilization depends apon substrate concentration, the second concerns the transport of substrate between different plant parts and hou this depends upon the substrate concentrations in the plant parts. in both cases siople phenonenological In both cases sieple phenoenological in reasonable accord with experiental dat in reasonable accord with exper and with ore basic theoretical considerations. The nodel is able to describe soue of the features of steady-state regetative plant growth in a nataral anner. The liditations of the present formulation are considered. and the implications of this type of approach for whole-plant models are discussed. (Auth.)

HODEI TPPB: gechanistic

COHART: Physiological research model that has been used in whole plant growth codels. todel could be adapted for assessment studies.

(180)

Thornley. J.H. 197 . 1974. Light fluctuations and photosynthesis. Ann. Bot. 38:363-373.

ABSTRACT: The effects of fluctuating light on photosynthesis are exandned. A simple odel of leaf photosynthesis is used so that the analysis can be presented in explicit teras, the tiae-dependent problen is solved, and the response of photosynthesis to step changes in light-flux density is calculated. The presence of light fluctactions can cause a presence of light fluctaations can cav estiantes of photosynthesis; the relevant estiastes of photosynthesis; the relevant factors are the response tiae of the device used for aesuring light-flux density. the the leaf, and the steady-state light response curve vith the degree of non-linearity and the value of the light-flux density for 


\section{APPENDIX A \\ Agricultural Models (continued)}

$\langle 180\rangle$ CONT.

ma ximu photosynthesis being especially

inportant. Some general aethods for

estinating practically the effects of ligbt

fluctuations on photosynthesis are described. The use of the wethods of time-series analysis in such problems is discussed. (Auth.)

MODEL TYPE: mechanistic

COHMEN T: Physiological research model that could be adapted for assessaent applications.

$\langle 181\rangle$

Thornley, J.H. H. , and R.G. Hurd. 1974, An anaigs is of the grouth of young tonato plants in water culture at different light integrals and $c 0(2)$ concentrations. Ann. Bot. and $\operatorname{Co}(2) \mathrm{CO}$

ABSTRACT: The grouth anal ysis data of the preceding paper are exanined in terus of model. The model assumes that plant aaterial $c a n$ be divided into two categor ies: structure, and storage; it is further supposed that storage is the substrate for strurtinal grnuth, and that the rate nf structural growth depends on the a nount of storage substrate present. The model has three parameters, one of which relates to the source, and the other two characterize the since, and the other tro characterize description of the dat a considered. description of the data considered, a given temperature, the ma jor effect of the treatments vas on net assiailation ra te: the changes observed in relative grouth $r$ ate and leaf area ratic were then a result of the al tered net assiailation rate. It also sugaests that, over the range of environaents considered, the relative grovth rate cannot be ascribed to source or sink alone, but both are inportant determinants of growth. (Auth.) MODEl. TYPE: paratnetric

ccmanr: grovth analysis nodel that could be applied to greenhouse crop iapacts of tochnology.

$\langle 182\rangle$

Thornt hraite, C.X. . J.R. Mather, and J.R. Nakamura. 1960. Movenent of radiostrontium in soils. Science 131:1015-1019.

GONEI TYRP: paramotric

c canery: Could be applied to pollutant leaching assessuents in aqricultural soils although mo re mechanistic nodels are now available.

$\langle 183\rangle$

T Jepkena, J.D.. and C.S. Yocus. 1973. Re spiration and oxygen transport in soybean nodules. Planta (Berl.) 115:59-72.

ABSTRACT: The respiration $r$ ate of individual sophean (GLYCINE Max Merr.) nodules vas measured as a function of po (2) and te mperature. At 23 deg.: as the po(2) vas increased from 0.1 to 0.9 at $₫$, there was a linear incrcase in respiration rate. At 13 reg.. siailar results were obtained, except that there vas an abrupt sa turation of respiration at approxinately 0.5 ata po (2). ro spiration at approximately o. 5 a ta po When measurements vere made on the same nodule, the rate of increase in respiration deg. Additional results vere that $5 x$ co in the gas phase had no effect on respiration. except for a small decrease in the po (2) at which respirai on became saturated. Also. nodules still at tached to the sopbean root displayed the sane respiratory behavior as detached nodules. A model for oxygen transport in the nodule is presented which explains the se resul ts quantitatively. The ex sence of the model is that the respiration es sence of the morel is that the respiratio almost entirely deternined by the rate of oxygen diffusion to the respiratory enzynes. Eridence is given that the nodule cortex is the site of aluost all of the resistance to oxygen diffusion within the nodule. (Auth.) MODEI TYPE: wechanistic

COMKENT: This study ises the nodel described by Lon wen et al (1971) Planta 98: 195-220. Its adaptation to oxygen transport to dodules ay also be used for assessment al though the model is oriented to physiological research.

$\langle 184\rangle$

Torssell, B.R.R.. and A.O. Nicholls. 1976. A conparison betueen tro models for plant
conpetition. Aust. J. Rcol. 1:29-35.

ABSTRACT: The differential equation of de (1970) which predicts the grouth of plant species in wixtures from their yield-density response in onoultures is conpared with a silpler equation. This odel is also based on the yield-density response of species grown in aonocultures, but is static and predicts only the net result of plant conpetition during discrete tive perlods. nat a fros surgess fipe harqest.s in

jield-density experinents in monocultures of one grass and two legume species were fitted to both nodels and the relative reproductive rate and the relative replacement rate vere rate and the relative replace uent

predictions from our aodel agreed sore Predictions from our dodel agreed are
closely with observations than predictions frow the de it oodel. It is concluded that our nodel deserves further attention in the studies of population dyanics in alxtures when the final outcone of conpetition is the ain interest. (Ruth.)

MODEL TYPE: parametric

COMBENT: Model could be adapted to evaluate technology iopacts on plant competition.

$\langle 185\rangle$

Iravis, J.R. 1974. A model for predicting the redistribution of particulate contaninants froa soll surfaces. In: Engelaann. R.J.: schmel. G.A. (eds.), Atmosphere-surface exchange of particulate and gaseous pollutants. PP. 906-944. ERDA Syap. serles 38. Technical Inforuation Center, DOE. pashington, DC.

Astract: A rompliterized motel vas developed to describe the redistribution of vind-eroding soil-contaminant aixtures. Potentially nobile particulate contaninants can, in the first approximation, be assuned to be first approximation, be assuned to be in vhich they are distributed. $A$ grid net work characterizes important soil and net work characterizes important soil and surface conditions, and ass conserving control volumes are constructed on each cell and to surfaces of a control volune by a nodified bagnold-chepll horlzontal flux foraulation and modified Gillette vertical flux fortulation, respectively. The vertical esiseions, considered as pufes fron area sources, create at regular tine intervals a contaninant clood proportional to the suspendable ground concentration. These puffs diffuse dounuind under tipe-dependent puffs diffuse dounvind under time-depen conditions a intaining during the interval conditions, a intaining during the interval three-diuensional Gaussian distribution of
concentrations vith cloud volume. Hateria frow each puff is deposited in downwad cells, leading to the possibility of ang different flights from the se new sources. The usefulness of this predictive tool is denonstrated by calculations involving mixtures of particulate 238 Puo (2) in highly erodible soils under dust stora conditions. rine-dependent surface concentration and breathing zone exposure isopleths, evolving from sall containated area, show the 


\section{APPENDIX A Agricultural Models (continued)}

(185) CONT

potential hazard frou vind-eroding toxic materfals. (Auth.)

NODEL TYPE: mechanistic

CCMMENT: Model could be applied to evaluate al terial transport to and vithin agricultaral fields frce technoloqy sources.

〈1ค6)

Truestell, 1. H., and B. F. Jones. 1974. HATBQ, a conputer próras for calculating cheaical equilibria of natural waters. J. Res. 0.s. Geol. Survey 2: 233-248.

ABTRAT: The conputer progran, WATEO.

calculated the equilibriun distribution of inorganic aqueous species of major and inportant ainor eleaents in natural vaters using the chenical analysis and in situ a a surements of temperature, $p h$, and.redox potential. Pron this model, the states of reaction of the water vith solid and gaseous phases a calculated. The reorly na mir. stabilities of aqueous species, unerals, a da gases have been selected fIod careful gases have been selected froe careful data. The progran is vitten in PL-1 for IBy 36 computers. (Auth.)

MODEL TYPE: Pechanistic

C CHnEN T: A detailed nodel that could evaluate in pacts of tenperature, ph and redox potential changes on chenical equilibria of well vater and streans.

$\langle 187\rangle$

ran Ba vel, C.H.A. 1975. A behavioral equation for leaf carbon dioxide assinilation and a test of its validity. photosynthetica test of its
$9(2)=165-176$.

ABSTRAC?: A set of tro simple equations describes the foint effect of irradiance. anbient $C O(2)$ level, and leaf diffusion resistance upon the $\operatorname{Co(2)}$ flux density of $a$ leaf. The principal leaf paraseters are the maxiug assiailatory capacit $y$. the efficiency of radiant energy utilization or maxian photon pield, and the co(2) utilization efficioncy. The proposed oodel shows the "1 ouble saturation " ef fect of irradiance and Co (2) level, the co(2) efflux in the dark. and the significance of the $\mathrm{CO}(2)$ coapensation point for the efficiency of coapensation point for the efficiency de wonstrates that the leaf diffusion resistance is critical for the shape of ir radiance response curves. 111 leaf pa rameters can be obtained froa comon laboratory experiments. A test of the codel with g ouflovor loaf gavo sat ifactary agreesent tetween experioent and theory. The sunflover leaf paraneters vere calculated for a leaf teaperature of $25 \mathrm{deg}$. C. The aaxiaud assililatory capacity was $0.008 \mathrm{~g} / \mathrm{a*} 2 / \mathrm{s}$, the CD (2) otilization efficient 7.7 * * $3 / 9$ and the efficiency of radiant energy utilization $4.9 \mathrm{~g} / \mathrm{elngte}$. or a photon requirenent of 9 eingtein/mol. The proposed equations are primarily intended for ase in comprehensive aodels of plant and canopy behavior, and of productivity and water ase of olant commities. (huth.)

MODEL TYPE: aechanistic

c chineN T: Could be a dapted for assessnent purposes by inclusion in aore conprehensive plant wodelo.

$\langle 188\rangle$

Yan Bavel, C.H.H.. and J. Mheed. 1976. Dynanle st aulition of water depletion in the root zone.

ABSTRAC?: The joint effect of the distribution of the soll water potential and of the root ass in the crop root zone upon the uater up take by the crop is represented by a siaple equation. This expression is used to foin. layered crop canopy wodel for finding the evapotranspiration, as controlled by stoatal act ion and the veather. vith a hydraulic flow model for the root zone and the underlying soll. The cooplete adel is used for the calculation of the water extraction pattern and the changes, with tine, of other plant and soll processes. A simulation of a 20-day drying perlod is performed, using $5 / 360$ CskP. for a constant di ural veather. pattern, and for a fullg developed sorghu crop. The ror a fully developed sorghue crop. The results shoy that, af ter fey days of essentialiy constant water ase by the cropi notonic decline sets in that
attributable to the decrease in

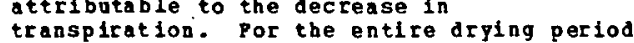
a substantial anount of vater - about $30 x$ of the total used - is contributed by upvard flow into the root zone froa the soil below. The results dewonstrate the difficulty of quantitative definition of concepts such as "fleld capacity", "uilting percentagen, and navailablen or "extractablen vater. (iuth.) MODEL TYPE: vechanistic

contint: could be used for assessnent in

conbination ith a crop evapotranspiration oodel.

$\langle 189\rangle$

Tan Bavel, C. H. A., and D.I. Hillel. 1976. calculating potential and actual evaporation fron a bare soil surface by simulation of concurrent flow of water and heat. Agric. Met eorol. 17:453-476.

ABSTRACT: Aunerical othod is described by which the instantaneous evaporation rate fron bare soil. regardless of its vetness, can be est isated frog standard veather data and the physical characteristics of the soil profile. physical chacracteristics of the calculate potential It is used to calculate potential evaporation from a surface energy balance whout the comonly used approx a thons. the soll surface elittance ay vary enough vith soll water content so as to ake the concept of potential evaporation anbiguous. Fron a practical vievpoint, hovever, these differences in the evaporation rate froa vet surface are not large enough to invalidate the siapler coabination or energy bal ance for un las, in hlch the surface albedo and roughness a the only non-clisatic and roughness are the only non-clieatic parameters. The weth od is particularly
use ful in sloulat 1 ing the evaporation process use ful in sludating the evaporation process the eristence of separate potential and falling rate stages of evaporation. but not that of a third. Constant rate stage. $A$ rapid increase of the diurnal apilitude of the surface tewperature is the clearest indicator of the transition between the tvo stages. (A uth.)

MODEL TYPE: Dechanistic

Connert: Could be used for assessaent of inacts on soll eraporation.

$\langle 190\rangle$

van Keulen, H., and C.G.E.H. van Beek. 1971. water oreent in layered solls - A sieulation nodel. Netb.J. Agric. Sci. 19: 138-153.

ABSTRACT: A sinulation odel for infiltration of vater in layered solls. vilten in CSMP (Continuous syster hodeling prograa). Is described. The 1 nfluence of the occurrence of a conpacted la yer or a loosened topsoll on the infiltration behavior is checked. It is concluded that this behavior can be predicted concluded that this behavior can be predict if soll parameters are avaliable. In an appendix special attention is paid to the coupartments in which the soll is divided and the necessary areraging procedure. it last 


\section{APPENDIX A \\ Agricultural Models (continued)}

(190) CONT.

the magnitude of the time steps is discussed. (Auth.)

MODEL TYPE: Eechanistic

C CMMENT: Could be used to evaluate infiltration and soil surface effects on vater flov.

$\langle 191\rangle$

Verhagen. A.M.H., J. H. Wilson, and E.J. Britten. 1963. plant production in relation to foliage illo

ABSIRACT: The intensity of light received by plants can be specified in teras of its extinction ith depth in the foliage. va rious light-extinction functions ar introduced to specify the light received by plants vith different patterns of foliage developuent ( $\nabla$ iz. standard exponential, best exponential, and ideall. The inplications of theso extinction functions are discussed and the production associated with each foliage the production associated as a function of leaf area ty pe is studied as a function of leaf area index. LAI (the ratio of leaf a rea to g area). The concepts of optiou LAI a nd cailing IAI are considered in relation to to what has previously been thought. a foliage in which the bottom leaves are at compensaticn point is not necessarily at optimum IAI. It also becowes possible to reconcile conflicting views on the

relationship betveen optimu LAI and ceiling LAI. (Auth.)

MODEL TYPR: wechanistic

c cmancr: Has limited use in assessaent since other plant aodels are available with more orprehensive algorithas.

$\langle 192\rangle$

Vaggoner, P.E. 1969. Environmental manipulation for higher yields. In: R.C. Dinauer (ed.). Physiological Aspects of crop rield, pp. 34 3-373. Aa. Scc. Mgron., Madison, MI.

ABSTPACT: The effect of environmental ma ni pulation upon the photosynthesis and the pield of a crop canopy is explored by the use pield of a crop canopy is explored by the use of mathe matical nodels. These nodels or crop si mulators use logical rules for calcu photosynthesis but also vork in aany vays li he an aotual orop. The first or microli mate siaulator accepts neus of the veather arcue, the tenperature and huaidity of the air beneath the canopy, as vell as the canopy a rchitecture, stonat al resistance, absorption of radiation. and ventilation. Fr om these factors the simulator calculates and the leaves vithin the canopy. The second or photosynthesis siaulator accepts the or photosynthesis siaulator accepts the output of the first pl us the following
characteristics of the individual leaves: (1) photochenical facilitp and how it varies (1) Photochenical facilitr and ho concentration, (2) Dark respiration and hov it valies with temperature, (3) L1ght respiration and how it varies with temperature and light and (4) The physical resistances to the current of $c 0(2)$. The second simulator also accepts the Co(2) concentration above and belor the canopy and concentration above and belou the canopy and advected into the canopy at different levels. advected into the canopy at different calculates the co(2) concentrations in the iI and the chotosynthesis in the leaves of the canopy. Manipulating the leaf pores or stomata can decrease evaporation, and the si mulators indicate that photosynthesis will be decreased relatively less. This is a different cutcome than fron a decrease in photochemical facility, which would decrease photosynthesis relatively aore than evaporation. Increasing the light either from above or below the canopy would increase assiablation nearly proportionally. Since great differences in ventilation have little effect upon assiollation, the conservation of vater by shelter extracts no hidden tax of decreased delivery of $C O(2)$ for photosynthesis. Naturaliy ventilated canopies are very porous. Hence, the recorery by photosynthesis of co(2) released fron dry ice or decay belou or within the canopy is inefficient. on the other hand, the general increase of $0.72 \mathrm{ppo}$ co (2) per year in the increase of $0.72 \mathrm{ppo}$ co (2) per yea
earth's a toos phere vill increase earth's at wosphere wil increase photosynthesis in efficient species and full
sunlight by $7 \%$ betueen now and the end of the sunlight by 7\% bet
century. (nuth.)

CODEL TIPE: Dechanistic

COnnENT: Physiological research model with flexibility to evaluate aicroclinate effects on plant grovth. Could be adapted to evaluate aspects of technology iopacts on crop grouth.

$\langle 193\rangle$

Maggoner, P.R., G.H. Furnival, and N.E. Reifsnyder. 1969. Siaulation of the - icroclinate in a forest. Porest sci. $15: 37-45$.

ABSTRACT: A nodel of the energy exchange vithin a canopy of leaves is presented in terms of three sets of equations. The suns of radiant. sensible, and latent heat exchange in several strata of the canopy are set equal to zero. Next, the potentials for the exchange of latent and sensible heat are exchange of latent and sensible heat pinally, the difference in potential betreen Pinally, the difference in potential betreen adjacont strata are rolated to the diffusive boundary layer, and the stomata, and to the fluxes of latent and sensible heat. This systel of simultaneous linear equations is solved algebraically for the exchange of 1 atent and sensible heat by each stratun of the canopy, for the leaf tenperature of these strata, for the exchange of latent and sensible heat by the soil. and for the storage of heat vithin the soil. The tenperature and hylidity above and belov the teaperature and hugidity above and below the canopy, the atsorption of radiation

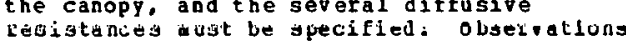
of the exchange of energy and the aicrocliate vithin a pine canopy are ninicked by the model. Nine strate are demonstrated to be an adequate number. calculations vith the model explain the effect of stomatal changes upon the evaporation froa a forest. (Ruth.)

MODEL TYPE: nechanist ic

to evaluate effects of icrocliate changes on crop evaporation in the vicinity of industrial plants.

$\langle 194\rangle$

Waggoner, P.E.. a nd W. E. Kelfsnyder. 1968. Sioulation of the temperature, hunidity and eyaporation profiles in a leaf canopr. J. Appi. Heteorol. 7:400-409.

ABSTRACT: The proposed model synthesizes profiles of teaperature. hunidity and evaporation in a canopy of leaves froa evaporation in a canopy of leaves eron meteorological conditions at canopy top; the teaper ature and humidity at the soil surface, frou a leat dinension, fros th vertical distribution of leaf area and
stonatal resistance, and from observations or extinction coefficients for ventilation and radiation uithin the canopy under steady-state conditions. The exchange of sensible and latent heat in a canopy stratuo is required to be equal to the absorption of radiation by the leaves in that stratud. 


\section{APPENDIX A \\ Agricultural Models (continued)}

(194) CONT.

Purther, the difference betueen strata in

their potential for sensible and latent heat exchange is related both to leaf te mperature and to the fluxes and diffusive resistances between the leares. Leaf temperatures, evaporaticn and sensible heat exchange, and air temperatures vithin the canopy that neet these reguirenents vere calculated by successive approxination. The dicroclinate and evaooration ce a red clover and of a barley canopy vere simulated, and changes in evaporaticn fron a canopy folloving aoderate changes in stomatal resistance vere explained by the mcdel. (Auth.)

MODEL TRP :

COMA EN ?: Could be used in assessuent of technology effects on canopy aicroclimate.

$\langle 195\rangle$

Yalker, H... T.R. Feck, and S.G. Carmer. 1969. Relationship bet veen soybean yields and leaf le vels of 10 eleaents deter ined uith different regression nodels. Agron. J.

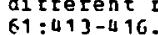

AESTRACT: Soptean leaf samples and yields ve re obtained from experimental plots receiving $v$ rying levels of $P$ and $k$. Pields vere regressed on a quadratic polynonial uth leaf
levels of $p$ and $g$ as variables. This regression had an $R * * 2$ of 0.495 . Yields were regressed on a second quadratic polynonial with leaf levels of $N, P, R, C a, M g, B, C u$ $P_{2}$, $n n$, and $2 n$ as rariables. With the st epv ise regression frocedure used for fitting the model, 22 linear and second orler teras we fe fitted to the data. This regression had an $R * 2$ of 0.813 . The aditional variation accounted for by the second regression was statistically significant. Other polynoalal regressions significant. Other polynoalal regression
ve re fitted to the data using $r$ atios of elements as independent variables, but none vere supericr to the quadratic polynouial in teros of $\mathrm{R} * 2$ values. (Auth.)

MODEL PYPE: statistical

COAHENT: Not readily adapted to assessaent of tehenology inpacts.

$\langle 196\rangle$

arrick. A.N. 1970. A mathematical solution to a hillside seepage problea. Soil sci. Soc. AII. $P$ roc $34: 849-853$

ASTPACT: A solution is presented for a two-dinensional hillside seepage problew. The soil is assumer to be water-saturated to the soil surface vhere the soil water is at at mospheric pressure. Seepage occurs into the flow mediun along the uoper part and out al ong the lover part of the sloping soil surface. The flcu nediug is infinitely deep and bounded laterally by vertical st reamines. Conformal transformations are st reamines. Conforal transformations are used to find the hidraulic head and functions. Although the solution is analytic, a complex integral wust be Qvaluated numerically for application. se epage velocities, infiltration angles, and volute of flcu as a function of slope. (Auth.)

MCDEL TYPE: mechanistic

C CAHEN T. Potentially useful in assessment abplications involving soil vater drainage.

$\langle 197\rangle$

Mierenga, P.J.. and C.T. de Mit. 1970. si uulaticn of heat transfer in soils. Soil Si 1. SoC. Ala. Ptoc. 34:845-848.

ABSTRACT: A computer model was developed to predict the tenperature fluctuation in subsoil frca the tomperature pariation at the soil surface, taking into account changes in the apparent thermal conductivity with depth belou soil surface and soll temperature. The model makes use of $5 / 360$ cs MP, a recentiy developed simulation language for digital
conputers. Predicted soil temperatures ver compared with soil temperatures observed at 2, 10, 15, 25, 30, and $75 \mathrm{~cm}$ below the surface of bare field profiles, before and after irrigation with 13.4 ca water. In vet soil observed and predicted tenperatures vere in close agreement. In dry soil significant differences ere observed betueen peasured and predicted soil temperatures during part of the day. The increase in apparent theraal of the day. The increase in apparent ther negative effect on the magnitude of the difference between observed and predicted ralues in the dry soil. Agreement was found between soil heat flux density values predicted froo the model and calculated with the temperature integral aethod. Ose of a digilal slmulation language can save considerable programaing time, and can be applied to wovement of vater and gases in soll profiles. (Auth.) SOIl profiles. (Auth
MODEL TYPE: wechanistic

conaris: Could be used in waste heat iapact ass essment.

<198>

Woo. K. B., L. Boersma, and L.N. Stone. 1966. Dynanic sinulation model of the transpiration process. Water Resour. Res. $2(9): 85-97$

ABSTRAC $\mathrm{m}$ : Plant life processes are related in a couplex vay to the balance between the water dea and of the atmosphere and the avajlability of vater to the plant root. An exploration of the dynaic status of vater in the plant is the dynaric status of vater in the plant integrated analysis of the dynamic systea of vatel wovenent through the soil-plant-at nosphere continuum, a siaulation wodel of the transpiration process is presented. Van den Honert suggested the use of oha's law describing uater flow into. through, and out of plants. In the present study. this hypothesis has been expanded to include an analogous storage factor to deal with the dynanic flow of vater in the plant. A set of differential equations and transfer functions is expressed in teras of trans suction variables. The dynaic description of the water status in the plant is completed of the water status in the plant is complet function of both the transpiration rate and the soil-yater condition. The dynamic system gain is realized by a method similar to corbin's sethod of a cosputer-controlled adaptive control systea. The entire systen is then siaulated on an analog computer: 1ts consideration of various environmental effects. (Auth.)

MODEl TYPE: (Auth.)

conurnT: Could be used in assessment. Hoverer. equivalent digital models are available.

$\langle 199\rangle$

Hoo, R.B., L.H. Stone, and L. Boersma. 1966. A conceptual model of stoatal control aechan isas. Qat er Resour. Res. 2:71-84.

ABSTRACT: The stomata of plant leaves constitute a wain regulating systen of the transpiration process. Biologists have suggested a turqor mechanism to explain stomatal moveant. The wechanisu to explain stomatal moveant. The functions of the aechanisa are quantitatively
described by an osnotic water transfec theory and/or the active vater transfer theory in and/or the active water transfer theory in the guard cells. Based on the active wat stowatal wovement under various conditions of $H(2) 0, C O(2)$, and light, a conceptual model of the stomat al control wechanisw is proposed. Transfer functions of the 


\section{APPENDIX A}

\section{Agricultural Models (continued)}

<199> CONT.

mechanisms characterizing the changes in turgor pressure have been derived. The entire spstew has been organized by the application of adaptive control systen theory log conpute The dynaic characteristics have been investigated vith consideration of rarious environiental conditions. (Auth.)

mone I TPP.

COHAEN: Research wodel with too wuch detail for as sessment purposes.

$\langle 20 n\rangle$

Yang, S.J., and E. de Jong. 197\%. Effect of soil vatei potential and bulk density on water uptake patterns and resistance to flou of vater in wheat plants. Can.J. Soil Sci. of vater in

ABSTRACT: Rater uptake patterns of vheat plants were studied in a growth chaber by using tuo soils packed to three different buik

densities. The resistances to water dovewent in the soil and in the plant vere calculated fron the nathenatical model for water uptake published in the literature. Then the capillary potential of the solls was near $-1 / 3$ bar, Withdraval of water by plants was relativeip sall and oost of the vater vas taken from the top $25 \mathrm{ca}$ of the soll colunn. As soil water potential decreased, water uptake increased progressively tovard the uptake increased progressively tovard the lover part of the soll coluan. The resistance to vater avenent in the plant increased froe the top to the botto of the root spsten and increased $v$ ith increasing bulk density of the soils. Por vet solls. unrealistic values vere obtained vich could be due to the fact that the interaction between aeration and coisture nptake is not taken into account in the theoretical equations for soisture uptake. (Auth.) MODEL TYPE: wechanistic

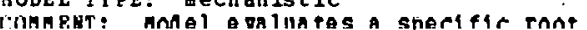
chafacteristic and is not suitable for assessaent. 
APPENDIX - B

AUTHOR INOEX 


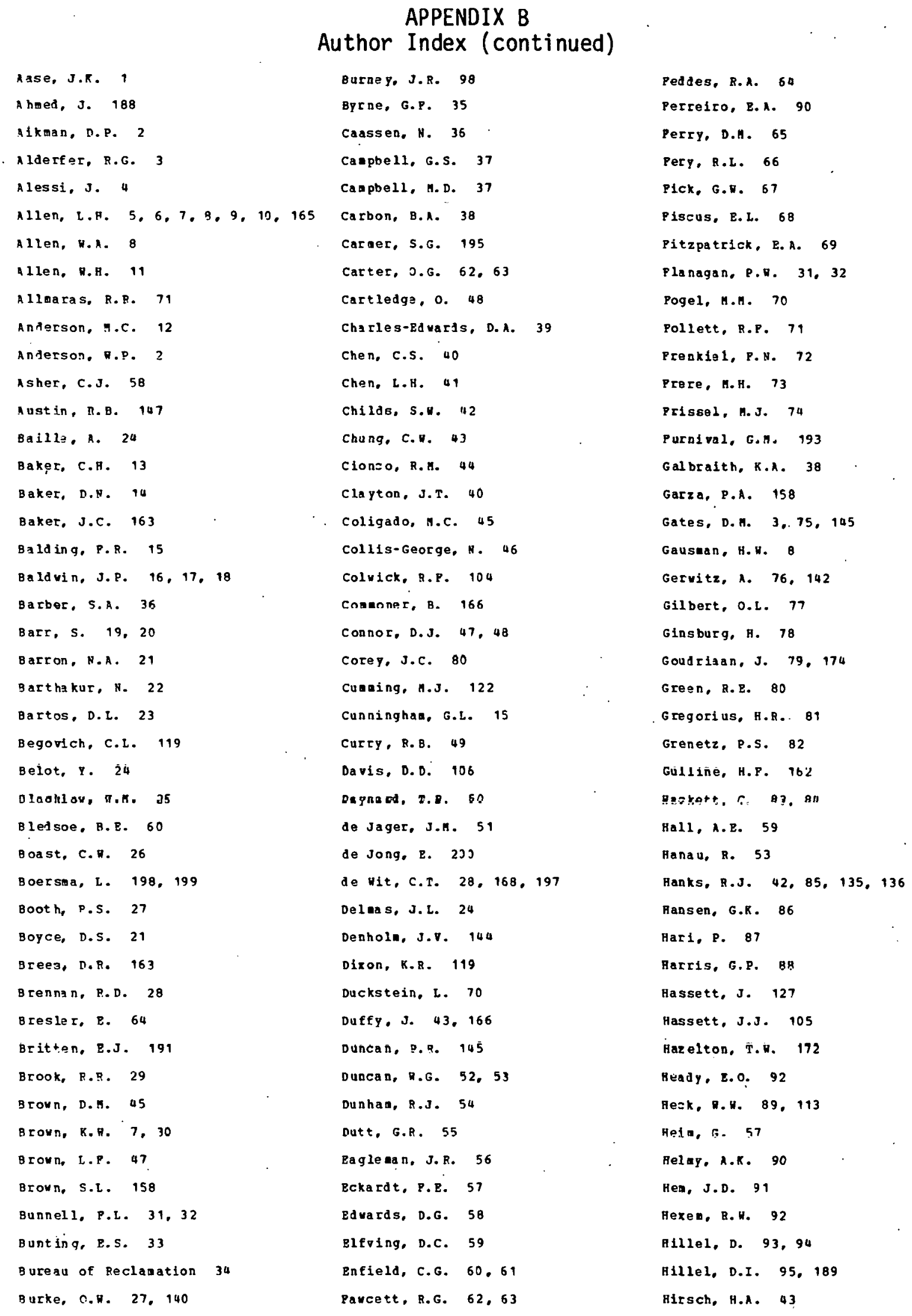




\section{APPENDIX B \\ Author Index (continued)}

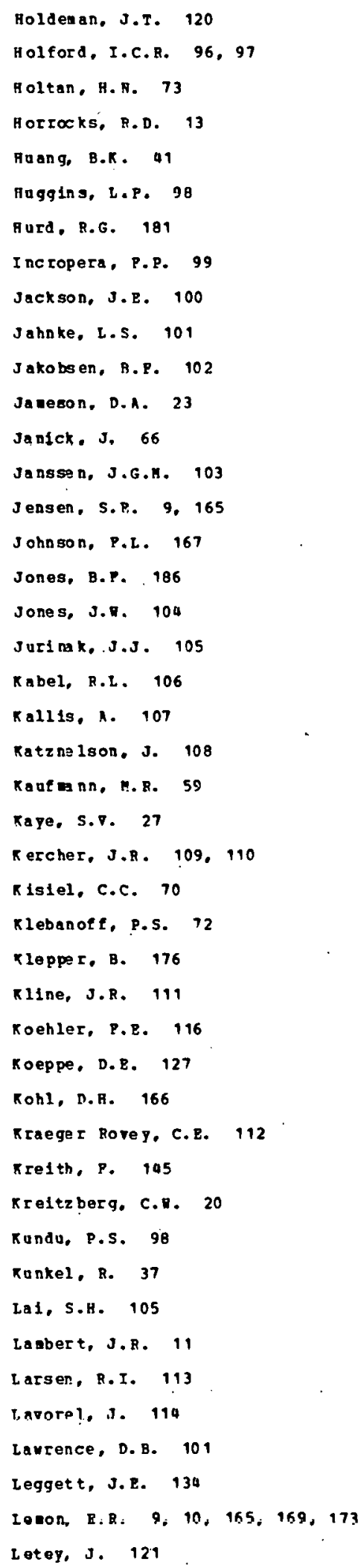

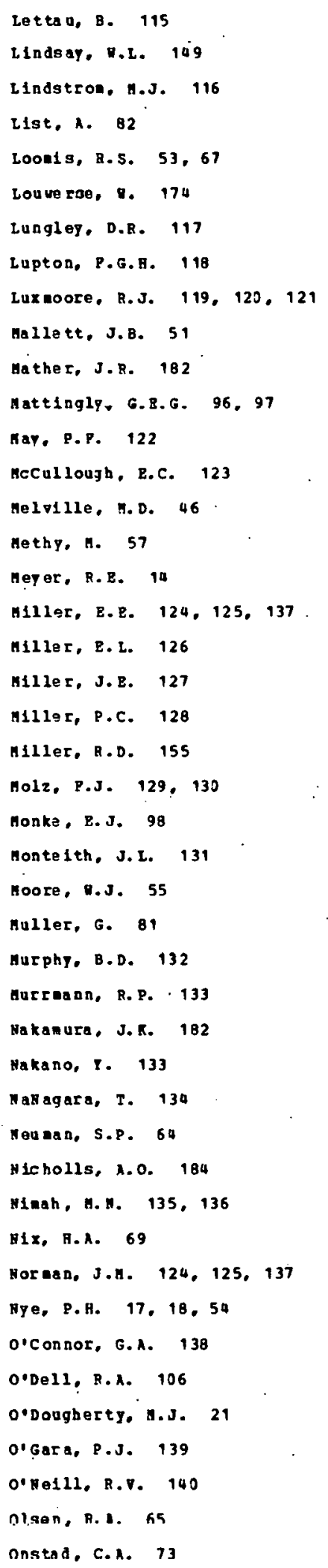

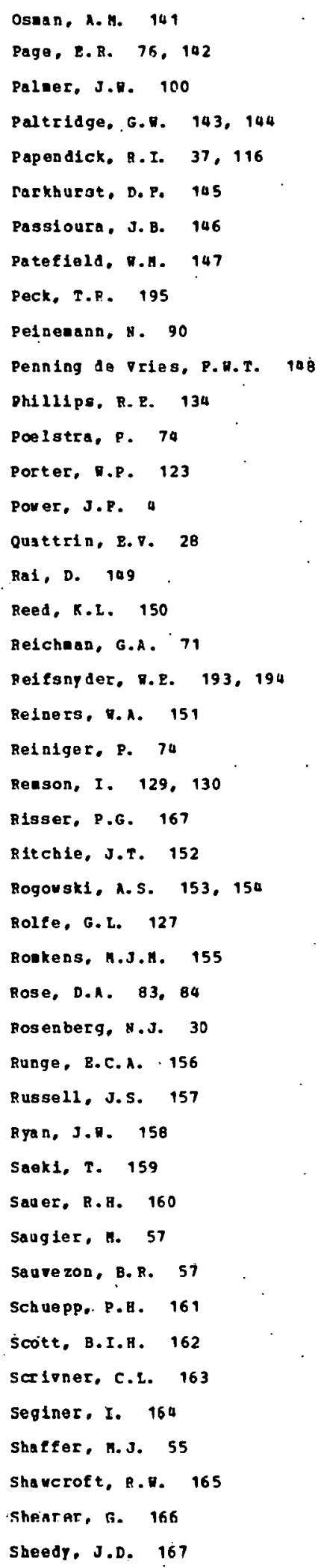


Shen, D.C. 61

Shrader. D. D. 126

Shugart. H. R. 110

sidd ova y. P. H. 1

Sinclair. '.P. 168, 169

Spedding, C.R.R. 170

Splinter, R.E. 49, 171

sposito, 7.A. 92

Stevens, T.H. 172

Stevart, D. 1. 10, 165, 173

Stolzy, J.I. 120

Stolzp, L.H. 121

stone, L.8. 198, 199

Stoner, W. A. 128

Taheri. H. 106

Tait, D.E.N. 31, 32

Takakura, T. 174

Taka toi . 5. 175

Talpaz, R. 93,94, 95

Tanner, C. B. 137

Taglor, ห. H. 176

Thornley, J.R. 1. 39, 177, 178 , 179. 980. 181

Thornthwaite, C. W. 182

Threadgill, E. D. 104

Ti11. A.R. 122

Iluyey. 0.T. 69

Tinker, P, B, 17, 19

T Jepke a. J. D. 183

Tcouing, H. 107

Torsse 11, B. H.R. 184

Ttrạtis, J.H. 185

TIlica. ค. J. 47

Trueslell, A.H. 186

van bavel, C.H. 万. 95, 175, 187. 188,189

van Beek, C.G.E. A. 94, 190

van Cleve. R. 31

van Genuchten, H.T. 138

van koulen, н. 93, 190

vechagen, A.H. H. 199

waggoner, P.P. 79, 192, 193, 194

Halker, М. 195

Haring, P.н. 150

Harri=k. A. .. 196

Hedderburn, R. H. \&. 97
APPENDIX B

Author Index (continued)

Wheeler, G.L. 127

Dhite, K. D. 161

Wierenga, P.J. 138, 197

Milllaes, H. A. 28, 53, 67

Milson, J.H. 191

No0, K.B. 198, 199

Rright. J.R. 1

lang, S.J. 200

Yocus, C.S. 183 
APPENDIX C

KEWWRD INDEX 


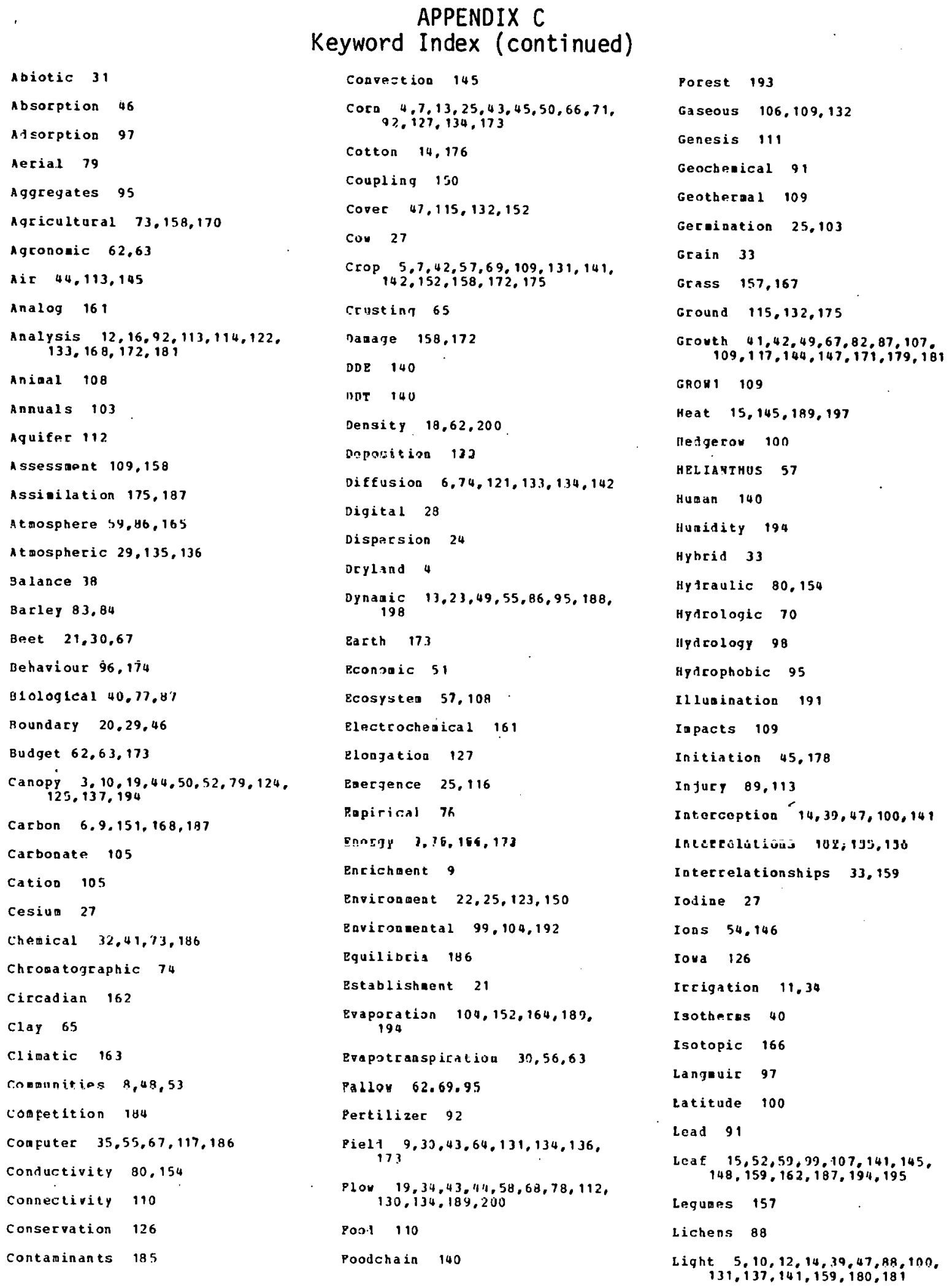




\section{APPENDIX C \\ Keyword Index (continued)}

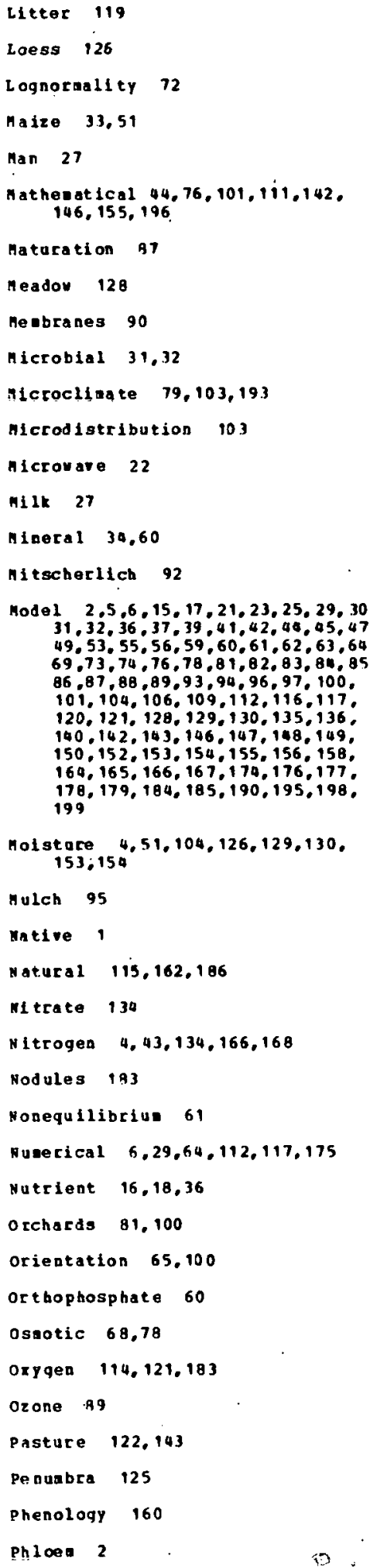

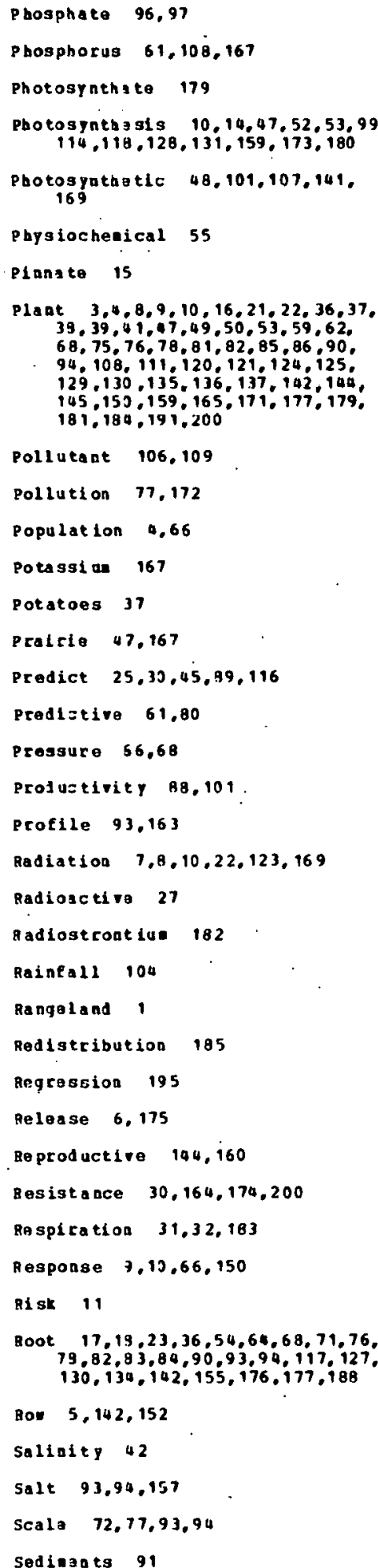

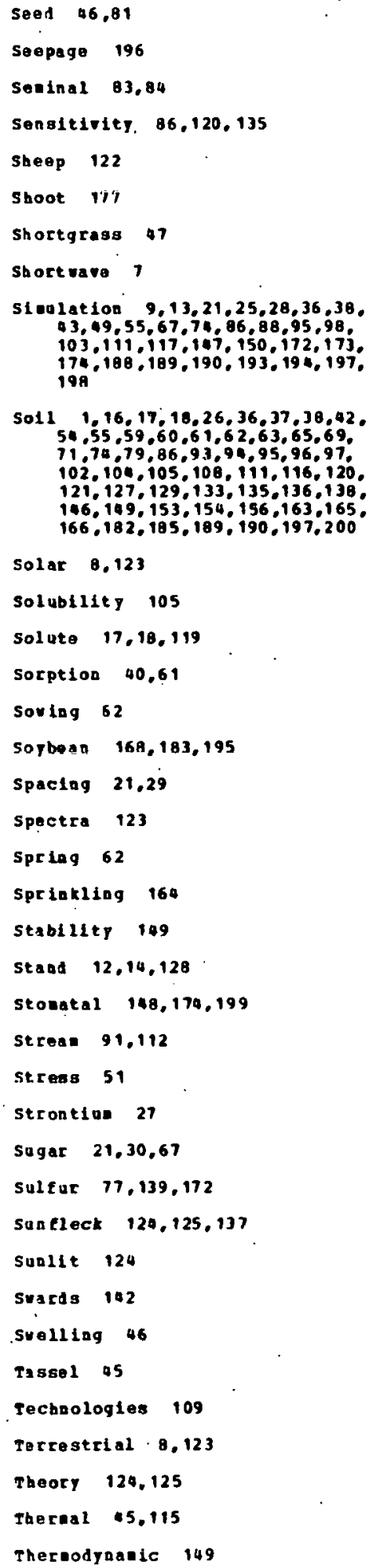




\section{APPENDIX C \\ Keyword Index (continued)}

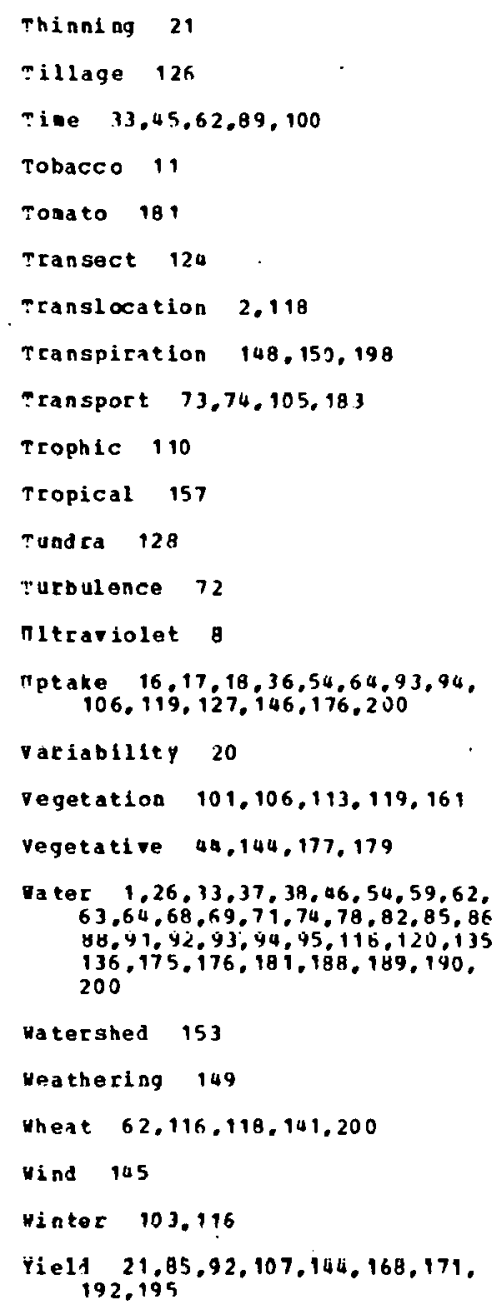


ORNL/TM-6694

INTERNAL DISTRIBUTION

1-8. S. I. Auerbach

9. R. L. Burgess

10. K. E. Cowser

11. R. B. Craig

12. C. T. Garten

13. W. F. Harr is

14. S. G. Hildebrand

15. F. 0. Hoffman

16. D. D. Huff

17. S. V. Kaye

18. J. M. Kl opatek

19-24. R. J. Luxmoore

25. S. B. McLaughlin

26. V. G. Myers

27. J. S. 0lson

28. R. V. O'Neill
29. P. T. Owen

30-35. D. C. Parzyck

36. P. S. Rohwer

37-43. E. M. Rupp

44. D. S. Shriner

45. R. Shor

46. T. Tamura

47. J. A. Watts

48. J. P. Witherspoon

49. ESD Library

50. Biology Library

51-52. Central Research Library

53-54. Laboratory Records Department

55. Laboratory Records, ORNL-RC

56. ORNL Patent Office

57. ORNL Y-12 Technical Library

EXTERNAL DISTRIBUTION

58. Office of Assistant Manager, Energy Research and Development, DOE/ORO

59. L. R. Anspaugh, Lawrence Livermore Laboratory, P.0. Box 808, Livermore, CA 94550

60. D. A. Baker, Battelle-Pac if ic Northwest Laboratories, P.0. Box 999 , Richland, WA 99352

61. R. H. Ball, Division of Environmental Impacts, Office of Technology Impacts, Department of Energy, Washington, DC 20545

62. R. W. Brocksen, Electric Power Research Institute, P. O. Box 10412, Palo Alto, CA 94304

63. C. F. Cooper, Center for Regional Environmental Studies, Cal ifornia State University, 5402 College Avenue, San Diego, CA 92115

64. William J. Coppoc, Texaco, Inc., P.0. Box 509, Beacon, NY 12508

65. T. V. Crawford, Savannah River Ecology Laboratory, Aiken, SC 29801

66. Roger C. Dahlman, Office of Health and Environmental Research, Department of Energy, Washington, DC 20545

67. Stanley N. Davis, Head, Department of Hydrology and Water Resources, University of Arizona, Tucson, AZ 85721

68. Ted Fowler, U.S. Environmental Protection Agency, Office of Radiation Programs AW-460, 401 M Street, S.W., Washington, DC 20460 
69. Robert M. Garrels, Department of Geological Sciences, Northwestern University, Evanston, IL 60201

70. N. R. Glass, Corvall is Environmental Research Laboratory, 200 S.W. 35th Street, Corvallis, OR 97330

71. A. J. Goldberg, Division of Technology Assessments, Office of Technology Impacts, Department of Energy, Washington, DC 20545

72. T. R. Harris, Division of Regional Assessments, Office of Technology Impacts, Department of Energy, Washington, DC 20545

73. Walter W. Heck, USDA-SEA-AR, Botany Department, North Carolina State University, Raleigh, NC 27650

74. Allen Hirsch, Office of Biological Services, Fish and Wildlife Service, Department of the Interior, Washington, DC 20240

75. J. C. Hock, Division of Regional Assessments, Office of Technology Impacts, Department of Energy, Washington, DC 20545

76. P. W. House, Office of Technology Impacts, Department of Energy, Washington, DC 20545

77. Jacob Kastner, Environmental Standards Branch, Directorate of Licensing, U.S. Nuclear Regulatory Commission, Washington, DC 20555

78. Arthur Katz, Office of Technology Impacts, Division of Regional Assessment, Department of Energy, Washington, DC 20545

79. R. N. Kickert, Department of Forestry and Resource Management, 145 Mulford Hall, Berkeley, CA 94720

80. George H. Lauff, Director, W. K. Kellogg Biological Station, Michigan State University, Hickory Corners, MI 49060

81. Simon A. Levin, Section of Ecology and Systematics, Bldg. No. 6, Langmuir Laboratory, Corne11 University, Ithaca, NY 11850

82. 0. L. Loucks, The Institute of Ecology, Butler University, Indianapolis, IN 46208

83. Paul J. Magno, Office of Radiation Programs, U.S. Environmental Protection Agency, Washington, DC 20460

84. John J. Magnuson, Laboratory of Limnology, The University of Wisconsin, Madison, WI 53706

85. Helen McCammon, Director, Ecological Research Division, Office of Health and Environmental Research, Department of Energy, Washington, DC 20545

86. W. A. Mills, Criteria and Standards Division, U.S. Environmental Protection Agency, 401 M. Street, S.W., Washington, DC 20460

87. D. R. Monti, Office of Technology Impacts, Division of Technology Assessments; Department of Energy, Washington, DC 20545

88. Christopher B. Nelson, U.S. Environmental Protection Agency, Office of Radiation Programs AW-461, 401 M Street, S.W., Washington, DC 20460 
89. H. T. Odum, Department of Environmental Engineering, University of Florida, Gainesville, FL 32601

90. W. S. Osburn, Division of Ecological Research, Department of Energy, Washington, DC 20545

91. J. J. Rigan, Office of the Governor, P. 0. Box 11156, Fernandez Juncos Station, Santurce, PR 00910

92. R. G. Schreckhise, Battelle-Pacific Northwest Laboratory, P.O. Box 999 , Richland, WA 99352

93. R. D. Shu17, Office of Technology Impacts, Division of Environmental Impacts, Department of Energy, Washington, DC 20545

94. D. Slade, Office of Health and Environmental Research, Department of Energy, Washington, DC 20545

95. Frank J. Swanburg, U.S. Nuclear Regulatory Commission, Washington, DC 20555

96. Jerry Swift, Technology and Assessments, Office of Radiation Programs, U.S. Environmental Protection Agency, 401 M. Street, S.W., Washington, DC 20460

97. Richard H. Waring, Department of Forest Science, Oregon State University, Corvallis, OR 97331

98. R. L. Watters, Office of Health and Environmental Research, Department of Energy, Washington, DC 20545

99. E. R. Williams, Office of Technology Impacts, Division of Policy Analysis, Department of Energy, Washington, DC 20545

100. J. H. Wilson, Jr., Office of Technology Impacts, Division of Environmental Impacts, Department of Energy, Washington, DC 20545

101-127. Technical Information Center, Oak Ridge, TN 37830 